Spring 2019

\title{
Petrology and Geochemistry of the Bearwallow Mountain Andesite, Mogollon-Datil Volcanic Field, New Mexico
}

Conor Lee O'Dowd

Missouri State University, ODowd1@live.missouristate.edu

As with any intellectual project, the content and views expressed in this thesis may be considered objectionable by some readers. However, this student-scholar's work has been judged to have academic value by the student's thesis committee members trained in the discipline. The content and views expressed in this thesis are those of the student-scholar and are not endorsed by Missouri State University, its Graduate College, or its employees.

\section{Follow this and additional works at: https://bearworks.missouristate.edu/theses}

Part of the Geochemistry Commons, Tectonics and Structure Commons, and the Volcanology Commons

\section{Recommended Citation}

O'Dowd, Conor Lee, "Petrology and Geochemistry of the Bearwallow Mountain Andesite, Mogollon-Datil Volcanic Field, New Mexico" (2019). MSU Graduate Theses. 3341.

https://bearworks.missouristate.edu/theses/3341

This article or document was made available through BearWorks, the institutional repository of Missouri State University. The work contained in it may be protected by copyright and require permission of the copyright holder for reuse or redistribution.

For more information, please contact BearWorks@library.missouristate.edu. 


\title{
PETROLOGY AND GEOCHEMISTRY OF THE BEARWALLOW MOUNTAIN ANDESITE, MOGOLLON-DATIL VOLCANIC FIELD, NEW MEXICO
}

\author{
A Master's Thesis \\ Presented to \\ The Graduate College of \\ Missouri State University \\ In Partial Fulfillment \\ Of the Requirements for the Degree \\ Master of Science, Geospatial Sciences
}

By

Conor Lee O’Dowd

May 2019 
Copyright 2019 by Conor Lee O’Dowd 


\title{
PETROLOGY AND GEOCHEMISTRY OF THE BEARWALLOW MOUNTAIN
}

\section{ANDESITE, MOGOLLON-DATIL VOLCANIC FIELD, NEW MEXICO}

Geography, Geology, and Planning

Missouri State University, May 2019

Master of Science

Conor Lee O’Dowd

\begin{abstract}
The Mogollon-Datil volcanic field (MDVF), located in southern New Mexico, is the result of episodic volcanism and the transition between arc and rift magmatism. The MDVF has been the focus of several mapping, stratigraphic, petrologic, geochronological, and geochemical studies to understand the complete volcanic and tectonic history. However, the majority of previous studies lack geochemical analyses on intermediate composition volcanic rocks, giving more attention to the large-volume ignimbrites and rhyolite flows as well as the minor basalt flows that occurred between 36 and $20 \mathrm{Ma}$. I present new whole-rock major- and trace-element analyses and petrographic textures on one of the largest volume intermediate composition formations in the MDVF, known as the Bearwallow Mountain Andesite. Geochemical analyses compiled from literature and original sources are used to assess arc- versus rift-related trends and give insight into the temporal variation in crustal thickness overtime. Based on these data, I propose a two stage model of assimilation and fractional crystallization (AFC) of a basaltic composition magma during the arc-rift transition in the Mogollon-Datil volcanic field. Induced partial melting of subduction-modified lithospheric mantle incorporates geochemical signatures from deep-seated rutile-bearing pyroxenite cumulates and likely assimilates amphibole-rich pre-30 Ma material. Fractional distillation and filter pressing removed crystal cargo within the melts, resulting in the crystal-poor Bearwallow Mountain Andesite. Crustal extension provides conduits for rapid magma ascent via dike propagation and is controlled by further AFC processes to produce a spectrum of compositions that make up the Bearwallow Mountain Andesite, ranging from basalt to andesite.
\end{abstract}

KEYWORDS: Andesite, Arc Magmatism, MDVF, New Mexico, Crustal Evolution. Magma Evolution 


\title{
PETROLOGY AND GEOCHEMISTRY OF THE BEARWALLOW MOUNTAIN ANDESITE, MOGOLLON-DATIL VOLCANIC FIELD, NEW MEXICO
}

\author{
By \\ Conor Lee O’Dowd

\begin{abstract}
A Master's Thesis
Submitted to the Graduate College

Of Missouri State University

In Partial Fulfillment of the Requirements

For the Degree of Master of Science, Geospatial Sciences
\end{abstract}

May 2019

Approved:

Gary S. Michelfelder, PhD., Thesis Committee Chair

Matthew McKay, PhD., Committee Member

Melida Gutierrez, PhD., Committee Member

Julie Masterson, Ph.D., Dean of the Graduate College

In the interest of academic freedom and the principle of free speech, approval of this thesis indicates the format is acceptable and meets the academic criteria for the discipline as determined by the faculty that constitute the thesis committee. The content and views expressed in this thesis are those of the student-scholar and are not endorsed by Missouri State University, its Graduate College, or its employees. 


\section{ACKNOWLEDGEMENTS}

The author would like to thank the faculty and staff of the Department of Geography, Geology and Planning at Missouri State University for their technical expertise and logistical support during this project. Also, thank you to Missouri State University students Brooke Benz, Brandie Oehring, Tyler Sundell, Mackenzie Wegmann, Evan Robertson, Jordan Cruzan, Daniel Quick, and Mary Humphreys for their assistance in the field and in the lab. Thank you to my thesis advisor, Gary Michelfelder, for developing my thesis project and assistance in the field, Thank you to Matthew McKay and Melida Gutierrez for their insight and comments on this paper. Additional lab support was provided by Frank Ramos at New Mexico State University, Kenny Horkely at the University of Iowa and the Peter Hooper Geoanalytical Lab at Washington State University. Funding for this project was provided by Missouri State University Graduate College and the Geological Society of America. 


\section{TABLE OF CONTENTS}

Overview

Page 1

Manuscript 1: Magmatism in the Mogollon-Datil Volcanic Field,

Page 4

Southern New Mexico, USA

Abstract

Introduction

Geologic Background

Regional Tectonic Setting of Western North America

Mid-Tertiary Volcanism in Western North America

Bimodal Magmatism of the MDVF

Analytical Methods

Results

Page 4

Page 4

Page 7

Page 7

Page 9

Page 14

Page 18

Page 19

Discussion

Page 21

Assessment of Arc versus Rift Geochemical Signatures

Page 21

Trace-Element Insight into Temporal Variation in Crustal

Thickness

Conclusion

Page 22

Page 26

References Cited

Page 28

Manuscript 2: Petrogenetic Evolution of Intermediate Magmas from the

Page 47

Mogollon-Datil Volcanic Field During Arc-Rift Transition: Insights from

Whole-Rock Geochemistry of the Bearwallow Mountain Andesite

Abstract

Introduction

Page 47

Page 47

Geologic Setting

Page 49

Methods

Sample Collection

Page 52

Page 52

Analytical Procedures

Page 52

Page 53

Field Relations of the Bearwallow Mountain Andesite

Page 53

Petrography and Mineral Chemistry

Page 54

Whole-Rock Major-Element Geochemistry

Page 55

Whole-Rock Trace-Element Geochemistry

Page 57

Discussion

Page 59

Origin of the Crystal-Poor Bearwallow Mountain Andesite

Page 59

Source Constraints of Bearwallow Mountain Andesite

Page 65

Magmas

Proposed Petrogenetic Model

Page 67

Conclusion

Page 69

References Cited

Page 72

Conclusions

Page 94

Full References Cited List

Page 98 


\section{LIST OF TABLES}

\section{Manuscript 2}

Table 1. Major- and trace-element compositions of the BWA Page 77

Table 2. Trace-element compositions of the BWA Page 80 


\section{LIST OF FIGURES}

\section{Manuscript 1}

Figure 1. Regional map of the extent of the MDVF

Page 37

Figure 2. Total-Alkali vs Silica diagram of the MDVF

Page 38

Figure 3. Major-element Harker diagrams for volcanic rocks in

Page 39

the MDVF combined with analyses from the NAVDAT

database

Figure 4. Rare-earth element diagrams of volcanic rocks in the

Page 40 MDVF

Figure 5. Regional bivariate trace-element plots of volcanic

Page 41

rocks in the MDVF

Figure 6. Dy/Dy ${ }^{*}$ versus $\mathrm{Dy} / \mathrm{Yb}_{\mathrm{N}}$ showing global arc systems and source reservoirs

Figure 7. Regional bivariate trace-element ratio plots with fractionation trends

Page 43

Figure 8. Regional bivariate trace-element plots of volcanic

Page 44

rocks in the MDVF

Figure 9. Calculated crustal thicknesses

Page 46

\section{Manuscript 2}

Figure 1. Regional map of the extent of the MDVF

Page 83

Figure 2. Photomicrographs of the BWA

Page 84

Figure 3. Total-Alkali vs Silica diagram for the BWA

Page 85

Figure 4. Major-element Harker diagrams for the BWA

Page 86

Figure 5. Rare-earth element and mulit-element log diagrams for the BWA

Page 87

Figure 6. Trace-element diagnostic diagrams for the BWA

Page 88

Figure 7. Trace-element Harker diagrams for the BWA

Page 89 
Figure 8. Trace-element mixing models

Page 90

Figure 9. FC and AFC trace-element modeling

Page 91

Figure 10. Evolution diagram for the BWA

Page 92 


\section{OVERVIEW}

The mid-Tertiary ignimbrite flare-up is a regional volcanic event that helped shaped the terrane of western North America. This burst of explosive silicic volcanism, first recognized by Lipman et al. (1972), is manifested in Nevada, Utah, Colorado, New Mexico, Arizona, and northwestern Mexico. The ancient continental arc system was a major time period of crustal growth and magma differentiation through melting and hybridization (Johnson, 1991). An estimated $\pm 500,000 \mathrm{~km}^{3}$ of ash-flow material erupted from caldera-forming magma systems that blanketed the interior of western North America (Best et al., 2016).

Studying the ignimbrite flare-up is a prime opportunity to further understand the geodynamic factors that control present day continental arc volcanism (de Silva et al., 2006). Many decades of field and laboratory work have established the stratigraphic framework of this regional event, in addition to numerous sample collections to provide insight to the magmatic source and petrogenesis of these eruptions (McIntosh et al., 1992; Davis and Hawkesworth, 1995). However, the complete volcanic record of this long-lived event has yet to be fully

resolved with respect to volume, age, and composition (Best et al. 2016). Many calderas have yet to be identified, thus pushing the need for further investigation. The peak of the ignimbrite flareup is also contemporaneous with a transition in tectonic regimes between the termination of subduction of the Farallon plate and the initiation of crustal extension (Lipman et al., 1972). This added complexity has made it challenging to accurately model the evolution of the magma storage systems that fueled these explosive eruptions. Several tecto-magmatic models have been proposed, although dispute over plate configuration and methods of magma generation has led to conflicting hypotheses. 
Here I present two journal article manuscripts on the history and evolution of the ignimbrite flare-up with a focus on the Mogollon-Datil volcanic field (MDVF). The first article, Magmatism in the Mogollon-Datil Volcanic Field, Southern New Mexico, USA, aims to reveal the complexity of the ignimbrite flare-up in terms of the regional tectonics and the petrogenetic processes that drove volcanism. In this article, attention is given to the diverse volcanic history of New Mexico with an emphasis on the MDVF where the style and composition of volcanic rocks vary from subduction- to rift-related volcanism. A review of existing tectonic and petrologic models will be assessed to understand the factors that control magmatism in southern New Mexico. Evaluation of current databases of compiled geochemical analyses from literature and original sources were used to examine geochemical trends and to assess the evolution of crustal thickness. This article lays the foundation necessary to understand the evolution of intermediate to mafic lava flows of the Bearwallow Mountain Andesite within the MDVF. Whole-rock geochemical datasets may suggest a change in crustal thickness as illustrated by low $\mathrm{Nb} / \mathrm{Ta},(\mathrm{La} / \mathrm{Yb})_{\mathrm{N}}, \mathrm{Sr} / \mathrm{Y}$ and $(\mathrm{Dy} / \mathrm{Yb})_{\mathrm{N}}$ ratios, with maximum thickness occurring during the start of the ignimbrite flare-up followed by crustal extension. Trace-element data support a predominately lithospheric mantle source for the majority of the ignimbrite flare-up with a transition to a more asthenosphere-derived composition during later Rio Grande rift-related basaltic volcanism.

The second article, Petrogenetic Evolution of Intermediate Magmas from the MogollonDatil Volcanic Field During Arc-Rift Transition: Insights from Whole-Rock Geochemistry of the Bearwallow Mountain Andesite, focuses on the largest intermediate composition formation in the MDVF, the Bearwallow Mountain Andesite (BWA), in an effort to understand the petrogenesis of intermediate composition lava flows in the MDVF, and the tectonic conditions which allowed 
the transition from rhyolite to basaltic andesite between $28 \mathrm{Ma}$ and $23 \mathrm{Ma}$. Previous studies of MDVF volcanic rocks focused on the large-volume ignimbrites and rhyolite flows and the minor basalt flows that occurred between 36 and $20 \mathrm{Ma}$, thus establishing an inherent bimodal trend. The petrogenesis of intermediate composition volcanic suites, however, is still unclear. Therefore, whole-rock major- and trace-element geochemistry and petrography of the BWA is used to evaluate two questions: 1) What is the geochemical diversity of the BWA? 2) What petrogenetic process(es) and magmatic source produced the crystal-poor intermediate composition lava flows of the BWA? In this article, different magmatic scenarios are tested through geochemical modeling to determine the appropriate petrogenesis. Petrography, wholerock major- and trace-element concentrations, and petrologic modeling methods provide evidence that the BWA was likely erupted from a subduction-modified lithospheric mantle source that was contaminated by pre-30 Ma material through assimilation and fractional crystallization processes and rapidly ascended to the Earth's surface via deep conduits/fractures. 


\title{
MANUSCRIPT 1: MAGMATISM IN THE MOGOLLON-DATIL VOLCANIC FIELD, SOUTHWESTERN NEW MEXICO, USA
}

\begin{abstract}
The Mogollon-Datil volcanic field (MDVF) in southern New Mexico is the result of punctuated volcanism and the transition between arc and rift magmatism. The distinct style of arc volcanism in the MDVF contrasts significantly with the "normal" steady-state model, in which volcanism occurred far inland beneath a flat subducting slab that rolled back to a steeper dip. During the mid-Tertiary ( $\sim 50 \mathrm{Ma})$, this initiated large-scale MASH zones to develop in the lower to upper crust of western North America, induced by upwelling of basaltic magma. This fueled what is known as the "ignimbrite flare-up" at $~ 36 \mathrm{Ma}$ in the MDVF. During mid- to late-Oligocene, the tectonic stress regime relaxed, initiating intercontinental extension, resulting in a rapid shift in the style and composition of volcanism to a more basaltic composition effusive volcanic field. Evaluation of current databases of compiled geochemical analyses from literature and original sources are used to examine geochemical trends and to assess the evolution of crustal thickness during the arc-rift transition. Whole-rock geochemistry is interpreted from volcanic rocks spanning four regionally extensive volcanic units/phases in southern New Mexico: Rubio Peak Formation (45-36 Ma); Bell Top Formation and rhyolitic flows (36- $28 \mathrm{Ma})$; Uvas Basalts (28-24 $\mathrm{Ma}$ ); and the Bearwallow Mountain Andesite (26-23 Ma). Geochemical variations suggest a change in crustal thickness as illustrated by low $\mathrm{Nb} / \mathrm{Ta},(\mathrm{La} / \mathrm{Yb})_{\mathrm{N}}, \mathrm{Sr} / \mathrm{Y}$ and $(\mathrm{Dy} / \mathrm{Yb})_{\mathrm{N}}$ ratios, with maximum thickness during the start of the ignimbrite flare-up followed by crustal extension. Trace-element data support a predominately lithospheric mantle source for the majority of the ignimbrite flare-up and associated intermediate lava flows with a transition to a more asthenosphere-derived composition during later Rio Grande rift-related basaltic volcanism.
\end{abstract}

\section{Introduction}

The origin of Eocene to Oligocene volcanism in western North America is controversial with respect to understanding the source, regional extent, duration, and evolution of magmatism (Lipman et al., 1972; Lipman, 1980, 2007; Davis et al., 1993; Elston, 2008; Best et al., 2016). Large portions of western North America is characterized by late-Cenozoic arc magmatism, episodic ignimbrite flare-ups, and rift-related bimodal volcanism, with tectonic regime playing an essential role in the generation, composition, and ascent of magma (Cather, 1990). Silicic to intermediate volcanic rocks, typically associated with arc magmatic systems, result in 
differentiation of subduction-modified mantle sources and subsequent induced partial melting of crustal material (McMillan et al., 2000; Kent, 2016). However, the distinct style of arc volcanism in western North America contrasts significantly with the "normal" steady-state model (Straub et al., 2015). Instead, volcanism occurs far inland, up to $1000 \mathrm{~km}$ within the North American plate as a result of flat slab subduction that rolls back to a steeper dip (Best et al., 2016).

Peak volcanism in western North America is thought to be contemporaneous with a regional-scale transition in tectonic regimes from crustal shortening to intercontinental extension (McMillan, 1998). The style and composition of volcanism shifts from calc-alkaline, silicicintermediate rocks to more ocean island basalt-like (OIB) composition rocks. It is widely accepted that the end of subduction along the East Pacific margin and initiation of extension influenced the shift in volcanism (Lipman et al., 1972; Chapin et al., 2004), but several tectomagmatic models exist to explain the dynamic processes driving this change in volcanism (Fodor, 1975; Coney, 1978; Lipman, 1980; Wernicke et al., 1987; Cather, 1990; Davis et al., 1993; Davis and Hawkesworth, 1994; Humphreys, 1995; Chamberlin et al., 2002; Chamberlin et al., 2004; English et al., 2003; Farmer et al., 2007; McQuarrie and Oskin, 2010; Christiansen and Best, 2014; Best et al., 2016). The complexity and behavior of magma storage systems present a difficult challenge in resolving variability in magma composition and volcanic history. Previous studies attempt to subdivide magmatic activity in western North America, but, conflicting interpretations have led to ambiguous classification (Lipman et al., 1972; Elston et al., 1973; Fodor, 1975; Davis et al., 1993; Davis and Hawkesworth, 1993, 1994, 1995). The petrologic and geochemical boundaries set forth to temporally categorize rock suites often overlap or do not conform to an agreed upon subgrouping (Elston et al., 1973; Davis and Hawkesworth, 1994). 
The Mogollon-Datil volcanic field (MDVF) has been an area of interest for numerous petrological and geochemical studies. It consists of caldera-forming ignimbrites, bimodal lava flows and domes, and intermediate to mafic composition cinder cones that stretch across New Mexico and eastern Arizona. The complex volcanic history of the MDVF is further complicated by overprint of magmas from the Basin and Range province, Rio Grande rift, Jemez lineament, Colorado Plateau, Southern Rocky Mountains, Great Plains, and the Rocky Mountain alkali province (Chapin et al., 2004). Each of these geologic terranes imparts a unique signature that contributes to the change in style and composition of volcanism that was present before, during, and after the ignimbrite flare-up.

Unlike other ignimbrite-forming arc systems, the variability in rock suites within the MDVF is not fully explained by current petrogenetic models (i.e. MASH and/or thermal "hot zone"). A regional Bouguer gravity anomaly low of $\sim 40 \mathrm{mGals}$ and an aeromagnetic high has been interpreted to be the regional batholith that likely fueled volcanism (Ratté et al., 1984). However, a lack of further geophysical evidence (i.e. seismic surveys) has made it difficult to interpret the plutonic record of the MDVF.

In this paper, 1) review the tectonic and petrologic models controlling magmatism in southern New Mexico; 2) assess geochemical trends using up-to-date databases of high-quality geochemical analyses compiled from literature and original sources; and 3) examine geochemical variation of trace-elements, temporally and spatially, to determine the evidence of source and influence of crustal thickness on magma chemistry. Geochemical data from basalt through rhyolitic composition volcanic rocks erupted between 45-20 Ma are presented, as well as comparing geochemical variations at a variety of scales. The geographic location of the study area is restricted to the state of New Mexico border, south of $35^{\circ} \mathrm{N}$ latitude and west of $106.5^{\circ} \mathrm{W}$ 
latitude (Fig. 1). The review of tectonic models are restricted to models proposed which include the Mogollon-Datil volcanic field. To examine the tectonic and volcanic evolution of southern New Mexico, we use a database of volcanic rocks erupted at MDVF calderas, cinder cones and eroded stratocones compiled from published sources. We supplement these data with new majorand trace-element data, and U-Pb zircon geochronology.

\section{Geologic Background}

Regional Tectonic Setting of Western North America. The tectonic history of western North America can be divided into three main periods: crustal shortening, compressive/neutral stress transition, and extension (McMillan, 1998). During the late Cretaceous (80-66 Ma), a convergent plate boundary developed along the southwestern margin of North America with the Farallon plate subducting at a low angle beneath the North American plate (McQuarrie and Wernicke, 2005). Flat-slab subduction of the oceanic plate was likely caused by buoyancy effects of thick crust (i.e. commonly found in oceanic plateaus). Prolonged subduction of the sub-horizontal slab cooled the thermal structure of the oceanic lithosphere to a point where phase transitions were delayed (i.e. basalt to eclogite). This allowed the slab to further penetrate beneath the North American plate (Gutscher et al., 2000), triggering the Laramide orogeny within the western interior of North America. Resultant compressional stresses established basement-cored uplifts and associated crustal shortening in the foreland (English et al., 2003;

Best et al. 2016). As the Pacific spreading center approached North America, the subducting Farallon plate began to steepen within the interior of the continent. This was thought to be due to a slowing rate of convergence from 11-14 cm/yr to 6-9 cm/yr (Severinghaus and Atwater, 1990; Chapin et al., 2004). The oceanic plate rolled back and eventually broke apart into the 
asthenosphere (Sigloch, et al., 2008; Humphreys, 2009). The rollback and subsequent delamination of the Farallon plate was thought to have terminated slab-pull (Carlson et al., 1983; Elston, 2008).

The end of Laramide deformation during the late Eocene marked a change in tectonic stresses from compressional to extensional. This transition of lithospheric stress initiated the Rio Grande rift and Basin and Range Province (Menard, 1978; Cather, 1990). Extension was thought to have resulted from changes in the relative motion of the Farallon and North American plate, as well as gravity spreading of the thickened continental crust (Werkicke et al., 1987). During crustal extension, the formation of the Rio Grande rift unzipped from the south starting in northern Mexico, through southern New Mexico, and extended up to Leadville, Colorado (Baldridge et al., 1995; McMillan, 1998). The Rio Grande rift established a series of continues deep grabens and half grabens as a result of a re-orientation of the principle stress direction (Cather, 1990; McMillan, 1998; Chapin et al., 2004). As extension migrated from southwest to northwest, early stages (29-20 Ma) were characterized by low-angle listric normal faulting with high strain rates. Later stages of extension ( $\sim 20 \mathrm{Ma})$ changed from ductile to brittle, followed by high-angle block faulting that formed the modern Basin and Range Province (Cameron et. al 1989; Davis and Hawkesworth, 1995; McMillan, 1998; Elston, 2008).

The exact timing and duration of extension is not clearly constrained due the diachronous characteristic of the rift zone, and thus, is still a matter of debate (Cather, 1990; Mack, 2004). Precise dates vary considerably, but it is generally accepted that extension initiated between 3228 Ma (Chapin and Seager, 1975; Henry and Price 1986; Davis et al., 1993; Chamberlin et al., 2004; Elston, 2008). Studies have also suggested the transition between compressional/neutral stresses began as late as $35 \mathrm{Ma}$ (Mack, 2004), while others have extended the range between 36- 
$28 \mathrm{Ma}$ (Michelfelder and McMillan, 2012). Thermochronology, structural analysis, and the stratigraphic record suggest large-scale extension didn't take effect until after $23 \mathrm{Ma}$ (Smith et al., 1991; Armstrong et al., 2003; McQuarrie and Wernicke, 2005; Colgan and Henry, 2009; Henry et al., 2011; Anderson et al., 2013).

Mid-Tertiary Volcanism in Western North America. During the mid-Tertiary, southwestern North America was characterized by westerly migrating large-scale explosive silicic eruptions of the "ignimbrite flare-up" (Coney, 1978) accompanied by discontinuous lava flows. This flare-up, consisting of nearly $500,000 \mathrm{~km}^{3}$ of silicic magma, was prevalent in the Sierra Madre Occidental province, and in the Mogollon-Datil, Southern Rocky Mountain, Great Basin, and Challis volcanic fields (Best et al., 2016). The style of volcanism and magma composition during this prolonged event changed significantly overtime. It is postulated that these large volumes of accumulated magma coincided with a transition from the destructive convergent margin to a transform boundary, leading to plate-interior volcanic suites (Atwater, 1970, 1989; Coney, 1972; Lipman et al., 1972; Cather, 1990; Severinghaus and Atwater, 1990; Elston, 2008).

The generation and transport of magma to the Earth's surface during the end of subduction and subsequent crustal extension in southern New Mexico is poorly understood. Several tecto-magmatic models are presented to explain the processes responsible for triggering volcanism, however, the relative roles of the continental lithosphere, oceanic plate, and the mantle as magmatic sources remain unclear (Best and Christiansen, 1991; Humphreys, 1995; McMillan et al., 2000). In addition, models do not adequately explain the compositional variation of all the rock suites (e.g. from silicic-intermediate ignimbrites to basaltic andesites and true basalts). Lipman et al. (1972) was one of the first to correlate variations in Cenozoic 
volcanism with temporal and spatial changes in tectonic styles in western America. Proceeding studies further support this notion that the mantle source triggering magmatic activity relates to the structural change in tectonic environments (McMillan, 1998; Elston, 2008, Best and Christiansen, 2013). However, there remains considerable debate over the extent to which magmatism is affected by the change in plate configuration (e.g. subduction- and/or extensionrelated processes, crustal thickness, etc.; Wernicke et al., 1987; Davis and Hawkesworth, 1994; Chamberlin, 2002, 2004). Furthermore, the physical conditions of magma storage, magma remobilization, and reservoir timescales remain poorly constrained (Cooper and Kent, 2014; Rentz et al., 2019).

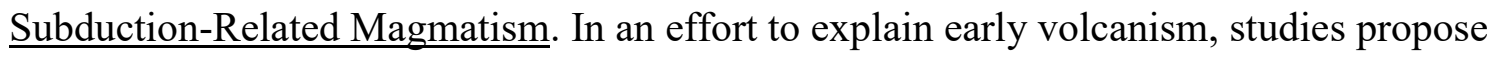
subduction-related processes as the probable cause of magmatic activity. The thermal and mechanical evolution of the Farallon plate undergoing flat slab subduction is thought to have controlled the style of volcanism (Coney, 1978; Lipman, 1980; Best and Christiansen, 1991). It is widely accepted that large volumes of basaltic magma, derived from fluid fluxing of the mantle wedge, provides heat to generate silicic to intermediate melts in the upper crust (Best et al. 2016). Thus, subduction-modified lithospheric mantle (e.g. low $\mathrm{Nb} / \mathrm{Ba}$ and $\mathrm{Ta} / \mathrm{Ba}$ ratios and $\varepsilon N d$ near +1 ) from the down-going oceanic plate may have contributed to the development of the widespread ignimbrite flare-up and associated calc-alkaline andesitic to dacitic magma series (Lipman et al., 1972; McMillan, 1998; Best et al., 2016).

Lipman (1980) attributed magmatism to the rollback of the Farallon slab as a reasonable mechanism to produce caldera-forming ignimbrites. During the approach of the Pacific spreading center, termination of subduction and suggested removal of the Farallon plate exposed the upper lithosphere with the underlying asthenosphere. Upwelling of asthenospheric mantle from slab 
rollback or buckling (Humphrey, 1995) would have triggered adiabatic decompression partial melting in the overlying lithosphere. This rollback event and subsequent tearing of the subducted slab was thought to have generated enough heat to initiate explosive ignimbrite eruptions (Atwater, 1989; Chamberlin, 2002; Elston, 2008). In response to slab removal, a large influx of basaltic melt from the ruptured oceanic plate accumulated in the upper lithosphere. These large volumes of basaltic melts weakened the surrounding crust generating what is recently referred to as a MASH/hot zone (Hildreth and Moorbath, 1988; Annen et al., 2006). Building upon concepts of basalt differentiation, and aspects of assimilation and fractional crystallization (AFC; DePaolo et al., 1981), these recently proposed magma mush (crystal-rich) models explain the hybridization between parental magmas and crustal material through melting, assimilation, storage, and homogenization (Hidlreth and Moorbath, 1988; Annen et al., 2006). The suggested regional-scale basaltic magma beneath southwestern America induced partial melting and homogenized with lower crustal rock before rising by fractional crystallization. As a result of compressional stresses during this time, magma transport via dike propagation was likely hindered. Thus, Eichelberger (1978, 1980), and later supported by Cather (1990) and Chamberlin (2002), proposed that the evolving intermediate magmas ascended to the upper crust as rising diapirs and expanded laterally to form discoidal reservoirs. Upon eruption, the evolved magma would have worked its way towards the surface through a network of steps to produce a range of silica-rich rock suites. The geochemical signature of these siliceous rocks (dacites and rhyolites) typically show depletion in high field strength elements and high $\mathrm{Ba} / \mathrm{Nb}$, reflecting their subduction inheritance (Best et al., 2016). To support this model, Farmer et al., (2007) estimated mantle source volumes and concluded that removal of the shallowly subducting slab would have produced sufficient magma to satisfy ignimbrite flare-up conditions. Chamberlin (2002) further 
added that sequentially rising mantle plumes may have been influenced by a westward flow of asthenosphere, thought to be initiated by contemporaneous extension, generating the apparent westward migration of magmatism. McQuarrie and Oskin (2010) later attributed this pattern of migrating volcanism as a result of non-uniform tearing of the subducted slab as it rolled back beneath the continental plate.

Non-Subduction Related Magmatism. Alternative thermal and petrogenetic models have shown the flat slab subduction of the Farallon plate may not have had a direct influence on early Tertiary volcanism. Mutschler et al. (1987) proposed local intraplate deformation of deep continental lithosphere rather than rollback of the Farallon plate. English (2003) examined lowangle subduction models to test the viability of slab rollback. The idea of flat slab subduction is still controversial and is typically associated with magmatic gaps. English (2003) concluded that large-volume arc magmatism would be problematic due to a cold thermal regime $\left(500-700^{\circ} \mathrm{C}\right)$ and pointed to the need for an alternative mechanism. The low-angle subducted slab would have cooled the base of the lithosphere, insulating it from convecting asthenospheric heat. Usui et al. (2003) analyzed well preserved eclogite xenoliths from fragments of the subducting Farallon plate and suggested that the slab was partly dewatered during the flat slab stage. Thus, the subducting slab would be anhydrous before descending into the asthenosphere, resulting in reduced magma generation.

Extension-Related Magmatism. Other models have suggested lithospheric extension as the primary mechanism of magma generation or a combination of extension with rollback of the Farallon plate as a way of explaining intraplate magmatism in western North America. Questions these models address involve the timing of extension, either before, during, or after the ignimbrite flare-up, and whether extension provoked decompression melting of the sub- 
lithospheric mantle (McKenzie and Bickle, 1988; McKenzie,1989; Leeman and Harry, 1993), or by inducing melting of mafic portions of the continental lithospheric mantle (Leeman and Harry, 1993).

Gibson et al. (1992) analyzed changes in isotope and trace-element ratios and concluded that early magmatism was not directly related to the subduction of the Farallon plate, but rather to lithospheric extension. Based on geochemical trends of Oligocene trachybasalt, Chamberlin et al. (2004) supported this notion and argued against subduction-related processes as a viable explanation of mid-Tertiary volcanism. However, the depleted $\mathrm{Nd}$ isotopic signature of the trachybasalt and Y-poor rhyolites during the end of subduction still suggested a geochemical tie to subduction-related processes (Chamberlin, 2004). Christiansen and Best (1991) argued that flat slab subduction would not have generated enough magma from the mantle lithosphere alone to produce the large-scale ignimbrite flare-up and suggested that lithospheric extension may have aided magma generation. McMillan (1998) and Elston (2008) expanded on this notion stating that early crustal extension (40-20 Ma) likely helped initiate the ignimbrite flare-up during a passive continental setting. It was suggested that melt production may have resulted in local areas of tensional stress superimposed upon a weakly compressional stress field. Progressing to a more extensional tectonic regime, the weakened state of the lithosphere would enable dike propagation to be the predominant mechanism to allow basaltic melts to penetrate the crust (Perry et al., 1987, 1988; Cather, 1990; Chamberlin at al. 2002). During the ascent of primitive magma by fractionally crystallization, induced partial melting would have allowed evolved silicic melts to form (Elston, 2008). In contrast to earlier interpretations (Davis and Hawkesworth, 1995; Cather, 1990; Chamberlin, 2002), studies within the Great Basin province argued against significant regional extension during the ignimbrite flare-up. Best et al. 
(2016), and Ducea and Barton (2007) suggested that regional extension followed the $36-18 \mathrm{Ma}$ ignimbrite flare-up, thus not contributing to the rhyolitic and andesitic rock suites. Farmer et al. (2007) also suggested lithospheric extension may not have played a significant role due to the absence of crustal extension during magmatism in the San Juan volcanic field.

After $\sim 20 \mathrm{Ma}$, once the ignimbrite flare-up ceased, the lithosphere cooled and extension changed from ductile to brittle deformation. It is agreed upon by most studies that a second thermal regime developed during this time period, resulting in brittle extension to form the Rio Grande rift and Basin and Range Province. During the Pliocene, Elston (2008) suggested basaltic magma rose from local pockets in the upper mantle, tapped by extensional fissures. Volcanism transitioned from $\mathrm{Fe}$-rich basaltic andesites to true basalts with high $\mathrm{Nb} / \mathrm{Ba}$ and $\mathrm{Ta} / \mathrm{Ba}$ ratios and high positive $\varepsilon N d$ values between +7 and +4 (McMillan, 1998). Melt zones derived from an OIB-modified lithosphere (McMillan, 1998) and yielded tholeiitic and alkali basalts (Fodor, 1975; Bornhorst, 1980, 1988; Davis and Hawkesworth, 1993; Davis et al., 1993).

Bimodal Magmatism of the MDVF. The Mogollon-Datil volcanic field (MDVF) was the center of active volcanism during the mid-Tertiary, spanning $40,000 \mathrm{~km}^{2}$ in southern New Mexico (Fig. 1; Ratté et al. 1984; Elston, 1989; Davis and Hawkesworth, 1993). The MDVF is part of a discontinuous belt of silicic volcanic fields extending from the San Juan Mountains in Colorado into central Mexico (McIntosh et al., 1992). The MDVF contains an estimated 10,000 $\mathrm{km}^{3}$ (Elston, 2008) of volcanic rocks and is located within the southern portion of the Basin and Range Province along the southwestern margin of the Colorado Plateau (Bikerman at al., 1990). The MDFV is suggested to have been associated with a number of other active volcanic fields during the mid-Tertiary, such as the San Juan, High Plateau, and the White Mountains (Davis and Hawkesworth, 1994). 
The MDVF was a result of punctuated volcanism, predominately intermediate composition volcanic rocks (Farmer et al., 2007), between 40 and $20 \mathrm{Ma}$ (Davis and Hawkesworth, 1994). Magmatic activity began around the time subduction of the Farallon plate ended ( $\sim 37 \mathrm{Ma})$ and during the initiation of crustal extension (Davis and Hawkesworth, 1995). Based on geochemical and geochronological studies, magmatic activity was limited to several episodic pulses of caldera-forming ash flow eruptions (ignimbrites) in late Oligocene to early Miocene with discontinuous sequences of andesitic to basaltic volcanism (McIntosh et al., 1992). The magmatic processes operating in the plumbing system beneath the MDFV have yet to be fully understood.

Volcanic activity began 40-37.6 Ma within the eastern and southern areas of the MDVF producing the Rubio Peak and Palm Park formation (McMillan, 1998; Chapin et al., 2004). The volcanic rocks comprised of calc-alkaline andesites and dacites with an arc-like composition. Volcanism transitioned into bimodal rhyolite ignimbrite eruptions with intercalated mafic lavas creating the Bell Top Formation 36.2-28.6 Ma (McIntosh et al., 1992; McMillan, 1998). Based on ${ }^{40} \mathrm{Ar} /{ }^{39} \mathrm{Ar}$ age distributions, regional ignimbrites in the MDVF can be broadly categorized into four distinct eruptive events: First Flare-up (36.2 to $33.5 \mathrm{Ma}$ ), Short Burst (32.1 to 31.4 Ma), Big Doublet (29.0 to $27.4 \mathrm{Ma}$ ), and Last Gasps (26.1 to $24.3 \mathrm{Ma}$ ). The first flare-up pulse primarily consisted of low silica rhyolites making up 11 known outflow sheets and several smaller units. The larger units during this event included the Kneeling Nun Tuff (34.9 Ma) and the Box Canyon Tuff (33.5 Ma). The second pulse of ignimbrite volcanism consisted of three regional outflow sheets: Hells Mesa Tuff (32.1 Ma), Blanco Tuff (31.6 Ma), and Tadpole Ridge (31.4 Ma). The third and largest pulse of ignimbrite activity produced nine major regional ignimbrites. These large-scale ash flows were tied to the Bursum Caldera, about $45 \mathrm{~km}$ in diameter (Ratté et 
al., 1984; McIntosh et al., 1992) and can be spatially broken up into a northern and southern cluster of calderas (McIntosh, 1992). Within the southwestern part of the MDVF, the Davis Canyon Tuff (29.0 Ma), the Shelley Peak Tuff (28.1 Ma), the Bloodgood Canyon Tuff (28.1 Ma), and the Apache Springs Tuff (27.9 Ma), are exposed in the Black Range. The northern region of the MDVF produced the La Jencia Tuff (28.9), the Vicks Peak Tuff (28.5 Ma), the tuffs of Caronita Canyon (28.0 Ma), the Lemitar Tuff (28.0 Ma), and the South Canyon Tuff (27.4 Ma). The final and youngest pulse produced the Tuff of Slash Ranch (26.1 Ma) and the Tuff of Turkey Springs (24.3 Ma; McIntosh, 1992).

Intermediate-Composition Volcanics in the MDVF. Ignimbrite flare-ups within the MDFV have been the center of attention of scientific study, leaving out the ubiquitous andesite to basaltic andesite lava flows. Comprehensive studies on these intermediate composition rock suites are lacking and have yet to be fully integrated into the volcanic history of the MDVF.

Mid-Tertiary volcanism consisted of three broadly andesitic lava sequences: $38-34 \mathrm{Ma}$ (T2), 31-29 Ma (T3a), and 25-20 Ma (T4a; Elston, 1989; Davis et al., 1993). These andesitic lavas erupted from small shield/stratovolcanoes (Elston et al., 1976). The early andesitic lavas, 38-34 Ma, were characterized by a range in composition from basaltic andesite through rhyodacite. Andesites were the dominate rock type and are strongly porphyritic with a mineral assemblage consisting of plagioclase, augite, and hydrous ferromagnesian minerals in a trachyitic groundmass (Davis and Hawkesworth, 1993). The 31-29 Ma sequence was more mafic in composition with the majority of the distribution skewed towards basaltic andesite. The rocks tend to be aphyric and more vesicular with an anhydrous mineral assemblage of olivine, augite, and plagioclase in an intergranular groundmass (Davis and Hawkesworth, 1993). The lateTertiary group, 25-20 Ma, was a volumetrically minor sequence of olivine and alkali basalt 
$\left(<52 \% \mathrm{SiO}_{2}\right)$, rich in olivine and augite, with plagioclase mainly confined to the groundmass (Davis et al., 1993).

$\underline{\text { Rubio Peak Formation. Folded rocks associated with Laramide shortening are }}$ unconformably overlain by a suite of calc-alkaline andesite to dacite volcanic rocks including: lava flows, beccias, and low-volume ash-flow tuffs. These volcanic rocks range in age from 4537.6 Ma and initiate the volcanic activity of the MDVF. Rubio Peak rocks are broadly "arc-like" in composition and are dominated by plagioclase and hornblende-bearing, high-K andesites ranging in $\mathrm{SiO}_{2}$ from 58-62 wt\%. Incompatible trace-element ratios and concentrations reveal arc signatures and patterns (high $\mathrm{Ba} / \mathrm{Nb}, \mathrm{Ba} / \mathrm{Ta}, \mathrm{Ba} / \mathrm{La}$ and $\mathrm{La} / \mathrm{Ta}$ ratios), moderate ${ }^{87} \mathrm{Sr} /{ }^{86} \mathrm{Sr}$ ratios, moderate negative $\varepsilon N d$ values and $\mathrm{Pb}$ isotope ratios between the radiogenic signatures of rhyolite tuffs and the non-radiogenic values of the Uvas andesites and basalts (McMillan et al., 2000). Basalts associated with the Rubio Peak volcanic rocks are only found at the top of the section or as dikes. $\mathrm{K} /$ Ar dates of these basalts also indicate that mafic lavas were erupted only late in the Rubio Peak interval (McIntosh et al., 1992).

Bearwallow Mountain Andesite. The BWA is a chemically distinct series of 30-20 Ma andesites and basaltic andesites (Davis and Hawkesworth, 1993) which make up the T4a and upper part of the Ta3 sequences (Davis, 1991; Davis et al., 1993). The T4a lavas are the dominate group during this time interval and are located throughout the central and northern regions of the MDVF. The volcanic centers of this group (Elk Mountain, O-Bar-O Mountain, Pelona Mountain, and Luera Peak) form the peaks of the Mogollon, Tularosa and Mangas Mountains. The stratocone-related T4a basaltic andesites and andesites are referred to as the Bearwallow Mountain Formation (Elston et al., 1976), but later re-defined as the Bearwallow Mountain Andesite (BWA; Marvin et al., 1987). Previous studies (Fodor, 1975; Bornhorst 1980) 
have shown variable degree in differentiation within this rock group and thus, the classification of solely andesitic may not fully represent the compositional range. The BWA marks the end of Oligocene volcanism in which a $\sim 7$ Ma hiatus takes place until volcanism picks back up during mid-Miocene.

Major- and trace-element contents of the BWA suggest a high-K calc-alkaline association. The low silica andesites are characterized by small amounts of olivine (iddingsite), and augite phenocrysts in a plagioclase and augite groundmass. The more evolved andesites from the BWA contain phenocrysts of plagioclase, enstatite, and augite, with little to no olivine in a plagioclase, pyroxene, and glass groundmass. Trace-element concentrations show low Ba-Nb and $\mathrm{Zr} / \mathrm{Nb}$ as a result of their higher high field strength elements (HFSE; Nb, Ta, and Ti). The younger members of this group are also suggested to show chemical affinity with the Post-20 Ma group (Davis et al., 1993). The basaltic andesites have ${ }^{87} \mathrm{Sr} /{ }^{86} \mathrm{Sr}$ in the range $0.7065-0.7074$ and ${ }^{143} \mathrm{Nd} /{ }^{144} \mathrm{Nd}$ in the range $0.51221-0.51243$ (Davis and Hawkesworth, 1993).

\section{Analytical Methods}

20 rock samples of one to two $\mathrm{kg}$ were collected from distinct lava flows and tuffs distributed across the entire field area. Major-element oxide and trace-element ( $\mathrm{Sc}, \mathrm{V}, \mathrm{Cr}, \mathrm{Ni}, \mathrm{Zn}$, $\mathrm{Rb}, \mathrm{Sr}, \mathrm{Y}, \mathrm{Zr}, \mathrm{Nb}, \mathrm{Ba}, \mathrm{Pb}$, and $\mathrm{Th}$ ) analyses were obtained by standard X-ray fluorescence (XRF) spectrometry at Washington State University's Peter Hooper GeoAnalytical Laboratory, Pullman, Washington, using a ThermoARL Advant'XP + sequential X-ray fluorescence spectrometer using the methods described in Johnson et al. (1999). Estimated $2 \sigma$ precision is better than $1 \%$ for most elements except $\mathrm{Y}, \mathrm{Nb}$, and $\mathrm{Cr}$ (better than 5\%). Analysis of traceelement contents, including the rare-earth elements (REE), were performed on 20 samples by 
inductively coupled plasma-mass spectrometry (ICP-MS) at Washington State University's Peter Hooper GeoAnalytical Laboratory using an Agilent Technologies 7700 ICP-MS following the protocol of Jarvis (1988) and Johnson et al. (1999). The analytical precision for the method at WSU is better than 5\% (RSD) for the REEs and 10\% for the remaining trace-elements. Analyses of USGS and international standards and comparison of trace-element data for $\mathrm{Y}$, and $\mathrm{Nb}$ from XRF show good agreement with consensus values and XRF data.

\section{Results}

In this study we examine and interpret geochemical data from volcanic rocks throughout southern New Mexico that are between 45 and $20 \mathrm{Ma}$. We use and interpret data from volcanic rocks spanning four regionally extensive major volcanic units/phases in southern New Mexico: Rubio Peak Formation (45-36 Ma); Bell Top Formation and rhyolitic flows (36- $28 \mathrm{Ma}$ ); Uvas Basalts (28-24 Ma); and the Bearwallow Mountain Andesite (26-23 Ma; McMillan et al., 2000). We compare volcanic rocks within these units to each other in order to assess location and migration of the arc front, but primarily focusing on comparing the trends observed within a limited range of $\mathrm{SiO}_{2}$ content (45-55 wt\% and 55-65 wt\%) and a restricted spatial range (longitude between $108^{\circ}$ to $109^{\circ} \mathrm{W}$; latitude between $32^{\circ}$ and $34^{\circ} \mathrm{N}$ ). We restrict the type of material evaluated to lava flows, domes, dikes and sills. The data presented meets the criteria listed above as well as span the range of expected volcanic activity in the southern New Mexico volcanic arc with limited along-arc variations in order to minimize the potential variation in magma source, mantle composition, and variation in magmatic processes along the arc front. While we would have liked to have focused our examination on single volcanic centers or fields in the study area, this was not possible due to the limited dataset currently available. New data in 
this study is presented below and combined with published data to fill some of the gaps of previously published work.

Lava types analyzed and interpreted in this study are mostly basaltic andesite and andesites along with a small number of traditional basalts. Intrusive dikes and domes analyzed and interpreted include trachybasalts, and andesites with a few basaltic trachyandesites and memenites. The vast majority of samples plot as high-K, calc-alkaline trends (Fig. 2, 3). However, some lava flows with lower $\mathrm{SiO}_{2}$ are lower $\mathrm{K}$ content rocks.

All studied MDVF volcanic and intrusive rocks exhibit typical and relatively uniform arc signatures characterized by a marked enrichment in $\mathrm{Rb}, \mathrm{Zr}, \mathrm{Ba}, \mathrm{K}$, and $\mathrm{Th}$, combined with marked depletion in $\mathrm{Lu}, \mathrm{Eu}, \mathrm{Ni}, \mathrm{Y}$, and Ti. Eu anomalies decrease over time with values near one within the basaltic andesites and basalts (Fig. 4a). $\mathrm{Nb}$ /Ta ratios are lowest in the more evolved rhyolites and dacites (11-14) and reach the highest values within the andesites and basaltic andesites (16-19; Fig. 4b). Nb/Ta ratios drop to mantle values within the basalts (15-16). $\mathrm{Nb}$ and Ta concentrations show a broad decrease with increasing Mg\# (Fig. 4c, 4d).

REE patterns (Fig. 5) were evaluated using $(\mathrm{La} / \mathrm{Tb})_{\mathrm{N}}$, and $\mathrm{Dy} / \mathrm{Yb}_{\mathrm{N}}$ ratios as well as traceelement ratios $\mathrm{Nb} / \mathrm{Ta}$ and $\mathrm{Sr} / \mathrm{Y}$ to distinguish age groups (Fig. 6). $\mathrm{Sr} / \mathrm{Y}$ generally decreases with increasing $\mathrm{Y}$, with maximum ratios of $\mathrm{Sr} / \mathrm{Y}$ observed in the $24-28 \mathrm{Ma}$ rocks. ( $\mathrm{La} / \mathrm{Tb})_{\mathrm{N}}$ shows a fairly similar trend with a general decrease with increasing $\mathrm{Yb}$. $\mathrm{Nb} / \mathrm{Ta}$ ratios show an increase with $\mathrm{Dy} / \mathrm{Yb}_{\mathrm{N}}$ ratios, suggesting a transition in fractionation from amphibole to more Ti-rich phases (Davidson et al., 2007; Davidson et al., 2013). Sr/Y ratios generally increase with increasing $\mathrm{Nb} / \mathrm{Ta}$ ratios, showing three distinct groups. The rhyolites, observed in the 36-28 Ma rocks, show the lowest trace-element ratios suggesting plagioclase fractionation. Andesites and basaltic andesites between 45-23 Ma have the highest $\mathrm{Nb}$ /Ta ratios with moderate $\mathrm{Sr} / \mathrm{Y}$ ratios 
suggesting rutile and plagioclase fractionation, as well as fractionation of either amphibole, garnet, or clinopyroxene, causing an upward trend. The basalts (28-24 Ma) have equivalent $\mathrm{Sr} / \mathrm{Y}$ ratios to the andesites and basaltic andesites but decrease in $\mathrm{Nb} / \mathrm{Ta}$ ratios, indicating potential fractionation of garnet or clinopyroxene.

A plot of Dy/Dy ${ }^{*}$ versus $\mathrm{Dy} / \mathrm{Yb}_{\mathrm{N}}$ is used to constrain the magmatic source and shows a general increase in Dy/Dy ${ }^{*}$ ratios with increasing $\mathrm{Dy} / \mathrm{Yb}_{\mathrm{N}}$. Comparing MDVF volcanic rocks with global island and continental arc settings, the majority of the rocks align well with a continental arc magmatic system (Fig. 7a). Older volcanic rocks of the MDVF suggest amphibole/clinopyroxene fractionation and begin enrichment in light rare-earth elements (LREE) as compositions become more basaltic. This enrichment is suggested to be the result of sediment melts (Rudnick and Fountain, 1995). The source composition shift observed from a mid-ocean ridge basalt-like (MORB) source, plotting near the bottom of the field (Fig. 7b), to an OIB-like source. This is supported by an increase in Dy and a decrease in $\mathrm{Yb}$ over time suggesting a transition from an amphibole stable source to a garnet or pyroxene stable source.

\section{Discussion}

Assessment of Arc versus Rift Geochemical Signatures. One of the most challenging questions when assessing geochemical variations and the temporal evolution of southern New Mexico igneous rocks is whether they are related to arc magmatism, rift magmatism, or a transition between the two. This question has been the focus of many past studies, some using the data presented in this study. McMillan (1998) and McMillan et al. (2000) provided the criteria of assessing sources of magmas and defined three compositional sources for southern New Mexico: subduction-modified lithospheric mantle, OIB-like mantle, and asthenospheric 
mantle. But the assessment of arc versus rift geochemical signatures is complicated for magmas in the Rio Grande rift area in southern New Mexico due to multiple episodes of arc accretion and arc magmatism since the Archean (Michelfelder and McMillian, 2012; Amato et al., 2012).

Trace-Element Insight into Temporal Variation in Crustal Thickness. Volcanic rocks in southern New Mexico record a detailed history of crustal thickening and thinning during the transition from Laramide contraction to Rio Grande rift extension. Previous estimation of paleo-crustal thickness in southern New Mexico during the Miocene and Oligocene has been problematic due to regional extension during the Basin and Range and Rio Grande Rift. Further difficultly arises from the lack of crustal shortening expressed on the surface from the Laramide orogeny. From 50-20 Ma, changes in crustal thickness provides a realistic model for the transition from intermediate magmatism from 50-36 Ma to bimodal magmatism between 36 and $28 \mathrm{Ma}$, and back to intermediate compositions after $28 \mathrm{Ma}$. Recently, the relationship between certain trace-element ratios and depth to the Moho have been suggested and quantified by a number of authors (Profeta et al., 2015; Chapman et al., 2015; Chapman et al., 2017; Ducea et al., 2015; Tang et al., 2019) and these ratios can be used to quantify magma storage (Paterson and Ducea, 2015). $\mathrm{Sr} / \mathrm{Y}$ and $(\mathrm{La} / \mathrm{Yb})_{\mathrm{N}}$ ratios show a regional and global trend in determining paleo-crustal thickness in highly active, long-lived, volcanic arcs and orogens (Profeta et al., 2015). The relationship between these two trace-element ratios and depth have been suggested for island arcs and thin crust continental arcs (Davis and Hawkesworth, 1994; Kay et al., 2010). Across-arc studies of thick crust arcs and variations at the local scale suggest that variation in these ratios may be further complicated by local basement contamination (Feeley, 1993; Feeley and Costa, 2003; Michelfelder et al., 2013). These relationships stem on the compatibility of $\mathrm{Sr}$ 
in plagioclase, $\mathrm{La}$ in amphibole and $\mathrm{Y}$ and $\mathrm{Yb}$ in garnet and the pressures at which each mineral crystallizes (Kay et al., 2010; Michelfelder and McMillan, 2013; Ducea et al., 2015).

Mafic and intermediate magmas with $\mathrm{MgO}$ concentrations of $>4.0 \mathrm{wt} \%$ and $2-4 \mathrm{wt} \%$ respectively, and $\mathrm{Rb} / \mathrm{Sr}$ ratios between 0.05 and 0.2 were used to filter samples used in paleocrustal thickness estimates to reduce the effects of mantle-slab influence and melting of metasedimentary framework rocks as suggested by Chapman et al. (2015). All crustal thicknesses were estimated using the average elevation of southern New Mexico assuming isostatic equilibrium at the horizontal scale of $50 \mathrm{~km}$ and an average crustal density of 2700 $\mathrm{kg} / \mathrm{m}^{3}$, as suggested by Profeta et al. (2015). $\mathrm{Sr} / \mathrm{Y}$ and $(\mathrm{La} / \mathrm{Yb})_{\mathrm{N}}$ ratios for basalt and intermediate composition rocks between 50-36 Ma show a general trend of crustal thickening (Fig. 8). The greatest crustal thickness calculated occurs at $36 \mathrm{Ma}$ and coincides with the change from intermediate to bimodal volcanism in southern New Mexico and the first ignimbrite forming eruptions by the Bell Top Formation (Fig. 8b; Chapin et al., 2004; Michelfelder and McMillan, 2012; Zimmerer and McIntosh, 2013; Szymanowski et al., 2017; Rentz et al., 2019). At the first appearance of mafic magmatism during bimodal magmatism at $32 \mathrm{Ma}$, both $\mathrm{Sr} / \mathrm{Y}$ and $(\mathrm{La} / \mathrm{Yb})_{\mathrm{N}}$ ratios suggest the crust underwent a dramatic thinning event. $\mathrm{Sr} / \mathrm{Y}$ and $(\mathrm{La} / \mathrm{Yb})_{\mathrm{N}}$ ratios of intermediate volcanic rocks between 28 and 20 Ma suggest a trend of crustal thinning consistent with the timing of crustal extension in the area (Mack, 2004), and coincides with the end of bimodal magmatism (McIntosh et al., 1992; Rentz et al., 2019).

While $\mathrm{Sr} / \mathrm{Y}$ and $(\mathrm{La} / \mathrm{Yb})_{\mathrm{N}}$ ratios combined with structural estimates of paleo-crustal thickness provide a compelling argument, across-strike geochemical studies of thick crust continental arcs have suggested alternative hypotheses. Alternative models suggest that high $\mathrm{Sr} / \mathrm{Y}$ and $(\mathrm{La} / \mathrm{Yb})_{\mathrm{N}}$ ratios are related to crustal composition and not depth of magma formation/ 
differentiation. Michelfelder et al. (2013) suggested a model for the Central Andes in which arcfront volcanoes with the thinnest crust display the highest $\mathrm{Sr} / \mathrm{Y}$ and $(\mathrm{La} / \mathrm{Yb})_{\mathrm{N}}$ ratios, while back arc centers constructed on thick crust, have significantly lower ratios. These authors suggested the volume of magma intruded into the arc front hybridized the crust to more mafic compositions with higher $\mathrm{Sr} / \mathrm{Y}$ ratios, imparting these ratios into the arc-front melts. Magmas in southern New Mexico intruded in much longer timescales, but have the additional problem of magma intrusion into Yavapaii-Mazatzal island arc crust (Chapin et al., 2004; Amato et al., 2008). Recently, Tang et al. (2019) suggested that $\mathrm{Nb} / \mathrm{Ta}$ ratios may be tied to crustal thickness during arc magma differentiation. These authors suggested that $\mathrm{Nb} / \mathrm{Ta}$ ratios of $\sim 19$ represent deep arc cumulates (arclogites) while continental crust and mantle basalts have lower ratios, ranging from 11-13 for continental crust and 15-16 for mantle basalts. $\mathrm{Nb} / \mathrm{Ta}$ ratios in continental arc magmas show a strong negative correlation with $\mathrm{Dy} / \mathrm{Yb}$ ratio (Fig. 9), especially at high $\mathrm{SiO}_{2}$ contents. Similar to high $\mathrm{Sr} / \mathrm{Y}$ and $\mathrm{La} / \mathrm{Yb}$ ratios, $\mathrm{Dy} / \mathrm{Yb}$ ratio is directly tied to high pressure magma differentiation/ production and the formation of garnet (Davidson et al., 2007; Alonso-Perez et al., 2009). Of particular interest, deposits of arclogites with $\mathrm{Mg} \#<0.6$ consisting of mostly garnet and oxides (Fe-Ti oxides and rutile), provide a mechanism for the fractionation of low $\mathrm{Nb} / \mathrm{Ta}$ ratio magmas in arc crusts $(\mathrm{Nb} / \mathrm{Ta}=11-13)$, with arclogite cumulates containing $\mathrm{Nb} / \mathrm{Ta}$ ratios of $>19$ (Tang et al., 2019).

Southern New Mexico volcanic rocks display a range in $\mathrm{Nb} / \mathrm{Ta}$ ratios from 11-19 and show a systematic change with age (Fig. 9). Rocks between 50 and $36 \mathrm{Ma}$ contain $\mathrm{Nb} / \mathrm{Ta}$ ratios between 12-14 and show little variation with age. It is suggested that these rocks are sourced from continental crust thinner than $55 \mathrm{~km}$ thick that are garnet stable or from subductionmodified mantle. At $36 \mathrm{Ma}$ a sharp decrease in $\mathrm{Nb} / \mathrm{Ta}$ ratio occurs with ratios dropping to $\sim 11$, 
suggesting that crustal thickening surpassed $55 \mathrm{~km}$. This is further supported by $\mathrm{Sr} / \mathrm{Y}$ and $(\mathrm{La} / \mathrm{Yb})_{\mathrm{N}}$ ratios. Maximum thickness is hypothesized to occur at $\sim 30 \mathrm{Ma}$ when $\mathrm{Nb} / \mathrm{Ta}$ ratios increase suggesting either a shift in magma source, or thinning of the crust (Fig. 9). Between 28 and $24 \mathrm{Ma}, \mathrm{Nb} / \mathrm{Ta}$ ratios significantly increase within younger volcanic rocks and peaks at $\sim 19$ within the youngest basalts and basaltic andesites of the Bearwallow Mountain Andesite (O'Dowd and Michelfelder, this volume). These ratios suggest that arclogite cumulates containing high $\mathrm{Nb} / \mathrm{Ta}$ ratios were the source of these magmas. Garnet pyroxenites have lower solidi than that of mantle peridotites, and as such, crustal thinning or mantle upwelling may easily melt and remove these deposits (Hirschmann et al., 1996; Hirschmann et al., 2003; Dasgupta et al., 2010; Tang et al., 2019). This results in up to 70\% melting under normal adiabatic mantle melting conditions, exhausting rutile early in the melting process and producing melts with similar $\mathrm{Nb} / \mathrm{Ta}$ ratios (Tang et al., 2019). The corresponding high $(\mathrm{Dy} / \mathrm{Yb})_{\mathrm{N}}$ and $(\mathrm{La} / \mathrm{Yb})_{\mathrm{N}}$ ratios of these rocks confirm the presence of a garnet-unstable source, as a direct result of crustal thinning.

Together, the trends observed in mafic and intermediate volcanic rocks between 50 and $36 \mathrm{Ma}$ are consistent with models from the Central Andes volcanic zone and Southern Rocky Mountain volcanic field which suggest that intermediate magmatism occurs during periods of crustal thickening where lower crust gabbros and equivalent metamorphic rocks are either the source or contaminant of arc magma and that these rocks migrate upward during the development of long-lived volcanic arcs. Bimodal volcanism and the ignimbrite flare-up was sourced from subduction-modified lithospheric mantle in New Mexico at $\sim 36 \mathrm{Ma}$, suggesting a change in crustal thickness as illustrated by low $\mathrm{Nb} / \mathrm{Ta},(\mathrm{La} / \mathrm{Yb})_{\mathrm{N}}, \mathrm{Sr} / \mathrm{Y}$ and $(\mathrm{Dy} / \mathrm{Yb})_{\mathrm{N}}$ ratios. Magma generation is the result of MASH development melting, large volumes of crust, and the 
fractionation of arclogite cumulates. Finally, around $28 \mathrm{Ma}$, crustal thinning and mantle upwelling return magmatism to intermediate to mafic compositions during the removal of lower crustal garnet pyroxenite cumulates containing high $\mathrm{Nb}$ /Ta ratio rutile. Near $20 \mathrm{Ma}$, complete removal and influence of the garnet pyroxenite cumulate no longer influences magma composition and asthenospheric mantle sources mafic magmatism associated with extension within in the Rio Grande rift and Basin and Range.

\section{Conclusion}

The volcanic and tectonic complexities that were involved during the mid-Tertiary ignimbrite flare-up are still controversial with respect to understanding what initiated the regional burst of magmatism and to what extent plate configuration affected magma generation. After reviewing a spectrum of previously established tecto-magmatic models, it is difficult to provide a clear understanding of the magma storage systems and how the style and composition of volcanism changed with time. However, the majority of these proposed models suggest flat slab subduction of the Farallon plate followed by delamination or tearing, triggered widespread volcanism far inland within the North American plate (Best et al., 2016). The initiation of the ignimbrite flare-up was also suggested to be contemporaneous with the onset of ductile extension as compressional stresses began to relax, creating a relatively passive tectonic regime before further crustal extension (Elston, 2008). The majority of volcanism ( 36-23 Ma) was likely sourced from partial melting of the lithospheric mantle and incorporating arc signatures from previous subduction events (McMillan, 1998; Farmer et al., 2007). It is not until after the ignimbrite flare-up in which the magmatic source picks up more enriched mantle compositions, suggesting partial melting of the asthenosphere (Davis and Hawkesworth, 1996). This transition 
to Rio Grande rift magmatism corresponds to a change in thermal regimes as brittle extension becomes more predominate.

Combining current databases of compiled geochemical analyses from literature with newly collected data from regionally extensive units/phases in southern New Mexico, the arc-rift transition during the ignimbrite flare-up can be evaluated with respect to variations in crustal thickness. Using REE patterns and trace-element ratios of $(\mathrm{La} / \mathrm{Yb})_{\mathrm{N}},(\mathrm{Dy} / \mathrm{Yb})_{\mathrm{N}}, \mathrm{Nb} / \mathrm{Ta}$, and $\mathrm{Sr} / \mathrm{Y}$, it is evident that a dramatic change in crustal thickness accompanies the initiation of the ignimbrite flare-up and the change in the style of volcanism. Inserting these trace-element trends into the context of previously established regional models, early erupted intermediate composition volcanic rocks (50-36 Ma) show trace-element signatures sourced from crust thinner than $55 \mathrm{~km}$ thick. During the initiation of the ignimbrite flare-up, marked at $36 \mathrm{Ma}$, traceelement compositions suggest crustal thickening with maximum thickness hypothesized to have occurred near 30 Ma before a significant crustal thinning event or a change in magma source. The increase in $\mathrm{Nb} / \mathrm{Ta}$ ratios to unusually high values near $\sim 19$ within the youngest basalts and basaltic andesites of the Bearwallow Mountain Andesite may suggest the incorporation of rutilebearing pyroxenite cumulates (arclogite; Tang et al., 2019) after peak extension of the lithosphere and continental crust. $\mathrm{Nb} / \mathrm{Ta}$ ratios transition to enriched mantle values towards the end of the ignimbrite flare-up as volcanism becomes more effusive during Rio Grande rift magmatism. This change in crustal thickness may provide a model for the transition in magmatism from intermediate compositions (50-36 Ma) to bimodal compositions (36-28 Ma), followed by a progressive change to basaltic magmatism (28-0 Ma). 


\section{References Cited}

Alonso-Perez, R., Muntener, O., and Ulmer, P., 2009, Igneous garnet and amphibole fractionation in the roots of island arcs: experimental constraints on andesitic liquids: Contributions to Mineralogy and Petrology, v. 157, no. 4, p. 541-558.

Amato, J., Athens, C., McIntosh, W.C., and Peters, L., 2012, U-Pb zircon ages from crustal xenoliths in a Pliocene basalt flow from the southern Rio Grande Rift: Implications for the timing of extension and magmatism: New Mexico Geological Society Guidebook, v. 63 , p. 273-284.

Amato, J. M., Boullion, A. O., Serna, A.M., Sanders, A. E., Farmer, G. L., Gehrels, G. E., and Wooden, J. L., 2008, Evolution of the Mazatzal province and the timing of the Mazatzal orogeny: Insights from $\mathrm{U}-\mathrm{Pb}$ geochronology and geochemistry of igneous and metasedimentary rocks in southern New Mexico: Geological Society of America Bulletin, v. 120, no. 3-4, p. 328-346.

Anderson, R.E., Beard, L.S., Mankinen, E.A., and Hillhouse, J.W., 2013, Analysis of Neogene deformation between Beaver, Utah, and Barstow, California: Suggestions for altering the extensional paradigm, in Anderson, R.E., ed., Neogene Deformation between Central Utah and the Mojave Desert: Geological Society of America Special Paper 499, p. 1-67, doi:10.1130/2013.2499(01).

Annen, C., Blundy, J.D., and Sparks, R.S.J., 2006, The genesis of intermediate and silicic magmas in deep crustal hot zones: Journal of Petrology, v. 47, no. 3, p. 505-539, doi: 10.1093/petrology/egi084.

Armstrong, P.A., Ehlers, T.A., Chapman, D.S., Farley, K.A., and Kamp, P.J.J., 2003, Exhumation of the central Wasatch Mountains, Utah: 1. Patterns and timing of exhumation deduced from low-temperature thermochronology data: Journal of Geophysical Research, v. 108, p. 17, doi: 10.1029/2001JB001708.

Atwater, T., 1970, Implication for plate tectonics of the Cenozoic tectonic evolution of western North America: Geological Society of America Bulletin, v.81, 3518-3586.

Atwater, T., 1989, Plate tectonic history of the northeast Pacific and western North America, in Winterer, E.L., Hussong, D.L., and Decker, R.W., eds., The Eastern Pacific Ocean and Hawaii: Geological Society of America, The Geology of North America, v. N, p.21-72.

Baldridge, W.S., Keller, G.R., llaak, V., Wendlandt, E., Jiracek, G.R., and Olsen, K.H., 1995, The Rio Grande rift; in Olsen, K. H., ed., Continental rifts: evolution, structure, tectonics: Developments in Geotectonics 25, Elsevier Science B.V., Amsterdam, The Netherlands, p. 233-265.

Best, M.G., and Christiansen, E.H., 1991, Limited extension during peak Tertiary volcanism, Great Basin of Nevada and Utah: Journal of Geophysical Research: Solid Earth, v. 96, no. B8, p. 13509-13528. 
Best, M.G., Christiansen, E.H., de Silva, S., and Lipman, P.W., 2016, Slab-rollback ignimbrite flareups in the southern Great Basin and other Cenozoic American arcs: A distinct style of arc volcanism: Geosphere, v. 12, no. 4, p. 1097-1135, doi:10 .1130/GES01285.1.

Bikerman, M., Bell, K., and Card, J.W., 1990, Strontium and neodymium isotopic study of the western Mogollon-Datil volcanic region, New Mexico, USA: Contributions to Mineralogy and Petrology, v. 109, no. 4, p. 459-470, doi:10.1007/bf00306549.

Bornhorst, T.J., 1980, Major-and trace-element geochemistry and mineralogy of upper Eocene to Quaternary volcanic rocks, Mogollon-Datil volcanic field, southwestern New Mexico [Ph.D. dissertation]: Albuquerque, University of New Mexico, p. 346.

Bornhorst, T.J., 1988, Character of mid-Cenozoic andesites, basaltic andesites, and related volcanic rocks, Mogollon-Datil volcanic field, New Mexico: Colorado School of Mines Quarterly, v. 83, p. 1-11.

Cameron, K.L., Nimz, G.J., Kuentz, D., Niemeyer, S., and Gunn, S., 1989, Southern Cordilleran basaltic andesite suite, southern Chihuahua, Mexico: A link between Tertiary continental arc and flood basalt magmatism in North America: Journal of Geophysical Research, v. 94, p. 7817-7840, doi:10.1029/JB094iB06p07817.

Carlson, R.L., Hilde, T.W.C., and Uyeda, S., 1983, The driving mechanism of plate tectonics: relation to age of the lithosphere at trenches: Geophysical Research Letters, v. 10, p. $297-$ 300.

Cather, S.M., 1990, Stress and volcanism in the northern Mogollon-Datil volcanic field, New Mexico: Effects of the post-Laramide tectonic transition: Geological Society of America Bulletin, v. 102, p. 1447-1458.

Chamberlin, R.M., Eggleston, T.L., and McIntosh, W.C., 2002, Geology of the Luis Lopez 7.5 minute quadrangle, Socorro County, New Mexico: New Mexico Bureau of Geology and Mineral Resources, Openfile Digital Map Series OFDM53, p. 46, scale 1:24,000.

Chamberlin, R.M., McIntosh, W.C., Eggleston, T.L., 2004, ${ }^{40} \mathrm{Ar} /{ }^{39} \mathrm{Ar}$ geochronology and eruptive history of the eastern sector of the Oligocene Socorro caldera, central Rio Grande rift, New Mexico: New Mexico Bureau of Geology and Mineral Resources, Bulletin 160, p. 251-280.

Chapin, C.E., Seager, R.W., 1975, Evolution of the Rio Grande Rift in the Socorro and Las Cruces areas: New Mexico Geol. Soc. Guidebook, $26^{\text {th }}$ Field Conference, p. 297-321.

Chapin, C.E., Wilks, M., and McIntosh, W.C., 2004, Spacetime patterns of late Cretaceous to present magmatism in New Mexico - comparison with Andean volcanism and potential for future volcanism: New Mexico Bureau of Geology and Mineral Resources, Bulletin, v. 160 , p. $13-40$. 
Chapman, J. B., Ducea, M.N., DeCelles, P.G., and Profeta, L., 2015, Tracking changes in crustal thickness during orogenic evolution with $\mathrm{Sr} / \mathrm{Y}$ : An example from the North American Cordillera: Geology, v. 43, no. 10, p. 919-922.

Chapman, J. B., Ducea, M.N., Kapp, P., Gehrels, G.E., and DeCelles, P.G., 2017, Spatial and temporal radiogenic isotopic trends of magmatism in Cordilleran orogens: Gondwana Research, v. 48, p. 189-204.

Christiansen, E.H., and Best, M.G., 2014, Constraints on the origin of subduction-related ignimbrite flareups from source volume calculations: The southern Great Basin ignimbrite province: Geological Society of America Abstracts with Programs, v. 46, no. 6, p. 374.

Colgan, J.P., and Henry, C.D., 2009, Rapid middle Miocene collapse of the Mesozoic orogenic plateau in north-central Nevada: International Geology Review, v. 51, p. 920-961, doi:10.1080/00206810903056731.

Coney, P.J., 1972, Cordilleran tectonics and North American plate motion: American Journal of Science, v. 272, p. 603-628.

Coney, P.J., 1978, Mesozoic-Cenozoic Cordilleran plate tectonics, in Smith, R.B., and Eaton, G.P., eds., Cenozoic tectonics and regional geophysics of the western Cordillera: Geological Society of America Memoir 152, p. 33-50, doi: 10 .1130/MEM152 -p33.

Cooper, K.M., and Kent, A.J., 2014, Rapid remobilization of magmatic crystals kept in cold storage: Nature, v. 506, p. 480-483, doi:10.1038/nature12991.

Dasgupta, R., Jackson, M.G., and Lee, C.T.A., 2010, Major element chemistry of ocean island basalts - conditions of mantle melting and heterogeneity of mantle source: Earth and Planetary Science Letters, v. 289, no. 3-4, p. 377-392.

Davidson, J., Turner, S., Handley, H., Macpherson, C., and Dosseto, A., 2007, Amphibole "sponge" in arc crust?: Geology, v. 35, no. 9, p. 787-790.

Davidson, J., Turner, S., and Plank, T., 2013, Dy/Dy*: variations arising from mantle sources and petrogenetic processes: Journal of Petrology, v. 54, no. 3, p. 525-537.

Davis, J. M., Elston, W. E., and Hawkesworth, C.J., 1993, Basic and intermediate volcanism of the Mogollon-Datil volcanic field: implications for mid-Tertiary tectonic transitions in southwestern New Mexico, USA: Geological Society, London, Special Publications, v. 76, no. 1, 469-488, doi:10.1144/gsl.sp.1993.076.01.25.

Davis, J.M., and Hawkesworth, C.J., 1993, The petrogenesis of 30-20 Ma basic and intermediate volcanics from the Mogollon-Datil volcanic field, New Mexico, USA: Contributions to Mineralogy and Petrology, v. 115, no. 2, p. 165-183, doi: 10.1007/BF00321218. 
Davis, J.M., and Hawkesworth, C.J., 1994, Early calc-alkaline magmatism in the Mogollon-Datil volcanic field, New Mexico, USA: Journal of the Geological Society, London, v. 151, no. 5, p. 825-843, doi: 10.1144/gsjgs.151.5.0825.

Davis, J.M., and Hawkesworth, C.J., 1995, Geochemical and tectonic transitions in the evolution of the Mogollon-Datil volcanic field, New Mexico, U.S.A.: Chemical Geology, v. 119, p. $31-53$.

DePaolo, D.J., 1981, Trace element and isotopic effects of combined wallrock assimilation and fractional crystallization: Earth Planet Science Letters, v. 53, p. 189-202.

Ducea, M.N., and Barton, M.D., 2007, Igniting flare-up events in Cordilleran arcs: Geology, v. 35, no. 11, p. 1047, doi:10.1130/g23898a.1.

Ducea, M.N., Saleeby, J.B., and Bergantz, G., 2015, The architecture, chemistry, and evolution of continental magmatic arcs: Annual Review of Earth and Planetary Sciences, v. 43, p. $299-331$.

Eichelberger, J. C., 1978, Andesitic volcanism and crustal evolution: Nature, v. 275, pp. 21-27.

Eichelberger, J. C., 1980, Vesiculation of mafic magma during replenishment of silicic magma reservoirs: Nature, v. 288, pp. 446-450.

Elston, W.E., 1989, Overview of the Mogollon-Datil volcanic field, in Chapin, C.E., Zidek, J., eds., Field excursions to volcanic terranes in the western United States, Southern Rocky Mountain region: New Mexico Bureau of Geology and Mineral Resources, v. 1, no. 46, p. 43-46.

Elston, W.E., 2008, When batholiths exploded: The Mogollon-Datil volcanic field, southwestern New Mexico, in Mack, G., Witcher, J., and Lueth, V.W., eds., Geology of the Gila area wilderness- Silver City area: New Mexico Geological Society Guidebook, 59th Field Conference, p. 117-128.

Elston, W.E., Damon, P.E., Coney, P.J., Rhodes, R.C., and Bikerman, M., 1973, Tertiary volcanic rocks, Mogollon-Datil province, New Mexico, and surrounding regions: Geological Society of America Bulletin, v. 84, p. 2259-2274.

Elston, W.E., Damon, P.E., Coney, P.J., Deal, E.G., 1976, Progress report on the Mogollon Plateau volcanic field, southwestern New Mexico, No. 3 - surface expression of a pluton, in Elston, W.E., Northrop, S.A., eds., Cenozoic volcanism in southwestern New Mexico: New Mexico Geological Society, Special Publication, v. 5, p. 3-26.

English, J.M., Johnston, S.T., and Wang, K., 2003, Thermal modelling of the Laramide orogeny: testing the flat-slab subduction hypothesis: Earth and Planetary Science Letters, v. 214, no. 3-4, p. 619-632. 
Farmer, L.G., Bailley, T., Elkins-Tanton, L.T., 2007, Mantle source volumes and the origin of the mid-tertiary ignimbrite flare-up in the southern Rocky Mountains, western U.S.: Lithos, v. 102, p. 279-294.

Feeley, T.C., 1993, Crustal modification during subduction-zone magmatism: Evidence from the southern Salar De Uyuni region $\left(20^{\circ}-22^{\circ} \mathrm{S}\right)$, central Andes: Geology, v. 21, no. 11, p. 1019-1022.

Feeley, T.C., and Cosca, M. A., 2003, Time vs. composition trends of magmatism at Sunlight volcano, Absaroka volcanic province, Wyoming: Geological Society of America Bulletin, v. 115, no. 6, p. 714-728.

Fodor, R.V., 1975, Petrology of basalt and andesite of the Black Range, New Mexico: Geological Society of America Bulletin, v. 85, p. 295-304.

Gibson, S.A., Thompson, R.N., Leat, P.T., Dickin, A.P., Morrison, M.A., Hendry, G.L., and Mitchell, J.G., 1992, Asthenosphere-derived magmatism in the Rio Grande rift, western USA: implications for continental break-up, in Story, B.C., Alabaster, T., and Pankhurst, R.J. (eds) Magmatism and the Causes of Continental Break-up: Geological Society, London, Special Publications, v. 68, p. 61-89.

Gutscher, M.A., Maury, R., Eissen, J.P., and Bourdon, E., 2000, Can slab melting be caused by flat subduction?: Geology, v. 28, no. 6, p. 535-538.

Henry, C.D., and Price, J.G., 1986, Early Basin and Range development in Trans-Pecos Texas and adjacent Chihuahua: magmatism and orientation, timing, and style of extension: Journal of Geophysical Research, v. 91, no. B6, p. 6213-6224.

Henry, C.D., McGrew, A.J., Colgan, J.P., Snoke, A.W., and Brueseke, M.E., 2011, Timing, distribution, amount, and style of Cenozoic extension in the northern Great Basin, in Lee, J., and Evans, J.P., eds., Geologic Field Trips to the Basin and Range, Rocky Mountains, Snake River Plain, and Terranes of the U.S. Cordillera: Geological Society of America Field Guide 21, p. 27-66.

Hildreth, W. and Moorbath, S., 1988, Crustal contribution to arc magmatism in the Andes of Central Chile: Contributions to Mineralogy and Petrology, v. 98, 455-489.

Hirschmann, M.M., and Stolper, E.M., 1996, A possible role for garnet pyroxenite in the origin of the "garnet signature" in MORB: Contributions to Mineralogy and Petrology, v. 124, no. 2, p. 185-208.

Hirschmann, M.M., Kogiso, T., Baker, M.B., and Stolper, E.M., 2003, Alkalic magmas generated by partial melting of garnet pyroxenite: Geology, v. 31, no. 6, p. 481-484.

Humphreys, E.D., 1995, Post-Laramide removal of the Farallon Slab, western United States: Geology 11, p. 987-990. 
Humphreys, E.D., 2009, Relation of flat subduction to magmatism and deformation in the western United States, in Kay, S.M., Ramos, V.A., and Dickinson, W.R., eds., Backbone of Americas: Shallow subduction, plateau uplift, and terrance collision: Geological Society of America Memoir, v. 204, p. 85-98, doi:101130/2009.1204(04).

Jarvis, K.E., 1988, Inductively coupled plasma mass spectrometry; a new technique for the rapid or ultra-trace level determination of the rare-earth elements in geological materials: Chemical Geology, v. 68, p. 31-39.

Johnson, D.M., Hooper, P.R., and Conrey, R.M., 1999, XRF analysis of rock and minerals for major and trace elements on a single low dilution Li-tetraborate fused bead: Advances in X-ray analysis, v. 41, p. 843-867.

Kay, S.M., Coira, B.L., Caffe, P.J., and Chen, C.H., 2010, Regional chemical diversity, crustal and mantle sources and evolution of central Andean Puna plateau ignimbrites: Journal of Volcanology and Geothermal Research, v. 198, no. 1-2, p. 81-111.

Kent, A.J., 2016, Preferential eruption of andesitic magmas: Implications for volcanic magma fluxes at convergent margins: Geological Society, London, Special Publications, v. 385, no. 1 , p. 257-280, doi:10.1144/sp385.10.

Le Bas, M., Le Maitre, R., Streckeisen, A., Zanettin, B., 1986, A chemical classification of volcanic rocks based on the total alkali-silica diagram: Journal of Petrology v. 27, p. 745750 .

Leeman, W.P., Harry, D.L., 1993, A binary source model for extension-related magmatism in the Great Basin, western North America: Science, v. 262, p. 1550-1554.

Lipman, P.W., 1980, Cenozoic volcanism in the western United States-Implications for continental tectonics, in Burchfiel, B.C., Oliver, J.E., and Silver, L.T., eds., Continental Tectonics: Washington, D.C., National Research Council, p. 161-174.

Lipman, P.W., 2007, Incremental assembly and prolonged consolidation of Cordilleran magma chambers: Evidence from the Southern Rocky Mountain volcanic field: Geosphere, v. 3, p. 42-70, doi: $10.1130 / \mathrm{GES} 00061.1$.

Lipman, P.W., Prostka, H.J., and Christiansen, R.L., 1972, Cenozoic volcanism and plate tectonic evolution of western United States: Part 1. Early and middle Cenozoic: Philosophical Transactions of the Royal Society of London, v. 271, p. 217-248, doi:10.1098/rsta.1972.0008.

MacDonald, G.A., and Katsura T., 1964, Chemical composition of Hawaiian lavas: Journal of Petrology, v. 5, p. 82-133.

Mack, G.H., 2004, Middle and late Cenozoic crustal extension, sedimentation, and volcanism in the southern Rio Grande rift, Basin and Range, and southern Transition Zone of southwestern New Mexico, in Mack G.H and Giles, K.A., eds., The Geology of New 
Mexico: A Geologic History: New Mexico Geological Society, Special Publication 11, p. 389-406.

Marvin, R.F., Naeser, C.W., Bikerman, M., Mehnert, H.H., Ratté, J.C., 1987, Isotopic ages of post-Paleocene igneous rocks within and bordering the Clifton $1^{\circ} \times 2^{\circ}$ quadrangle, Arizona-New Mexico: New Mexico Bureau of Geology and Mineral Resources, p. 118.

McDonough, W. F. and Sun, S-s. The composition of the Earth: Chemical Geology, v. 120, p. 223-253, 1995.

McIntosh, W.C., Chapin, C.E., Ratté, J.C., and Sutter, J.F., 1992, Time-stratigraphic framework for the Eocene-Oligocene Mogollon-Datil volcanic field, southwest New Mexico: Geological Society of America Bulletin, v. 104, no. 7, p. 851-871.

McKenzie, D., 1989, Some remarks on the movement of small melt fractions in the mantle: Earth and Planetary Science Letters, v. 95, p. 53-72.

McKenzie, D., and Bickle, M.J., 1988, The volume and composition of melt generated by extension of the lithosphere: Journal of Petrology, v. 29, p. 625-679.

McMillan, N.J., 1998, Temporal and spatial magmatic evolution of the Rio Grande rift, in Mack, G.H., Austin, G.S., and Barker, J.M., eds., Las Cruces Country II: New Mexico Geological Society 49th Annual Fall Field Conference Guidebook, p. 107-116.

McMillan, N.J., Dickin, A.P., and Haag, D., 2000, Evolution of magma source regions in the Rio Grande rift, southern New Mexico: Geological Society of America Bulletin, v. 112, p. 1582-1593.

McQuarrie, N., and Oskin, M., 2010, Palinspastic restoration of NavDAT and implications for the origin of magmatism in southwestern North America: Journal of Geophysical Research, v. 115, no. B10, doi: 10.1029 /2009JB006435.

McQuarrie, N., and Wernicke, B.P., 2005, An animated tectonic reconstruction of southwestern North America since 36 Ma: Geosphere, v. 1, p. 147-172, doi:10.1130/GES00016.1.

Menard, H.W., 1978, Fragmentation of the Farallon plate by pivoting subduction: The Journal of Geology, v. 86, no. 1, p. 99-110, doi:10.1086/649658.

Michelfelder, G.S. and McMillan, N.J., 2012, Geochemistry, origin, and U-Pb zircon ages of the Sierra Cuchillo Laccolith, Sierra County, New Mexico, in Lucas, S.G., McLemore, V.T., Lueth, V.W., Spielmann, J.A., and Krainer, K., eds., Geology of 122 the Warm Springs Region: New Mexico Geological Society, 63rd Annual Field Conference, Guidebook, p. 249-260.

Michelfelder, G., Feeley, T., Wilder, A., and Klemetti, E., 2013, Modification of the continental crust by subduction zone magmatism and vice-versa: Across-Strike geochemical variations of silicic lavas from individual eruptive centers in the Andean central volcanic zone: Geosciences, v. 3, no. 4, p. 633-667. 
Mutschler, F.E., Larson, E.E., Bruce, R.M., 1987, Laramide and younger magmatism in Colorado - new petrologic and tectonic variations on old themes: Colorado School of Mines Quarterly, v. 82, no. 4, p. 1-47.

Paterson, S.R., and Ducea, M.N., 2015, Arc magmatic tempos: gathering the evidence: Elements, v. 11 , no. 2, p. 91-98.

Perry, F.V., Baldridge, W.S., and DePaolo, D.J., 1987, Role of asthenosphere and lithosphere in the genesis of late Cenozoic basaltic rocks from the Rio Grande Rift and adjacent regions of the southwestern United States: Journal of Geophysical Research, v. 92, p. 9193-9213, doi: 10.1029/ JB092iB09p09193.

Perry, F.V., Baldridge, W.S., and DePaolo, D.J., 1988, Chemical and isotopic evidence for lithospheric thinning beneath the Rio Grande Rift: Nature, v. 332, p. 432-434, doi: $10.1038 / 332432 \mathrm{a} 0$.

Profeta, L., Ducea, M.N., Chapman, J.B., Paterson, S.R., Gonzales, S.M.H., Kirsch, M., Petrescu, L., and DeCelles, P. G., 2015, Quantifying crustal thickness over time in magmatic arcs: Scientific Reports, v. 5, p. 17786.

Ratté, J.C., Marvin, R.F., and Naeser, C.W., 1984, Calderas and ash flow tuffs of the Mogollon Mountains, southwestern New Mexico: Journal of Geophysical Research, v. 89, no. B10, p. 8713-8732, doi: 10.1029/JB089iB10p08713.

Rentz, S.P., Michelfelder, G.S., Coble, M.A., and Salings, E., 2019, U-Pb zircon geochronology of calc-alkaline ash-flow tuff units in the Mogollon-Datil volcanic field, southern New Mexico.

Rudnick, R.L., and Fountain, D.M., 1995, Nature and composition of the continental crust: a lower crustal perspective: Reviews in Geophysics, v. 33, p. 267-309.

Severinghaus, J., and Awater, T., 1990, Cenozoic geometry and thermal state of the subducting slabs beneath western North America, in Wernicke, B.P., ed., Basin and Range extensional tectonics near the latitude of Las Vegas, Nevada: Geological Society of America Memoir, v. 176, p. 1-22, doi:10.1130?MEM176-p1.

Sigloch, K., McQuarrie, N., and Nolet, G., 2008, Two-stage subduction history under North America inferred from multiple-frequency tomography: Nature Geoscience, v. 1, p. 458462, doi: 10.1038/ngeo231.

Smith, D.L., Gans, P.B., and Miller, E.A., 1991, Palinspastic restoration of Cenozoic extension in the central and eastern Basin and Range Province at latitude $39-40^{\circ} \mathrm{N}$, in Raines, G.L., Lisle, R.E., Schafer, R.W., and Wilkinson, W.J., eds., Geology and Ore Deposits of the Great Basin: Symposium Proceedings, sponsored by the Geological Society of Nevada and the U.S. Geological Survey, April 1-5, 1990: Reno, Nevada, Geological Society of Nevada, p. 75-86. 
Straub, S.M., Gómez-Tuena, A., Bindeman, I.N., Bolge, L.L., Brandl, P.A., Espinasa-Pereña, R., . . . Zellmer, G. F., 2015, Corrigendum to "Crustal recycling by subduction erosion in the central Mexican Volcanic Belt" [Geochim. Cosmochim. Acta 166, 2015, p. 29-52]:

Geochimica Et Cosmochimica Acta, v. 171, p. 374-375, doi:10.1016/j.gca.2015.09.028.

Szymanowski, D., Wotzlaw, J.F., Ellis, B.S., Bachmann, O., Guillong, M., and von Quadt, A., 2017, Protracted near-solidus storage and pre-eruptive rejuvenation of large magma reservoirs: Nature Geoscience, v. 10, no. 10, p. 777.

Tang, M., Lee, C.A., Chen, K., Erdman, M., Costin, G., and Jiang, H., 2019, Nb/Ta systematics in arc magma differentiation and the role of arclogites in continent formation: Nature Communications, v. 10, no. 1, doi:10.1038/s41467-018-08198-3.

Usui, T., Nakamura, E., Kobayashi, K., Maruyama, S., and Helmstaedt, H., 2003, Fate of the subducted Farallon plate inferred from eclogitic xenoliths in the Colorado Plateau: Geology, v. 31, p. 589-592, doi:10.1130/0091-7613(2003)031.

Wernicke, B.P., Christiansen, R.L., England, P.C., and Sonder, L.J., 1987, Tectonomagmatic evolution of Cenozoic extension in the North American Cordillera, in Coward, M.P., Dewey, J.F. and Hancock, P.L. eds., Continental extensional tectonics: Geological Society, London, Special Publications, v. 28, p. 203-221.

Zimmerer, M.J., and McIntosh, W.C., 2013, Geochronologic evidence of upper-crustal in situ differentiation: Silicic magmatism at the Organ caldera complex, New Mexico:

Geosphere, v. 9, no. 1, p. 155-169. 


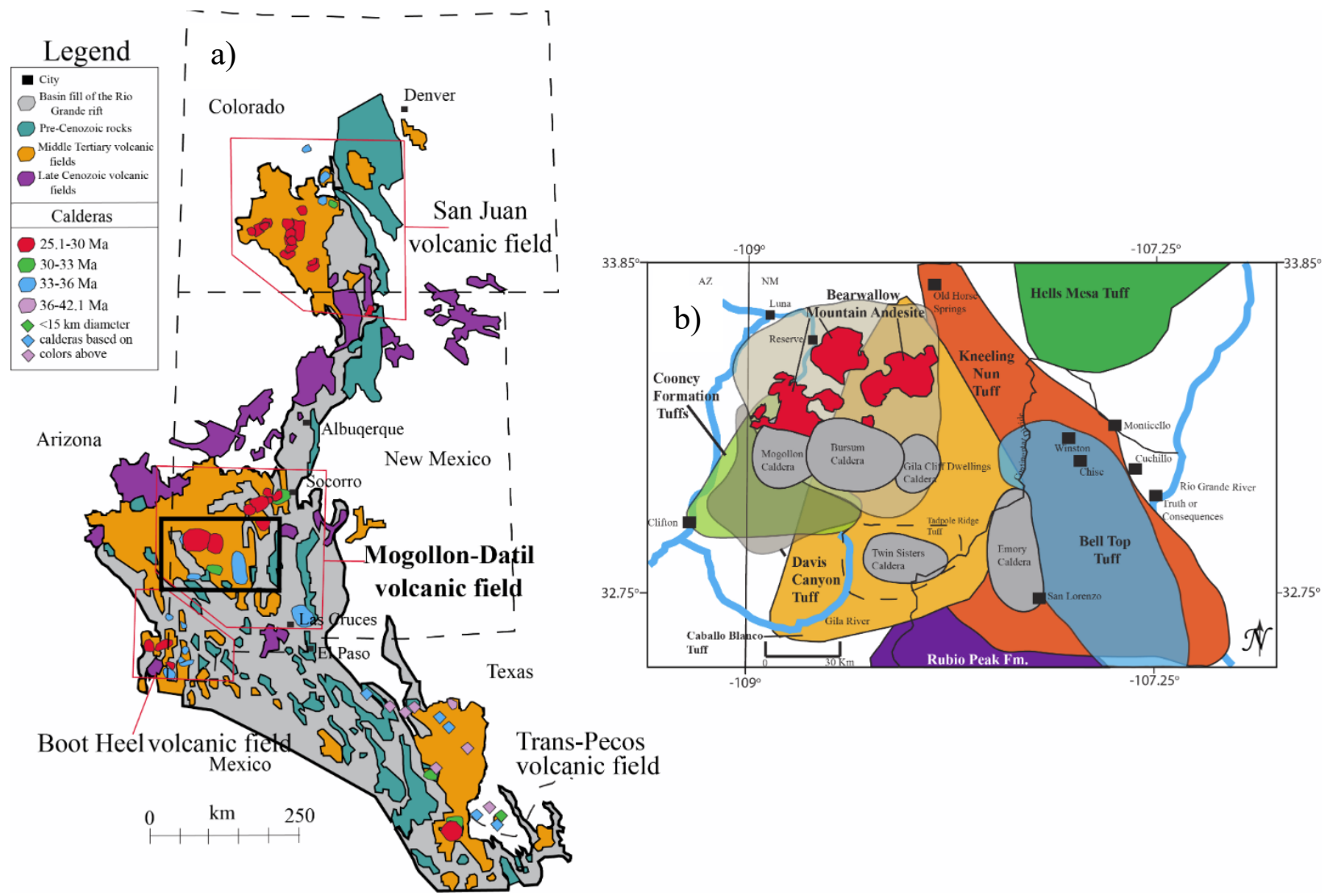

Figure 1. a) Regional map of the Mogollon-Datil volcanic field (MDVF) and Rio Grande rift volcanic area and b) north-central extent of the MDVF outlining caldera locations, major ignimbrite ash-flow tuffs, and the Bearwallow Mountain Andesite lava flows. 


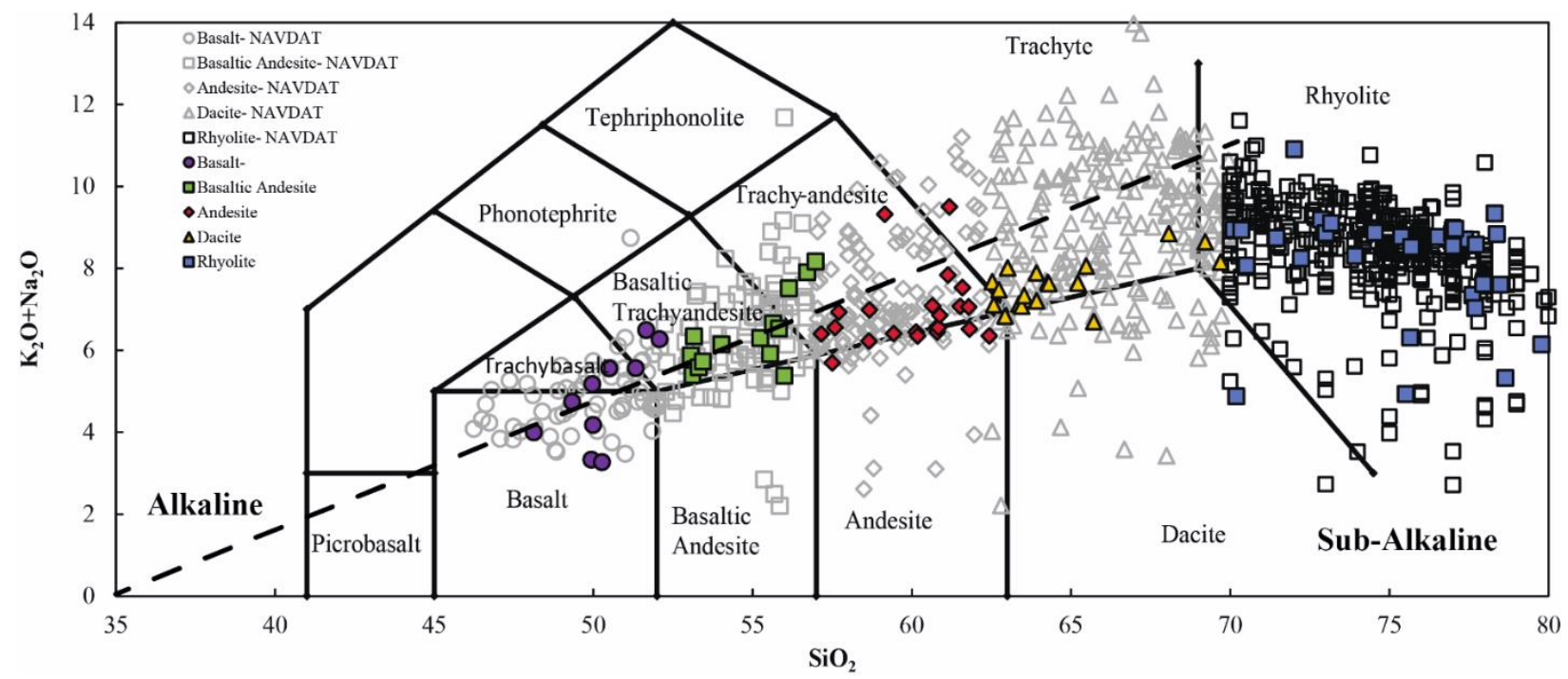

Figure 2. Total alkali vs. silica diagram for volcanic rocks in the MDVF (filled symbols) and from the NAVDAT database (unfilled symbols), using the IUGS classification defined by Le Bas et al. (1986). Basalts are shown in purple, basaltic andesites are shown in green, andesites are shown in red, dacites are shown in yellow, and rhyolites are shown in blue. Also shown is the alkali/subalkalic division of MacDonald and Katsura (1964). 

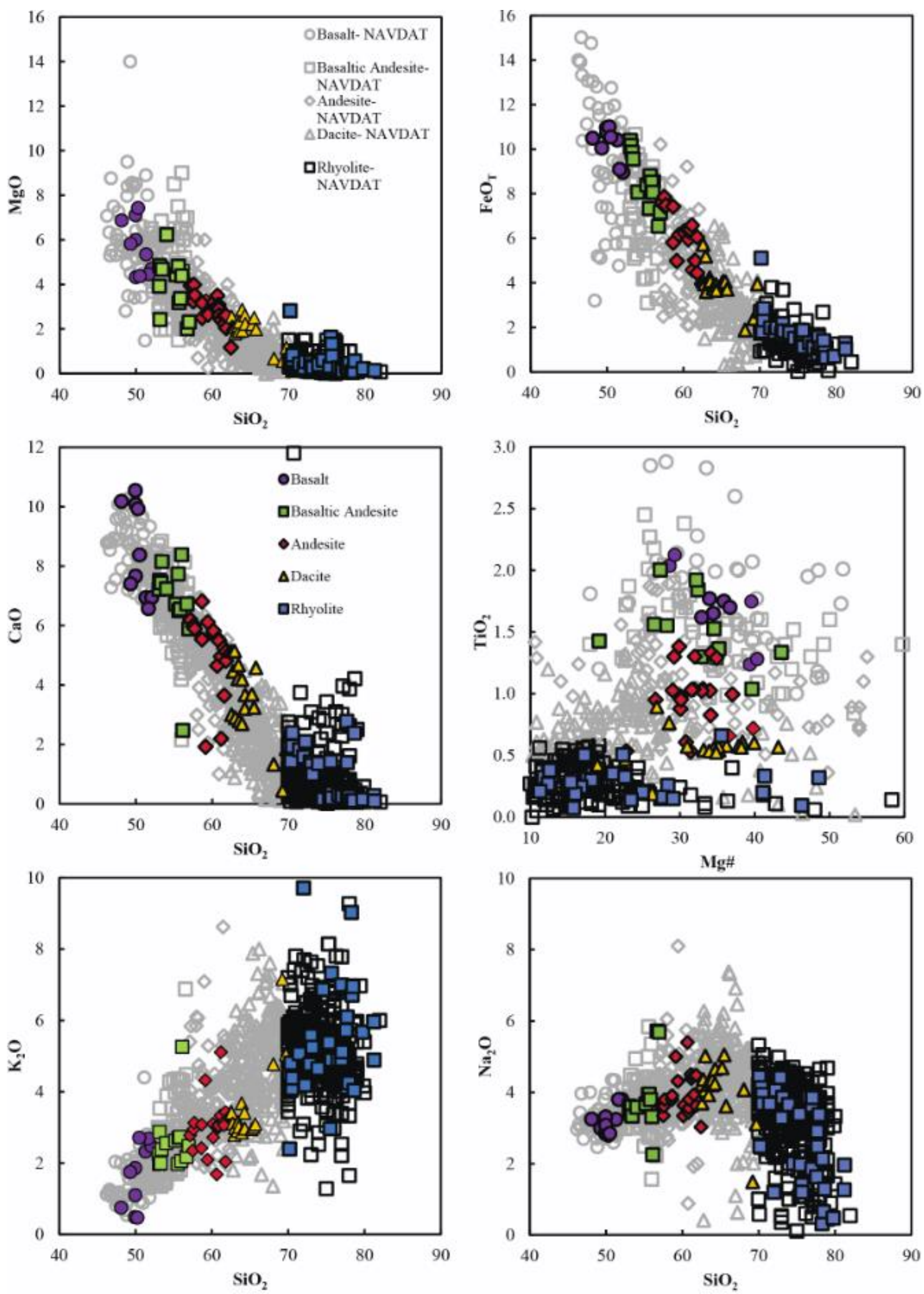

Figure 3. Selected major-element Harker diagrams for volcanic rocks in the MDVF (filled symbols) and from the NAVDAT database (unfilled symbols). 

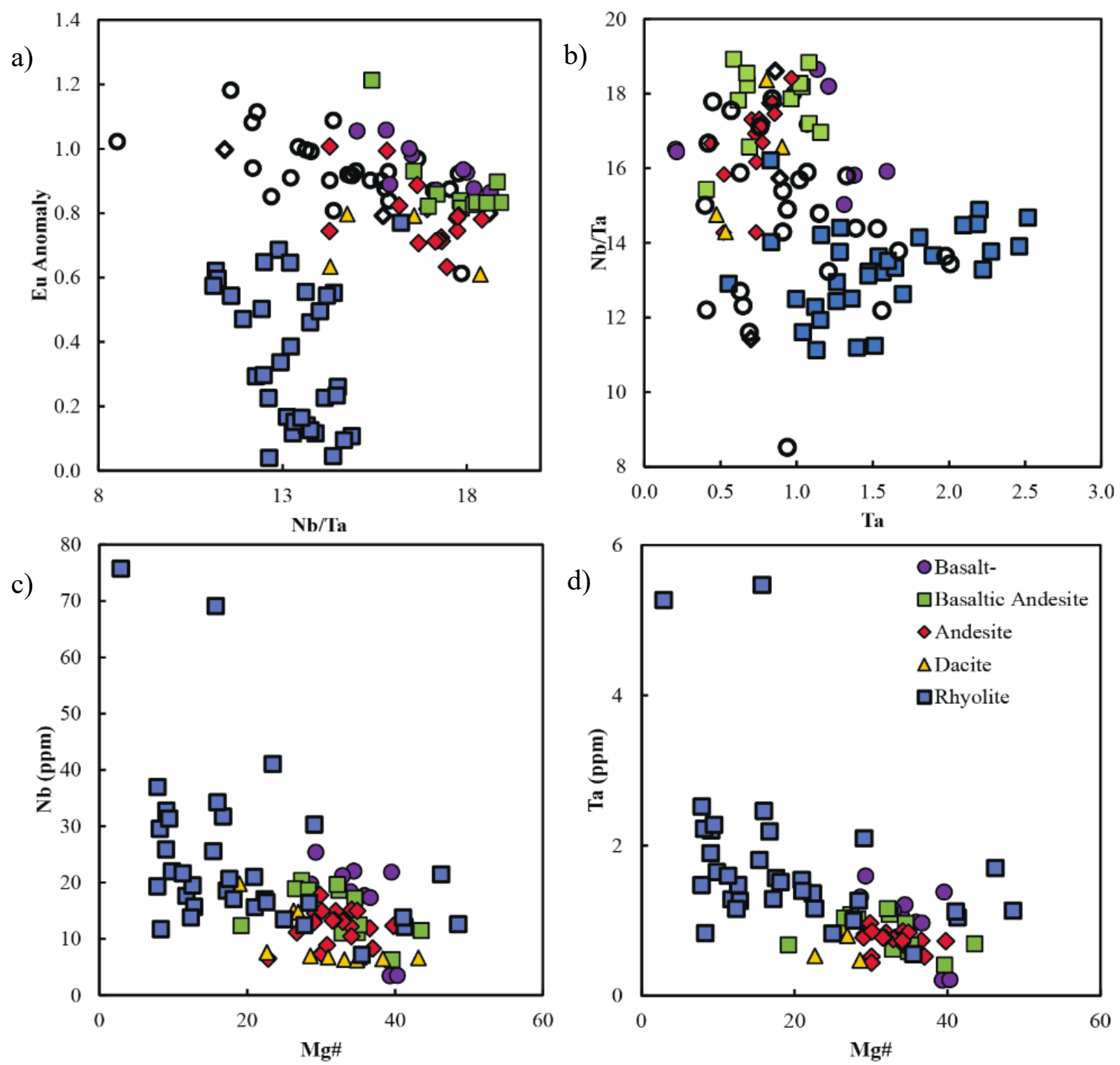

Figure 4. Bivariate trace-element plots: a) $\mathrm{Eu} / \mathrm{Eu} *$ versus $\mathrm{Nb} / \mathrm{Ta}$; b) $\mathrm{Nb} / \mathrm{Ta}$ versus $\mathrm{Ta}$; c) $\mathrm{Nb}$ versus $\mathrm{Mg \# ;}$ d) Ta versus $\mathrm{Mg \# \text {. }}$ 

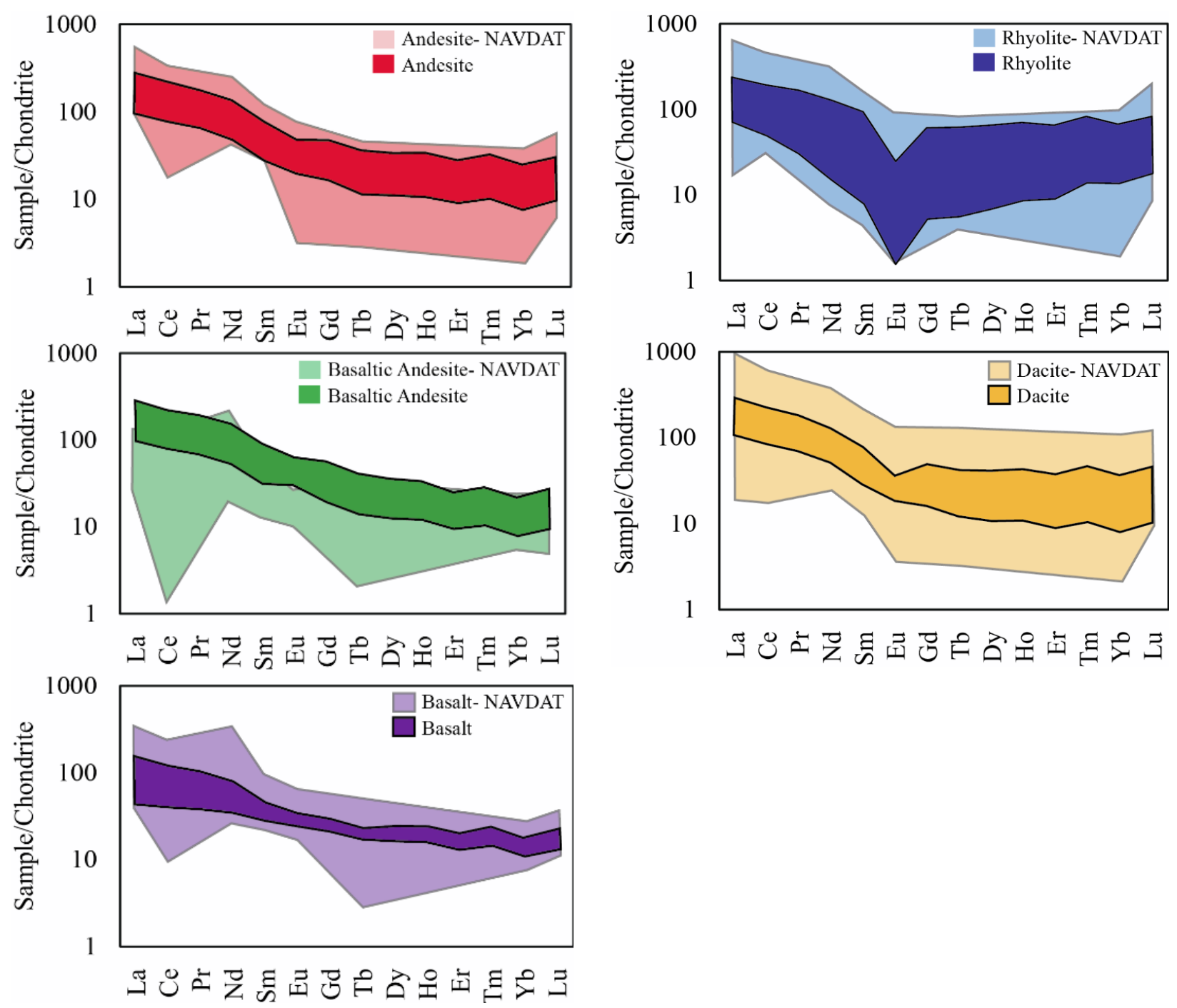

Figure 5. Chondrite-normalized rare-earth element patterns of volcanic rocks in the MDVF, ranging from basalt to rhyolite in composition. 

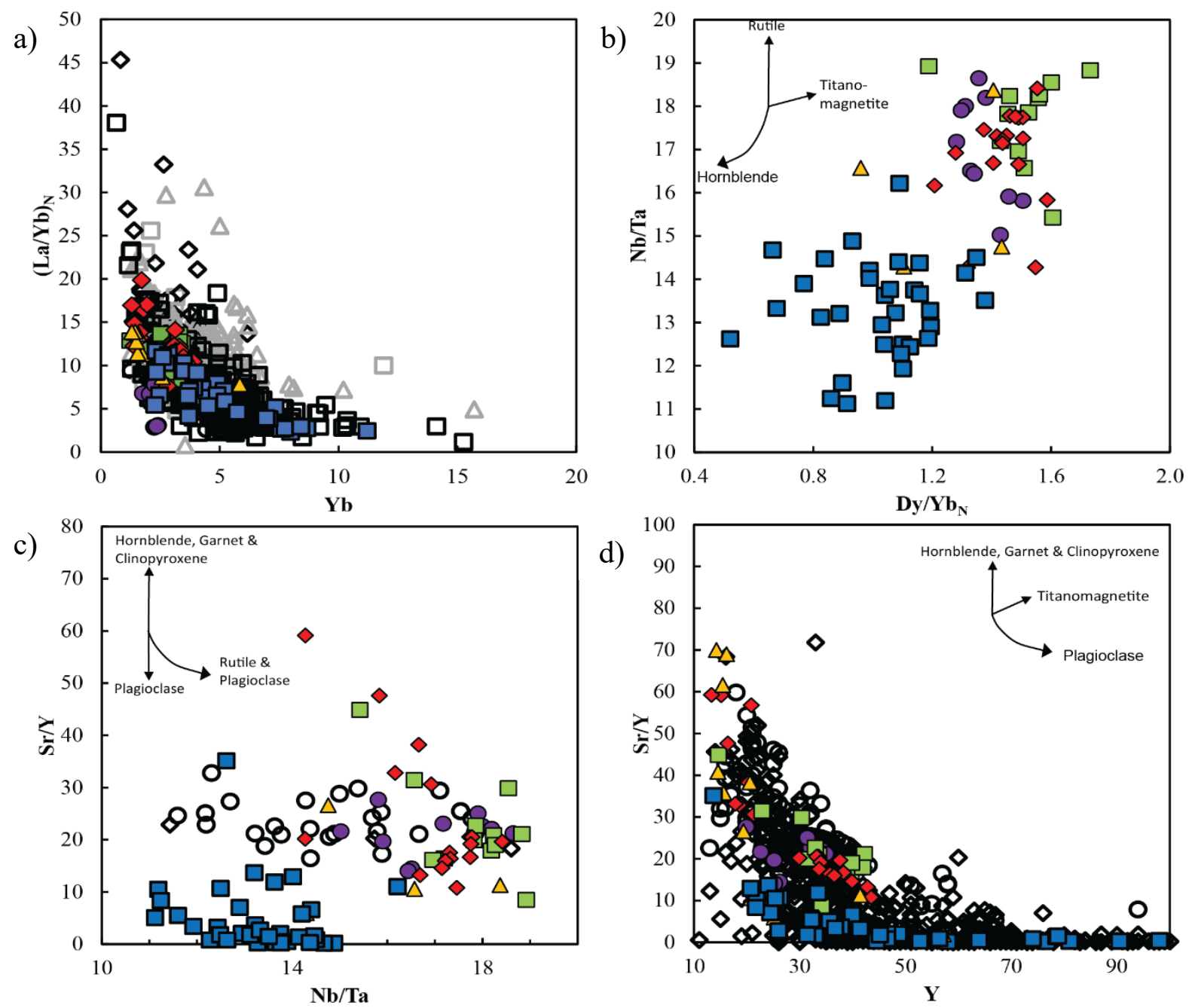

Figure 6. Bivariate trace-element ratio plots with fractionation trends: a) $(\mathrm{La} / \mathrm{Tb})_{\mathrm{N}}$ versus $\left.\mathrm{Yb} ; \mathrm{b}\right)$ $\mathrm{Nb} / \mathrm{Ta}$ versus $\mathrm{Dy} / \mathrm{Yb} \mathrm{b}_{\mathrm{N}}$; c) $\mathrm{Sr} / \mathrm{Y}$ versus $\mathrm{Nb} / \mathrm{Ta}$; d) $\mathrm{Sr} / \mathrm{Y}$ versus $\mathrm{Y}$. Same color scheme is used as figure 2 . 
a)

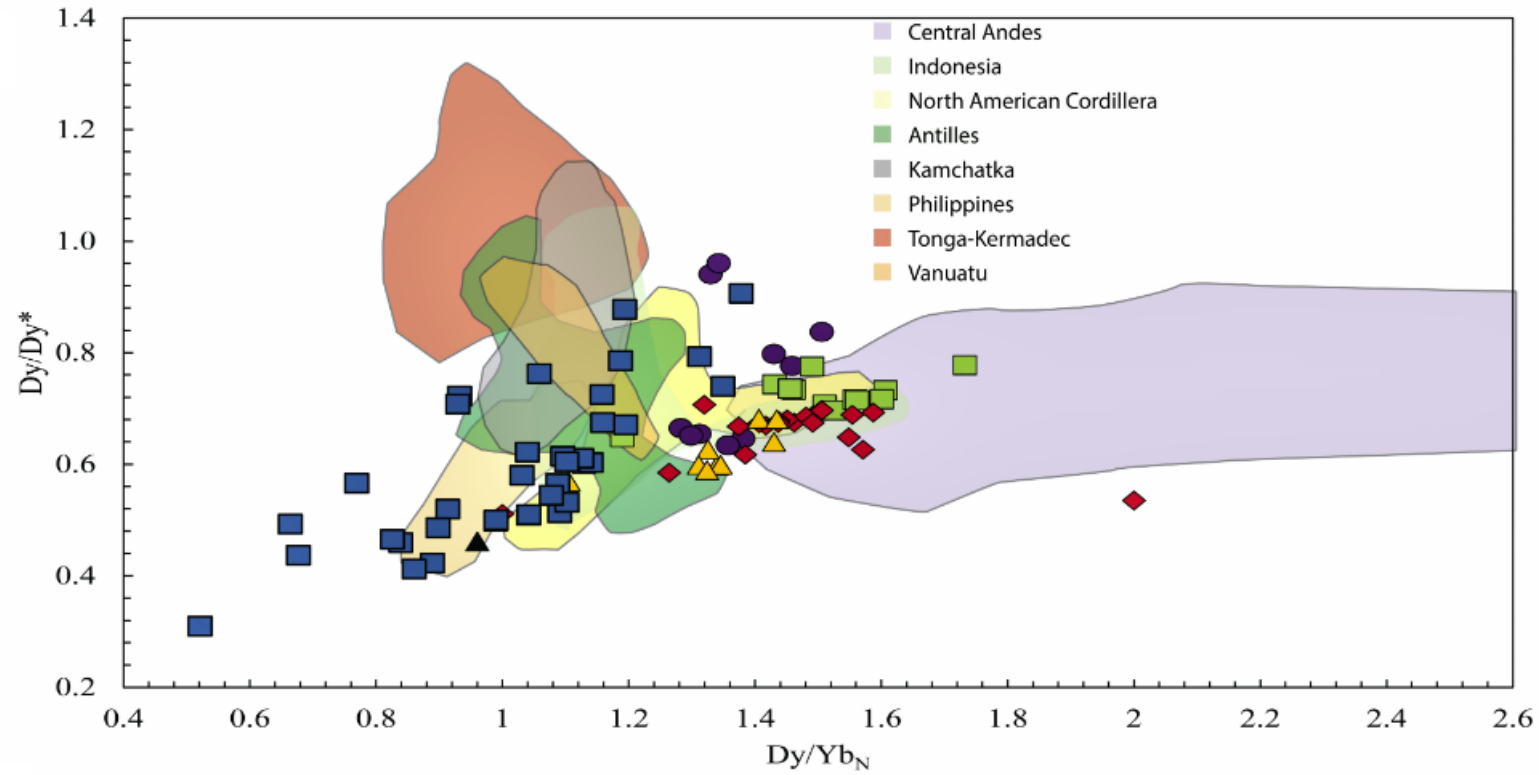

b)

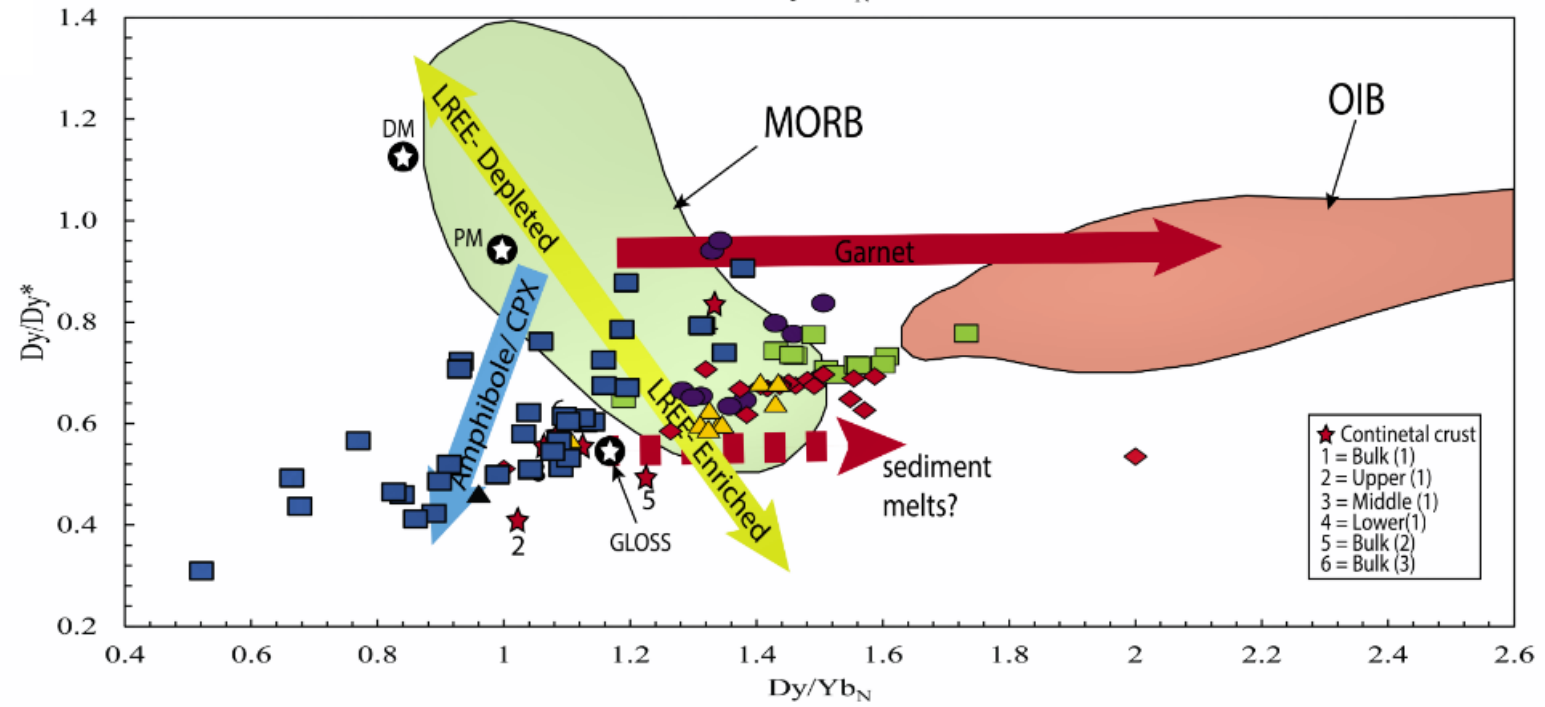

Figure 7. a) Dy/Dy* versus Dy/Y $\mathrm{b}_{\mathrm{N}}$ showing the relation of MDVF volcanic rocks with global island arcs and continental arcs. Majority of the volcanic rocks from the MDVF relate to a continental arc magmatic system. b) Dy/Dy* versus Dy/Y $\mathrm{b}_{\mathrm{N}}$ is used to display the source variation of MDVF volcanic rocks showing the relation between a MORB and OIB source as well as fractionation trends of amphibole/CPX, sediment melts, and garnet. The MDVF volcanic rocks follow a trend of LREE-enrichment and transition from an amphibole stable source to a garnet stable source. 
a)

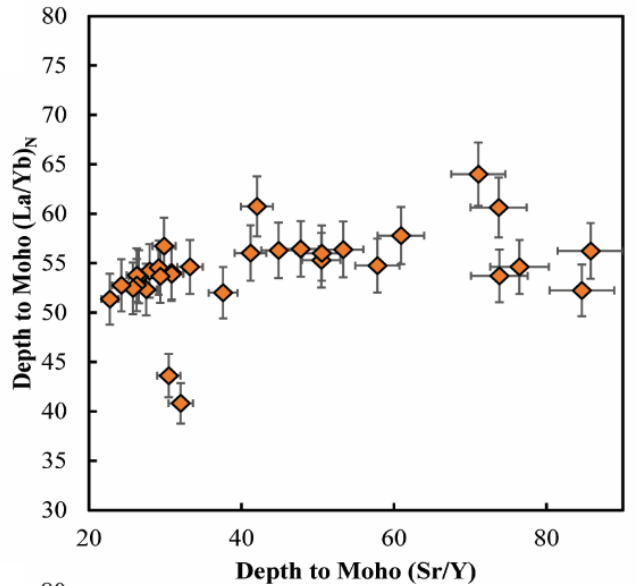

b)

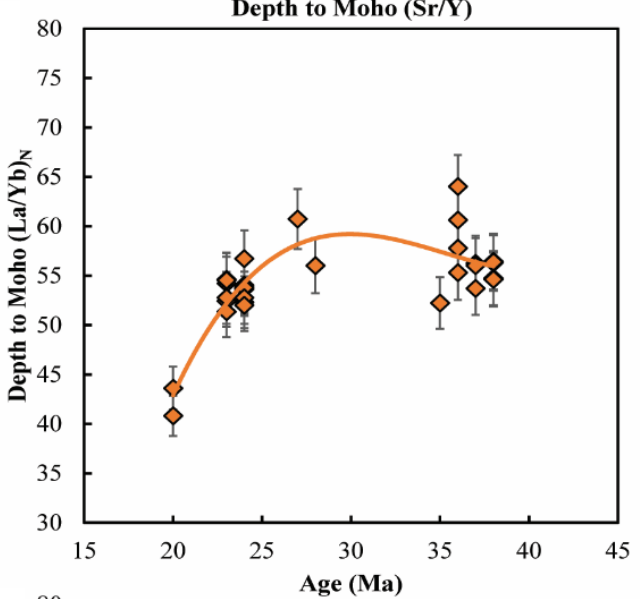

c)

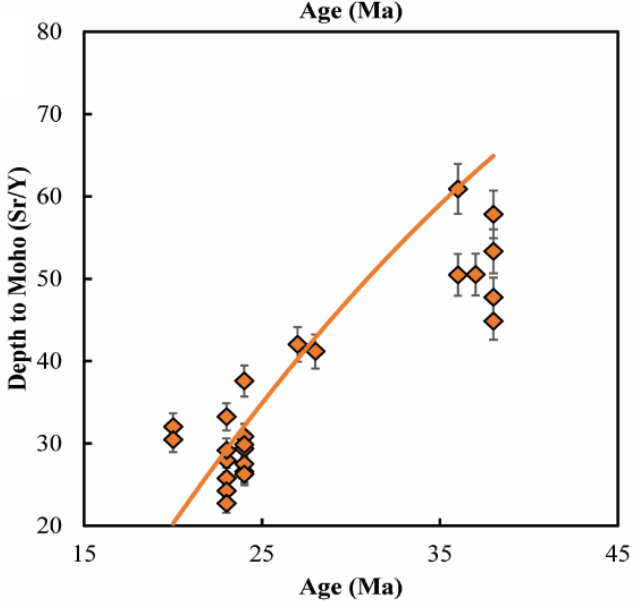

Figure 8. Whole-rock chondrite normalized $\mathrm{La} / \mathrm{Yb}$ and $\mathrm{Sr} / \mathrm{Y}$ ratio calculated crustal thickness for MDVF volcanic rocks over time. a) Comparison of crustal thickness calculations indicating that $\mathrm{Sr} / \mathrm{Y}$ related crustal thicknesses for intermediate composition rocks provide a general relationship to $(\mathrm{La} / \mathrm{Yb})_{\mathrm{N}}$, but typically result in thicknesses $\sim 20 \mathrm{~km}$ greater than those calculated by $(\mathrm{La} / \mathrm{Yb})_{\mathrm{N}}$. b) $\left.\mathrm{La} / \mathrm{Yb}\right)_{\mathrm{N}}$ calculated crustal thicknesses versus age. Thickness calculations suggest crustal thickness peaked around $28 \mathrm{Ma}$ and rapidly decreased in thickness around $25 \mathrm{Ma}$. c) $\mathrm{Sr} / \mathrm{Y}$ calculated crustal thicknesses versus age. $\mathrm{Sr} / \mathrm{Y}$ calculated thicknesses show a similar trend to $(\mathrm{La} / \mathrm{Yb})_{\mathrm{N}}$ thicknesses but peak in crustal thickness around $35 \mathrm{Ma}$. This dataset consisting of 1000 data points was filtered to include rocks with content between 55-68 wt \% $\mathrm{SiO}_{2}, \mathrm{Rb} / \mathrm{Sr}$ 
ratios between 0.05 and 0.2 , and $<4 \mathrm{wt} \% \mathrm{MgO}$. The resulting number of individual points after this filtering was decreased to 32 . This range of silica concentration was used to eliminate mafic rocks generated in the mantle, as well as high silica granites as suggested by Profeta et al. (2015). Additionally, outlier $(\mathrm{La} / \mathrm{Yb})_{\mathrm{N}}$ and $\mathrm{Sr} / \mathrm{Y}$ were removed statistically. Data with $\mathrm{Rb} / \mathrm{Sr}>0.2$ or $\mathrm{Rb} / \mathrm{Sr}<0.05$ were discarded to provide a trace-elemental filter for mantle-derived rocks or rocks formed by melting of pre-existing metasedimentary framework rocks, which could have been missed by the silica and magnesium filters (Chapman et al., 2015). Error bars are statistically calculated 5\% error. Chondrite normalization values are from McDonough and Sun (1995). 
a)

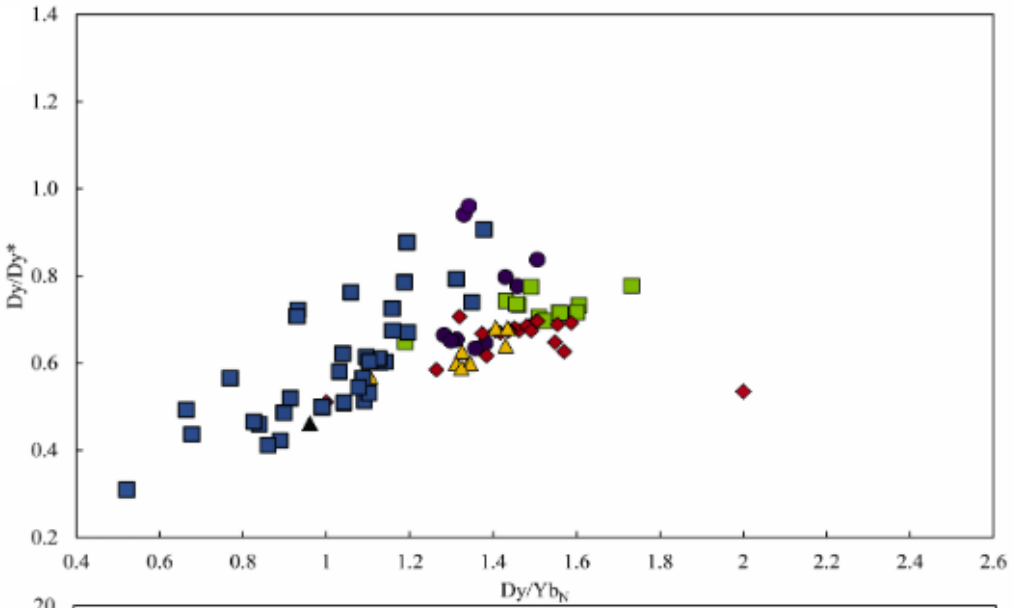

b)

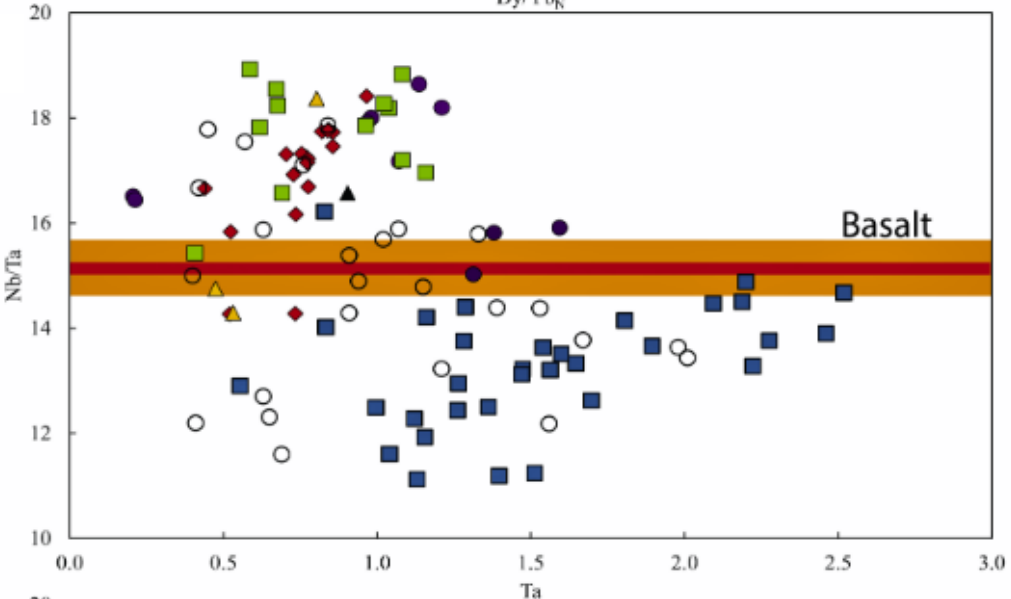

c)

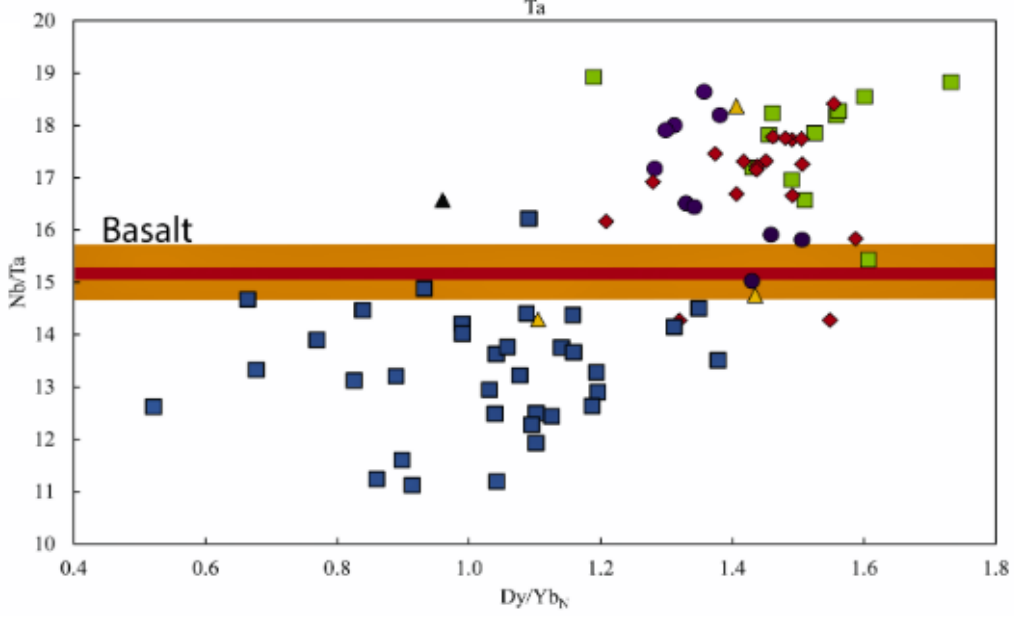

Figure 9. Bivariate trace-element ratio plots: a) Dy/Dy ${ }^{*}$ versus $\mathrm{Dy} / \mathrm{Yb}_{\mathrm{N}}$; b) $\mathrm{Nb} / \mathrm{Ta}$ versus $\mathrm{Ta}$; c) $\mathrm{Nb} / \mathrm{Ta}$ versus $\mathrm{Dy} / \mathrm{Yb}_{\mathrm{N}}$. 


\title{
MANUSCRIPT 2: PETROGENETIC EVOLUTION OF INTERMEDIATE MAGMAS
}

\author{
FROM THE MOGOLLON-DATIL VOLCANIC FIELD DURING ARC-RIFT \\ TRANSITION: INSIGHTS FROM WHOLE-ROCK GEOCHEMISTRY OF THE \\ BEARWALLOW MOUNTAIN ANDESITE
}

\begin{abstract}
The Mogollon-Datil volcanic field (MDVF) was the center of active volcanism during the ignimbrite flare-up and comprised of several pulses of caldera-forming ash-flow tuffs along with associated rhyolitic to basaltic lava flows and domes. Previous studies of MDVF volcanic rocks give significant attention to the large-volume ignimbrites and rhyolite flows as well as the minor basalt flows that occurred between 36 and $20 \mathrm{Ma}$, thus establishing an inherent bimodal trend. However, the petrogenesis of intermediate composition volcanism is still unclear and requires further investigation to understand how they play a role within the volcanic history of the MDVF. Here, we focus on the largest intermediate composition formation in the MDVF, the Bearwallow Mountain Andesite, in an effort to understand the petrogenesis of intermediate composition lava flows in the MDVF, and the petrologic conditions which allowed the transition from rhyolite to basaltic andesite between $28 \mathrm{Ma}$ and $23 \mathrm{Ma}$. Bearwallow Mountain Andesite lava flows are calc-alkaline phenocryst-poor basalts to trachyandesites. Whole-rock major-element compositions range from $48-63 \mathrm{wt} \% \mathrm{SiO}_{2}$ with $\mathrm{FeO}$ and $\mathrm{MgO}$ contents ranging from 5.2-10.5 wt $\%$ and 2.0-6.9 wt\%, respectively. REE patterns are enriched in LREEs compared to HREEs with $\mathrm{La} / \mathrm{Yb}$ ratios between 6.8-14.2 and Eu anomalies are moderately depleted. Petrological and geochemical variations between eruptive centers are likely explained by assimilation and fractional crystallization as the dominate processes in the petrogenesis of the magmatic system rather than magma mixing. The Bearwallow Mountain Andesite was likely source from subduction-modified lithospheric mantle and ascended via dike propagation during an extensional tectonic regime.
\end{abstract}

\section{Introduction}

During the mid-Tertiary, western North America was characterized by large-scale arc magmatism, episodic ignimbrite flare-ups, and rift-related bimodal volcanism. This established several volcanic fields extending from northern Mexico to the Colorado-Wyoming border. Initiation of these explosive eruptions and associated lava flows have a strong relation to the surrounding tectonic activity, as it plays an essential role in magma dynamics and the style of volcanism (Cather, 1990). Peak volcanic activity was suggested be contemporaneous with a 
regional-scale transition in tectonic regimes from Laramide-related crustal shortening to Basin and Range extension (Lipman et al., 1972). Initial interpretations of this relationship between magmatism and tectonism was deemed simple. However, with further investigation, the relationship has been questioned and there remains a considerable debate over the extent to which magmatism was affected by the transition in plate configuration.

In southwestern New Mexico, mid-Tertiary volcanism was centered upon the MogollonDatil volcanic field (MDVF) and was most active from the late Eocene through the early Miocene ( 36 to $24 \mathrm{Ma}$; McIntosh et al., 1992). Activity within the MDVF covered an estimated $40,000 \mathrm{~km}^{2}$ comprised of several pulses of caldera-forming ignimbrites along with associated rhyolitic to basaltic lava flows and domes. Understanding the volcanic and tectonic history of the MDVF has been an ongoing effort since the late 1950s (Jicha, 1954; Kuellmer, 1954; Tonking, 1957; Elston et al., 1975). Several mapping, geochemical, petrologic, and isotopic studies have contributed to resolving the stratigraphic framework of the MDVF in addition to the petrogenesis and source composition of the magma storage systems (for example, Elston et al., 1973; Chapin and Seagar, 1975; Ratté et al., 1984; McIntosh et al., 1992; Bikerman et al., 1990; Davis and Hawkesworth, 1993, 1994, 1995; McMillan, 1998; Chamberlin et al., 2004). Although there have been extensive research on the episodic ignimbrite eruptions within the MDVF, there has been little attempt to address the history of the large volumes of mafic to intermediate lavas associated with these explosive ash-flows. These intermediate composition lavas make up over half the volume of the MDVF and their origin and source is not clearly understood. Furthermore, the eruption of these mafic to intermediate lavas occur during the transition in tectonic regimes (30-20 Ma) from Laramide-related compression trigged from flat subduction of the Farallon plate to intercontinental extension. 
In this study, petrological and geochemical data is presented on the most widespread intermediate formation in the MDVF, the Bearwallow Mountain Andesite (BWA). These unusually crystal-poor lava flows of the BWA will be analyzed to better understand the broad compositional shift from rhyolite dominated volcanism to intermediate composition volcanism. This study aims to answer two questions: 1) What is the geochemical diversity of the BWA? 2) What petrogenetic process(es) and magmatic source produced the crystal-poor intermediate composition lava flows of the BWA? We suggest the crystal-poor magmas were produced by assimilation and fractional crystallization (AFC) processes in combination with crystal filtering of basalt through a remobilized crystal-mush.

\section{Geologic Setting}

The tectonic history of the southwest United States has significantly change over the course of the last 40 Ma with compressional stresses from subduction of the Farallon plate, to a within-plate extensional stress setting creating the horst-and-graben topography of the Basin and Range province. During the mid-Tertiary, large-scale calc-alkaline volcanism shaped the landscape up to $900-1200 \mathrm{~km}$ from the destructive plate margin (Davis et al., 1993). The largest stage magmatism was known as the "ignimbrite flare-up" and involved the ascent of melts into the lower and upper crust creating large volcano-plutonic complexes throughout western North America. This was suggested to correspond with the rollback and possible delamination of the Farallon plate as Laramide compression progressively dwindled, starting at $43 \mathrm{Ma}$ to $\sim 20 \mathrm{Ma}$ (Davis and Hawkesworth, 1994; McMillan et al., 2000; Farmer et al., 2007; Lipman, 2007). At 28.5 Ma, maximum crustal extension occurred in southern New Mexico, forming northwesttrending, moderately deep basins bounded by low-angle faults (Schneider and Keller, 1994). The 
rate of extension slowed down by $18 \mathrm{Ma}$ and re-accelerated between $9 \mathrm{Ma}$ and $3 \mathrm{Ma}$ forming north-south-trending block faults. The late-stage extension is associated with regional uplift, lithospheric thinning, and the eruption of true basaltic composition magmas (Baldridge et al., 1980). The tectonic relationship for the continuation of volcanism into the late-Oligocene is still debated on whether or not it relates to the rollback of the Farallon plate or the subsequent transition to an extensional regime, providing a massive ductile environment (Elston, 1984; Cather, 1990).

The Mogollon-Datil volcanic field (MDVF) is part of a discontinuous belt of midTertiary silicic volcanic fields and represents an ideal location to study the relationship between magmatism and tectonism during its arc-rift transition (Fig. 1). The MDVF is bounded by the Colorado Plateau to the north, the southern Basin and Range to the west, the Sierre Madre Occidental to the south, and the Rio Grande Rift to the east. Volcanism began at $43 \mathrm{Ma}$ and was most active during the "ignimbrite flare-up" between 36-24 Ma (McIntosh and Bryan, 2000). Geophysical expressions of the MDVF shows a regional Bouguer gravity anomaly low of $\sim 40$ mGals and an aeromagnetic high that is interpreted to be batholith that likely fueled the large caldera-forming eruptions (i.e. Bursum caldera; Ratté et al., 1984). The stratigraphic framework of the regional ignimbrites erupted within the MDVF continues to be updated using more precise and accurate ${ }^{40} \mathrm{Ar} /{ }^{39} \mathrm{Ar}$ geochronology techniques (i.e. McIntosh et al., 1992; Chamberlin, 2004). These ignimbrites derived from 4 episodic pulses, each separated by a hiatus, known as the First Flare-Up (36.2-33.5 Ma), Short Burst (32.1-31.4 Ma), Big Doublet (29.0-27.4 Ma), and Last Gasps (26.1-24.3 Ma; McIntosh et al., 1992). These well-studied ignimbrites have been correlated to 12 source calderas located in New Mexico (as many as 28 calderas have been identified; Chamberlin et al., 2004). Three of the four pulses also correlate with volcanism in the 
San Juan volcanic field in Colorado and the Sierra Madre Occidental in Mexico, implying a similar tectonic control (Nieto-Samaniego et al., 1999; Lipman, 2007; Best et al., 2016).

In between these large-scale eruptions, lava flows and domes erupted ranging from rhyolitic to basaltic in composition. These discontinuous lava flows make up a large volume of the MDVF and have been broadly classified into 3 distinct periods based on geochemical and isotopic characteristics, known as pre-30 Ma Laramide-related arc magmatism, 30-20 Ma arctransitional magmatism, and post-20 Ma Rio Grande rift magmatism (Davis and Hawkesworth, 1993, McMillan, 1998). Each temporal group has a unique style of volcanism and are suggested to derive from separate sources that reflect the transition in tectonic regimes. The overall progression of these lava flows transition from predominantly crystal-rich rhyolites and dacites (pre-30 Ma) to more intermediate composition volcanic rocks (30-20 Ma) and conclude with low volume basalt flows (post-20 Ma). Although the term "bimodal" volcanism is commonly used to describe the volcanics in the MDVF, there clearly exists a full compositional range, with a complete record from rhyolite to basalt, with a significant volume of intermediate compositions.

The distinct period between 30-20 Ma within the MDVF is arguably one of the most complex and least understood intervals of time with respect to understanding how tectonics of the local area have influenced the style of volcanism (e.g. subduction-related versus extensional), understanding the location of the magmatic source(s), and how these transitional magmas evolved relative to the episodic high-silica ignimbrite eruptions (Bikerman et al., 1990; McIntosh et al., 1992; Davis and Hawkesworth, 1993, 1995). Furthermore, the elusive crystal-poor nature of the intermediate lava flows within the MDVF adds confusion to their petrogenesis as they don't fit the typical petrologic mechanisms to produce andesites (Kent, 2016). Therefore, added 
attention is needed to this group to further constrain the geologic history and integrate it into the volcanic timeline of the MDVF.

\section{Methods}

Sample Collection. A total set of 80 bulk rock samples were collected from Bearwallow Mountain Andesite (BWA) lava flows. A broad east to west sampling transect was performed across the MDVF in order to understand the processes of differentiation and the geochemical nature of the parental magmas. A range of lava compositions were collected from three vent locations: O-Bar-O Mt, Pelona Peak, and Bearwallow Mountain. Additional samples were acquired from the surrounding exposed outflow sheets near John Kerr Peak within the Tularosa Mountains, Telephone Canyon, and north of the Francisco Mountains. This allowed constraints to be placed on the chemical variation of the BWA across the MDVF. All the designated outcrops were sampled in-situ. Each sampling location was thoroughly studied and documented by acquiring a number of representative unaltered samples, GPS coordinates, and a record of megascopic mineral and textural descriptions. Sample locations that exposed clear and distinct stratigraphic sections of deposited BWA lava flows were described in more detail. Samples were collected at multiple elevations of each stratigraphic column to observe systematic variation within the unit.

Analytical Procedures. Thin sections were made for each sample and analyzed using standard point-count methods with the use of a petrographic microscope. Bulk rock major- and trace-elements (Sc, V, Cr, Ni, Zn, Rb, Sr, Y, Zr, Nb, Ba, Pb, and Th) were obtained on 20 BWA samples by standard X-Ray fluorescence (XRF) spectrometry at Washington State University's Peter Hooper GeoAnalytical Laboratory, Pullman, Washington, using a ThermoARL Advant'XP 
+ sequential X-ray fluorescence spectrometer using the methods described in Johnson et al.

(1999). Analysis of trace-element contents, including the rare-earth elements, were performed on 20 samples by inductively coupled plasma-mass spectrometry (ICP-MS) at Washington State University's Peter Hooper GeoAnalytical Laboratory using an Agilent Technologies 7700 ICPMS following the protocol of Jarvis (1988) and Johnson et al. (1999). Sample location and GPS coordinates are listed in Table 1.

\section{Results}

Field Relations of the Bearwallow Mountain Andesite. The Bearwallow Mountain Andesite (BWA) is one of the most widely distributed volcanic units, thus making the region predominately intermediate in composition. The BWA erupted out of small volume shield/stratocone volcanoes $\left(1-10 \mathrm{~km}^{3}\right)$ primarily in the west-central and northern MogollonDatil Volcanic Field (MDVF) stretching across the Mangas Mountains, Tularosa Mountains, and the Mogollon Mountains. Due to the vast abundance of mid-Tertiary volcanics, the New Mexico Bureau of Geology and Mineral Resources divided the region into six major units (T1 through T6, Clemons, 1983). The BWA is part of the T4a sequence and stratigraphically overlies older pre-30 Ma volcanic units, comprised mainly of large ignimbrite ash-flow tuffs and rhyolitedacite flows (T3). The BWA is capped with minor rhyolitic-dacitic (T5r) and basaltic flows (T6b) that erupted during mid- to late-Miocene and Pliocene.

Surrounding the margins of the MDVF exist large fault-bounded uplifted basement blocks made up of metabasic volcanics, metaquantizes, and politic schists (exposed south of Silver city). Paleozoic limestones, sandstones, and shales are deposited on top of the 
Precambrian $(1.7 \mathrm{Ga})$ basement rock and are intruded by pre-Tertiary granodiorite and quartz monzonite plutons (Davis et al., 1993).

Exposures of the BWA vary from hackly fractured massive flows that are scoriaceous in nature to cleaved flows. The BWA displays a uniformly dark grey-black color and contrasts the strongly porphyritic andesite character of the older pre-30 Ma intermediate lavas (i.e. Rubio Peak and Palm Park formations). This is supported by its significantly crystal-poor nature with an average phenocryst content of $\sim 10 \%$. The majority of the samples are aphyric and vesicular with phenocrysts of plagioclase, clinopyroxene (cpx), orthopyroxene (opx), and olivine (iddingsite; Fig. 2). Fe-Ti oxides occur as a minor phase and are more abundant within the basaltic andesites. The mafic mineral assemblage within the BWA appear to be more anhydrous (absence of visible hornblende and biotite phenocrysts) relative to older andesite-basaltic andesite units (T3a-T2). Several of the exposed outcrops have calcite and quartz filled vesicles as a result of secondary alteration.

Petrography and Mineral Chemistry. Plagioclase (3-40\%) is the dominant mineral phase, confined mainly to the groundmass and range in composition between labradorite and andesine. Two populations of plagioclase are observed within the BWA samples. Type one population is characterized by subhedral grains $0.5 \mathrm{~mm}-1 \mathrm{~mm}$ in length and are acicular to bladed in shape. Type one make up the majority of the groundmass with large grains displaying Carlsbad or polysynthetic twinning with little to no zoning profiles. The oldest andesite (BWA 5) and the youngest basalt (BWA 30) samples were significantly more crystal-rich (20-30\%) and contained plagioclase (type two) with complex zoning profiles, sieving, and resorption textures, resembling textures observed in pre-30 Ma andesites and post-20 Ma basalts (Davis and Hawkesworth, 1995). The type two plagioclase grains are larger, ranging from 1-3mm and are 
more tabular. These two unique samples also contain glomerocrysts of plagioclase and pyroxene, suggesting a xenolithic origin.

Both cpx $(<5 \%)$ and opx $(<5 \%)$ are anhedral to subhedral. The majority of the $\mathrm{cpx}$ consist of augite $(0.5-1 \mathrm{~mm})$ with few showing overgrowth rims of opx. The opx comprise mainly of enstatite and hypersthene (0.5-3mm). Both cpx and opx display red-brown colored rims resulting from oxidation. The majority of the olivine phenocrysts were weathered to iddingsite, altering from the rim to the core, and displayed the characteristic red-brown color. The anhedral olivine was less prevalent in the older andesites and more abundant in the basaltic andesites with the highest percentages within samples near John Kerr Peak and within the basalt north of the Francisco Mountains.

The groundmass consisted primarily of plagioclase microlites with intergranular hypersthene, iddingsite, glass, and Fe-Ti oxides. The relatively older andesites from Pelona Peak consist of a glassy matrix with smaller microlites of plagioclase. The older, less evolved BWA samples from Telephone Canyon and John Kerr Peak consisted of larger plagioclase microlites with broken up olivine that filled the interstitial spaces.

Whole-Rock Major-Element Geochemistry. The Bearwallow Mountain Andesite (BWA) suite ranges in $\mathrm{SiO}_{2}$ from 48 to $63 \mathrm{wt} \%$ and total alkalis $\left(\mathrm{Na}_{2} \mathrm{O}+\mathrm{K}_{2} \mathrm{O}\right)$ from 4 to $7 \mathrm{wt} \%$ (Fig. 3; Table 1). The BWA can be classified into three groups: (1) andesite-trachyandesite (57$\left.63 \mathrm{wt} \% \mathrm{SiO}_{2}\right),(2)$ basaltic andesite-basaltic trachyandesite $\left(52-57 \mathrm{wt} \% \mathrm{SiO}_{2}\right)$, and (3) basalt ( $\sim 8 \mathrm{wt} \% \mathrm{SiO}_{2}$; Le Bas et al., 1986). The highest silica andesite $\left(\mathrm{SiO}_{2} \sim 63 \%\right)$ may be associated with the Bear Springs Formation, making it part of the upper T3a lavas (Davis and Hawkesworth, 1993). The outlier true basalt making up group 3 has a similar composition to the late-Tertiary post-20 Ma basalt flows (Davis and Hawkesworth, 1995), and thus could represent 
the cap of the BWA. Whole-rock composition of the BWA varies with stratigraphic position with more evolved andesitic rocks underlying younger basaltic rocks. The higher silica andesites in group 1 tend to locate around the vent locations of O-Bar-O and Pelona Peak. The more basaltic andesites of group 2 and 3 were located near John Kerr Peak, Telephone Canyon, and north of the Francisco Mountains.

BWA samples show a general inverse variation versus $\mathrm{SiO}_{2}$ for $\mathrm{MgO}, \mathrm{CaO}, \mathrm{FeO}$, and $\mathrm{TiO}_{2}$, and a direct relationship with $\mathrm{Na}_{2} \mathrm{O}$ and $\mathrm{K}_{2} \mathrm{O}$ (Fig. 4). The BWA shows a wide range of $\mathrm{MgO}$ contents from 2-6.8\%. Group 2 basaltic andesites have the most range in Mg\#'s $(\mathrm{MgO} /(\mathrm{MgO}+\mathrm{FeO}))$ ranging from $30-49$, with lower values resulting from higher total iron contents. The more evolved group 1 andesites have Mg\#'s between $42-48$ and the true basalt has the highest $\mathrm{Mg} \#$ of 54 . The $\mathrm{Al}_{2} \mathrm{O}_{3}, \mathrm{Na}_{2} \mathrm{O}, \mathrm{P}_{2} \mathrm{O}_{5}$, and $\mathrm{MnO}$ contents show little variation between each of the groups for a given $\mathrm{SiO}_{2} \cdot \mathrm{TiO}_{2}$ and $\mathrm{CaO}$ contents are higher in low $\mathrm{SiO}_{2}$ groups ranging between $1.2-2 \%$ and $6-10 \%$, respectively. $\mathrm{K}_{2} \mathrm{O}$ is relatively high, ranging from $2-3.1 \%$ in groups 1 and 2. Therefore, the BWA can be considered a high-K, calc-alkaline series and fits a near-linear calc-alkaline trend (Fig. 3). The true basalt in group 3 has significantly lower $\mathrm{K}_{2} \mathrm{O}$ content of $0.7 \%$, thus isolating it as a distinct group.

The majority of the intermediate volcanic rocks plot near the sub-alkaline field and $\mathrm{SiO}_{2}$ contents range between 51 and 56 wt.\% for molar $\left(\mathrm{Na}_{2} \mathrm{O}+\mathrm{K}_{2} \mathrm{O}\right)-\mathrm{CaO}$, defining the suite as alkali-calcic (alkali lime index of 51; Peacock, 1931). The BWA series straddles between the tholeiitic and calc-alkaline fields of Miyashiro (1974; Fig. 3). The more mafic end-members (group 2) tend to be more tholeiitic and similar to Rio Grande rift basalts (Davis and Hawkesworth, 1995). 
Whole-Rock Trace-Element Geochemistry. The calc-alkaline BWA rocks show a relatively homogenous "arc-like" trace-element signature within groups 1 and 2 (Table 2; Fig. 5). This is indicated by large ion lithophile elements (LILE; e.g. $\mathrm{Ba}=808-1358$ ppm) and light rareearth element (LREE; e.g. $\mathrm{La}=39-64 \mathrm{ppm}$ ) enrichment relative to average chondrite with strong negative anomalies for $\mathrm{Nb}-\mathrm{Ta}$ and Ti contents (Fig. 5b). The high field strength elements (HFSE) are relatively less abundant, with $\mathrm{Nb}$ contents between 7-21 ppm. Therefore, the BWA series have high LILE/HFSE $(\mathrm{Ba} / \mathrm{Nb})$ and LREE/HFS $(\mathrm{La} / \mathrm{Nb})$ ratios, with $\mathrm{Ba} / \mathrm{Nb}=41-122 \mathrm{ppm}$ and $\mathrm{La} / \mathrm{Nb}=2.1-4.1$.

Using Davis and Hawkesworth (1993) trace-element classification methods, both compatible and incompatible element concentrations show wide variations in BWA rocks. Group 1 rocks have lower concentrations of compatible elements, with $\mathrm{Ni}=\sim 52 \mathrm{ppm}$ in the andesites and increasing to $\mathrm{Ni}=\sim 78 \mathrm{ppm}$ in the basaltic andesites. Basaltic andesites of John Kerr Peak have unusually low concentrations of compatible elements, $\mathrm{Ni}=\sim 52 \mathrm{ppm}$. Group 3 had the highest concentration of compatible elements, $\mathrm{Ni}=88 \mathrm{ppm}$ and $\mathrm{V}=213 \mathrm{ppm}$. Incompatible element concentrations are relatively high in groups 1 and 2, with both $\mathrm{Ba}$ and $\mathrm{Sr}>600 \mathrm{ppm}$. Again, the basaltic andesites of John Kerr Peak contrast significantly with the other group 2 basaltic andesites in that it had the highest incompatible element concentrations, $\mathrm{Ba}$ and $\mathrm{Sr}>$ $1250 \mathrm{ppm}$. The true basalt has $\mathrm{Ba}$ and $\mathrm{Sr}<550 \mathrm{ppm}$. Therefore, incompatible elements generally increase from the more basaltic andesites to the andesites.

With the exception of the true basalt, the trace-element ratios of group 1 and 2 are consistent with lavas being classified as 'orogenic' according to Davis and Hawkesworth (1993) who classified 30-20 Ma intermediate rocks within the MDVF. Using trace-element constraints from McMillan (1998) to separate arc-derived from non-arc derived magmas, group 1 and 2 plot 
below the $\mathrm{Nb} / \mathrm{Ba}=0.0323$ slope line (Fig. 6) and can be classified as subduction-modified lithosphere (LSUBD). Group 3 plots above the $\mathrm{Nb} / \mathrm{Ba}=0.0507$ slope line and is classified as an asthenosphere basalt. The true basalt is also consistent with EM-type OIB trace-element ratios $\mathrm{Nb} / \mathrm{Pb}=14, \mathrm{Ce} / \mathrm{Pb}=23, \mathrm{~K} / \mathrm{U}=10046, \mathrm{~K} / \mathrm{Nb}=284, \mathrm{Nb} / \mathrm{Th}=9.8$ (Sun and McDonough, 1989). Thus, the group 3 basalt may be unrelated to the BWA series but suggests the evolutionary pathway to the younger OIB-like volcanic rocks.

Garnet commonly incorporates heavy REEs while amphibole preferentially incorporates middle REEs over heavy REEs. As a result, garnet fractionation will increase $\mathrm{Dy} / \mathrm{Yb}$, while amphibole fractionation will decrease $\mathrm{Dy} / \mathrm{Yb}$ (Macpherson et al., 2006). Plotting the BWA series on the trace-element ratio plot of $\mathrm{Dy} / \mathrm{Yb}$ vs. $\mathrm{SiO}_{2}$ shows a moderate depletion of Dy relative to $\mathrm{Yb}$ within group 1 and progresses to slightly higher $\mathrm{Dy} / \mathrm{Yb}$ ratios. This suggests an amphibole phase was stable within older BWA magmas and transitioned to a more pyroxene or garnet stable source. A moderate dip in the middle REE is also indicative of a stable amphibole phase that may have been present either at the source or within a subsequent reservoir (Fig. 5a). Relatively high $\mathrm{La} / \mathrm{Yb}$ ratios are also consistent with garnet instability for the majority of the BWA samples (Fig. 7b). Group 3 has a significantly lower $\mathrm{La} / \mathrm{Yb}$ ratio supporting that it is likely more related to the younger rift basalts indicating a deep mantle source with enrichment of REE's.

Group 1 and group 2 show moderate to low $\mathrm{Eu}^{*}$ anomalies with a progressive decrease towards the more basaltic samples (Fig. 7d). Group 3, an outlier, had a positive Eu* anomaly indicating plagioclase accumulation. $\mathrm{Rb} / \mathrm{Sr}$ ratios generally decrease with increasing $\mathrm{Sr}$ concentrations with the exception of the group 3 basalt (Fig. 7c). The Rb enrichment also corresponds to the lower Eu* anomalies. This suggest that group 1 and group 2 were derived 
from a similar source, moving from lower crustal compositions to the lithospheric mantle. Both of these groups lie on the same petrogenetic trend consistent with mineral fractionation from a more basaltic melt. The true basalt deviates from this trend shown by a decrease in $\mathrm{Sr}$ content and indicates a different source.

$\mathrm{Nb} /$ Ta ratios are unusually high, with values ranging between 16-19 (Fig. 7a). These ratios are distinctly higher than $\mathrm{Nb} / \mathrm{Ta}$ ratios in the continental crust (12-13) and in the bulksilicate Earth (BSE: 14). The trend shows a broad curve from a relatively lower $\mathrm{Nb} / \mathrm{Ta}$ ratio in the older BWA sample (BWA 5) and arcs upward during the 30-20 Ma transitional period with the highest $\mathrm{Nb} / \mathrm{Ta}$ ratios in the basaltic andesites. The trend slightly curves back down to a value of about 16 , marked by the true basalt (BWA 30 ) and aligns with typical $\mathrm{Nb} / \mathrm{Ta}$ ratios of ocean island basalt (15-16). This implies that the lithospheric mantle may be contributing to the high $\mathrm{Nb} / \mathrm{Ta}$ ratios observed in the majority of the BWA samples.

Trace-element discrimination diagrams were used to identify the tectonic environment of the BWA series. Using Pearce and Cann (1973) Ti-Zr-Y diagram, group 1 and 2 plotted in the calc-alkaline field while group 3 plotted in the within-plate basalt field. Furthermore, this was confirmed using Pearce (1982) Ti/Y-Nb/Y discrimination diagram. Group 3 plotted within the transition field between tholeiitic and within-plate alkali basalt.

\section{Discussion}

Origin of the Crystal-Poor Bearwallow Mountain Andesite. To constrain the evolutionary pathway of the BWA and to identify the potential source reservoir(s), three petrogenetic models are proposed: (1) simple binary mixing of one or more magmas with the continental crust; (2) equilibrium fractional crystallization (FC) of basaltic end-members; (3) 
assimilation of crustal derivatives combined with fractional crystallization (AFC). Each of these magmatic scenarios were evaluated for geologic validly to provide the appropriate petrogenesis of the BWA.

Magma Mixing. Subduction-related magmas often involve magma mixing processes as the dominant mechanism to generate andesitic compositions (Annen et al., 2006; Straub et al., 2015; Kent, 2016). However, the BWA petrographically shows little to no evidence for magma mixing playing a dominant role in its petrogenesis. In terms of macro-textures, there were no signs of mixing of two or more end-members (i.e. flow structures and/or magmatic enclaves). At the micro-scale, if magma mixing was prevalent, we would expect to find re-melting/resorption textures, complex mineral zoning, sieving, multiple melt compositions, and a significant glomerocryst population, indicating hybridization of crystal-bearing magmas (crystal-rich mushes) of different bulk compositions (Perugini and Poli, 2012). However, no such evidence was found in the BWA lava flows, with the exception of the post-20 Ma true basalt and the high silica andesite suggested to be pre-30 Ma from the Bear Springs Formation.

A variety of mixing models were considered between a composition similar to the more evolved andesites in group 1 (BWA 12) and the least evolved BWA sample (BWA 30), similar to the post-20 Ma rocks. Using trace-element compositions, these two sources were mixed using $10 \%$ increments. The results were plotted on ratio diagrams for $\mathrm{Nb} / \mathrm{La}$ versus $\mathrm{Ba} / \mathrm{Nb}$ and $\mathrm{Ba} / \mathrm{Th}$ versus $\mathrm{Ba} / \mathrm{Ta}$ to illustrate the validity of the model. BWA magmas fit the calculated mixing trend requiring $30-55 \%$ mixing of an OIB-like end-member mixed with the high silica andesite to reproduce the andesites and basaltic andesites (Fig. 8a). BWA magmas also fits the overall geochemical progression from more evolved andesites during pre-30 Ma to the least evolved rocks during post-20 Ma. Although these results may suggest mixing as a viable mechanism, it 
should be noted that caution must be taken when modelling, as any two sources may potentially show an inherent relationship if mixed (Kent et al., 2010). Using ratios of $\mathrm{Ba} / \mathrm{Th}$ versus $\mathrm{Ba} / \mathrm{Ta}$ as further constraints, it is apparent that the mixing trend fails to model the petrogenesis of the BWA (Fig. 8b). Mixing shows a relatively linear trend while the BWA rocks and temporal groups taken from Davis and Hawkesworth (1995) show a curved trend above the mixing line. Furthermore, mixing a source from post-20 Ma with a source from pre-30 Ma to produce the andesites and basaltic andesite during 30-20 Ma can be problematic. The timeline of magma generation of the BWA is relatively long and thus, may have mixed with compositions similar to post-20 Ma rocks.

Therefore, if mixing is occurring, it is likely between melts with very similar compositions and temperatures (e.g. not mixing a basalt and rhyolite). Mixing may have played a role in triggering eruption, but likely was not a major factor during differentiation of the BWA melts. A more likely scenario may involve magmas with a composition similar to post- $20 \mathrm{Ma}$ rocks assimilating pre-30 Ma rocks.

Fractional Crystallization. The following initial observations of major-element trends of the calc-alkaline BWA series gave strong evidence for fractional crystallization (FC): (1) Increase in $\mathrm{Na}_{2} \mathrm{O}$ and $\mathrm{K}_{2} \mathrm{O}$ and decrease in $\mathrm{FeO}, \mathrm{CaO}, \mathrm{MgO}$, and $\mathrm{MnO}$ contents are compatible with fractional crystallization processes; (2) Decrease in $\mathrm{Al}_{2} \mathrm{O}_{3}, \mathrm{CaO}, \mathrm{MgO}, \mathrm{Fe}_{2} \mathrm{O}_{3}$, and $\mathrm{Sr}$ with increasing silica contents are associated with plagioclase, amphibole, and pyroxene fractionation during crystallization of magma: (3) $\mathrm{Sr}$ and Eu display negative trends with increasing silica content (Parlak, 2006); (4) $\mathrm{TiO}_{2}$ shows a steep negative trend in addition to a pronounced negative $\mathrm{Ti}^{*}$ anomaly in the REE diagram indicating strong fractionation of magnetite and/or amphibole, as they are both preferentially saturated early in arc-related magmas (Sisson and 
Grove, 1993). Furthermore, petrographic observations of the BWA, consisting of uniform textures, euhedral to subhedral grains, and simple zonation profiles, are indicative of fractional crystallization.

Simple unconstrained major-element equilibrium FC modelling was performed first to see if it provided a close approximation of the BWA samples. Due to the fact that the majority of the BWA is relatively differentiated, the least evolved basaltic andesite was used to represent the initial composition to avoid uncertainties in the primitive source. Major-element fractional crystallization was done in $2 \%$ increments crystalizing olivine, clinopyroxene, orthopyroxene, plagioclase, Ti-rich amphibole, apatite, and Mn-Fe-Ti oxides using methods and equations from Rollinson (1993). During each step, the fraction removed per phase was aided by observed petrographic modal assemblages. A total of $40 \%$ of the melt was extracted and gave a relatively close approximation to BWA compositions. BWA 30 and BWA 5 tend to be outliers representing the caps of the BWA, as they are believed to be associated with separate lava flows during different time periods.

To test the plausibility of fractional crystallization, a more comprehensive mass-balanced approach using IgPet software was used. Using methods from Bryan et al. (1969), least squares regression of the major-elements was performed using a parental magma that was basaltic andesite in composition with trace-element compositions similar to pre-30 Ma rocks (BWA 5). Each of the oxides were weighted to reduce the effect of the high $\mathrm{SiO}_{2}$ and $\mathrm{Al}_{2} \mathrm{O}_{3}$ contents. Comparing the difference between the observed data of the BWA series and the predicted values after fractionating plagioclase, clinopyroxene, olivine, and magnetite, the residual sum of squares gave a best-fit value of 0.418 with a required fractionation of $31 \%$. Thus, fractional 
crystallization appears to be a viable process; however, it requires a relatively high amount of fractional crystallization to produce the daughter composition.

Trace-element compositions of the BWA were used to construct FC models to see if they produced similar results comparable to the major-elements (Fig. 9). Trace-element partition coefficients were used from Arth (1976) and Fujimaki et al. (1984) who did experimental work on basaltic and basaltic andesite liquids. Bulk distribution coefficients (D) were calculated using a mineral assemblage of $60 \%$ plagioclase, $16 \%$ clinopyroxene, $10 \%$ orthopyroxene, $6 \%$ olivine, and $8 \%$ magnetite. Similar to the major-element FC models, the more primitive BWA samples were first chosen to be used as the starting compositions. Of the various combinations of initial starting conditions for the BWA magmas within these relatively unconstrained end-member models, the best fit to the experimental points involved a parental magma with a composition similar to pre-30 Ma volcanic rocks (BWA 5). The least evolved basaltic andesites within the southern region of the Tularosa Mountains in Telephone Canyon (BWA 24, 25) were also observed to produce a good fit to the data as initial starting compositions. The required amount of fractionation was between $30-60 \%$ to reproduce the BWA sample points.

Assimilation-Fractional Crystallization. Pure FC models replicate the data well, however, it requires a substantial amount of fractionation. This becomes problematic when trying to chemically justify differentiation from basaltic andesite to andesite with such large fractionation percentages. Davis and Hawkesworth (1993) attempted to model the 30-20 Ma andesites and basaltic andesites through fractional crystallization using major-elements and produced a similar result of $37 \%$ fractionation of olivine, augite, plagioclase, and magnetite (14:30:49:8). In addition to large percentages of fractionation, the trend only fit the trace-element variations of the low-silica andesites. Davis and Hawkesworth (1993) used mixing as a viable processes to 
explain the second trend of the high-silica andesites and dismissed the idea of AFC. The reason why contamination through $\mathrm{AFC}$ processes was rejected was due to the decrease in Ba content with increasing $\mathrm{Rb}$, stating that $\mathrm{Ba}$ was incompatible in all observed phenocryst phases. Thus, fractional crystallization would only drive the Ba concentration up and would therefore require an unrealistic assimilation rate of a low-Ba source. However, Ba does partition into Ca-rich plagioclase causing Ba to decrease (Blundy and Wood, 1991). The initial rise in Ba likely resulted from plagioclase fractionation at depth which later became stable causing a decrease in $\mathrm{Ba}$. The presence of amphibole can cause Ba to partition into a phenocryst phase, and although not directly observed, it may play an essential role in the petrogenesis of BWA magmas. Therefore, a stable amphibole phase is inferred to be present as a residual in melting and contamination processes at depth rather than directly fractionating before eruption. This would result in cryptic signatures that may not be easily observed in the volcanic rocks. The Last Chance Andesite and Mineral Creek Andesite have similar compositions to the BWA in addition to similar eruption times (Oehring et al, 2017). These more evolved andesites show an abundance of amphibole and may share a similar source with the BWA (Oehring et al, 2017).

To reduce the exceedingly large amount fractionation needed to generate the BWA magmas, small volumes of wall rock was likely assimilated into the melt during its differentiation pathway to the Earth's surface. This was tested using the AFC model of DePaolo (1981; Fig. 9). Bulk distribution coefficients (D) were calculated using the same mineral assemblage tested in the FC models. Average continental crust was used as the assimilant from Weaver and Tarney (1984). A range of values were simulated for the degree of assimilation (r), determined by the rate of mass assimilation divided by the rate of fractional crystallization (lower $r$ values imply that the chemical trends observed are more influenced by fractional 
crystallization processes than crustal contamination effects) to find the optimum fit. R values were tested between 0.2 and 0.8 to allow for a wide envelope. BWA 5, 24, and 25 were used as the initial starting compositions. After several simulations of combining BWA magmas with crustal material, the results produced optimal $\mathrm{r}$ values between 0.2 and 0.5 , indicating that the rate of assimilation of wall rock was moderate during the differentiation of the BWA magmas. These findings support the conclusions made by Bikerman et al. (1990) who ran successful AFC models using measured $\mathrm{Nd}$ and $\mathrm{Sr}$ isotopic data to fit intermediate to mafic volcanic rocks during the 30-20 Ma transition period.

The AFC models fit closely with the FC models showing near identical trends. The similarity between these trend lines likely indicates that the assimilated material is similar in composition with the BWA magmas during transport. However, the amount of fractionation needed to reproduce the data was less. An average of $27 \%$ fractionation was required, with the majority of the BWA samples falling between $10-20 \%$. This is far lower than $30-60 \%$ needed for pure fractional crystallization and is lower than the preferred solution Davis and Hawkesworth (1993) suggested. Therefore, AFC may better explain the petrogenesis of the BWA.

Source Constraints of Bearwallow Mountain Andesite Magmas. Group 1 andesites and group 2 basaltic andesites that make up the BWA are suggested to be co-genetic. The variance between the two groups is likely derived from the amount of differentiation by assimilation and fractional crystallization. This is evident in the change from low $\mathrm{Rb}$ and high $\mathrm{Sr}$ contents in group 2 to higher $\mathrm{Rb}$ and lower $\mathrm{Sr}$ contents in group 1. This inflection point indicates a transitioned to a more plagioclase-stable source. Furthermore, the BWA compositions cluster together when plotted on $\mathrm{Nb}$ versus $\mathrm{La}$ (Fig. 9) as well as having consistent $\mathrm{Zr}$ concentrations, supporting the idea that these two rock groups must have derived from the same source. 
The composition of the magmatic source that produced group 1 and 2 changed over time, adding to the complexities of 30-20 Ma volcanic activity. Combining previously analyzed 30-20 Ma rocks with the newly collected BWA samples, the trends appear to be consistent and extend on a similar path indicative of a common evolving source. The trace-element composition of the BWA establishes a relatively strong calc-alklaine signature indicated by the $\mathrm{Nb}-\mathrm{Ta}$ and $\mathrm{Ti}$ anomalies and enrichment of LREE versus HREE. This supports that BWA magmas have more of a subduction-related origin. Such findings are consistent with those of Davis and Hawkesworth (1993) and McMillan (1998). Therefore, the majority of the BWA was sourced from a subduction-modified lithosphere component, with stronger subduction signatures in older volcanic rocks (e.g. near $30 \mathrm{Ma}$ ). Concluding that this subduction modifying event derived from the flat slab subduction of the Farallon plate is still up for debate, as it may have come from an earlier subduction event (Davis and Hawkesworth, 1995). Davis et al. (1993) suggested that the enrichment of the lithospheric mantle likely occurred long ago during the Proterozoic assembly of the continent. Coupling this data with previously collected isotopic data, elevated ${ }^{87} \mathrm{Sr} /{ }^{86} \mathrm{Sr}$ $(>0.706)$ and low ${ }^{143} \mathrm{Nd} /{ }^{144} \mathrm{Nd}(<0.5125)$ confirm that the BWA was sourced primarily from continental mantle lithosphere rather than upper crustal interactions (Davis, 1991; Davis and Hawkesworth, 1993).

The unusually high $\mathrm{Nb} / \mathrm{Ta}$ ratios $(\sim 19)$ within the BWA magmas may reflect the presence of deep-seated pyroxenite cumulates, known as "arclogites" (Tang et al., 2019). These residual pyroxenites allow the partitioning of $\mathrm{Nb}$ and $\mathrm{Ta}$ in magmatic rutile and Ti-Fe rich phases, and typically form within thick crustal settings, generated during orogenic events. These cumulates, located at the root of continental arcs, removes $\mathrm{Fe}$ and $\mathrm{Nb}$ (relative to $\mathrm{Ta}$ ) from the magmas and drives calc-alkaline differentiation (Tang et al., 2019). This produces the low $\mathrm{Nb} / \mathrm{Ta}$ ratios 
apparent in continental crust (12-13; Tang et al., 2019). However, in the case of the BWA series, rutile-bearing pyroxenites, produced during subduction of the Farallon plate, are likely being melted and incorporated in BWA magmas as a result of decompression melting and upwelling of the asthenosphere during crustal extension. These partial melts would impart "arclogite" signatures into the evolving BWA magmas, giving rise to the unusually high $\mathrm{Nb} / \mathrm{Ta}$ ratios.

Towards the end of this transition period, the magmatic source begins to increase contribution from an OIB-like source. This transition is observed in the change in HFSE contents relative to the LILE and REE contents. The relatively older group 1 andesites (near $30 \mathrm{Ma}$ ), associated with O-Bar-O Mountain, tend to have the lowest HFSE contents. The younger group 2 basaltic andesites associated with the southern Tularosa Mountains, Bearwallow Mountain, and John Kerr Peak, tend to have increasingly higher proportions of the HFSE. Additionally, an increase in $\mathrm{Nb} / \mathrm{La}$ ratios with time, suggest a major shift in magma source closer to the post-20 Ma rocks (Fig. 9). This increase in Nb content is typical of OIB-like composition versus subduction-modified lithospheric mantle (McMillan, 1998). This is also supported by the decrease in $\mathrm{Nb}$ /Ta ratios from abnormally high $(\sim 19)$ to typical OIB values (15-16; Fig. 7a).

Proposed Petrogenetic Model. Magma generation between 30 and 20 Ma was likely the result of a two-stage petrogenetic process involving partial melting of lithospheric mantle, modified from previous subduction, in response to extensional stress rather than roll back of the Farallon plate that fueled earlier eruptions (pre-30 Ma). Assimilation coupled with fractional crystallization proved to be the most successful petrogenetic model that best explained the generation and evolution of BWA magmas. AFC models required the least amount of fractionation (10-20\%) to fit the trace-element trends and indicate that initial stages of BWA magmas were heavily dependent on crustal influences at various depths. The starting basaltic 
composition of the BWA was likely contaminated at considerable depth to produce the initial basaltic liquids for further contamination and differentiation before reaching the Earth's surface (Fig. 10). This is supported by the lack of plagioclase phenocrysts in BWA samples, suggesting differentiation at depths greater than $30 \mathrm{~km}$. The second stage of magma differentiation would involve a basaltic melt with an inherited deep crustal signature from previous contamination, picking up the calc-alkaline affinities from the subduction-modified lithospheric mantle, believed to be from material similar in composition to pre-30 Ma rocks (i.e. Rubio Peak), and inheriting the high $\mathrm{Nb}$ /Ta ratios from melted rutile-bearing pyroxenites. As melting progresses, the magma composition transitions to the more basaltic signatures, characteristic of the andesites and basaltic andesites of the BWA and less of an influence from the older pre-30 Ma rocks. Thus, this early transition period of magma composition after 30 Ma represents the replacement of the deep crustal signature by re-assimilating the magma and hybridizing to a new composition that makes up the majority of the BWA samples.

As intercontinental rifting continues after peak extension at $28.5 \mathrm{Ma}$, decompression melting begins to affect the upper crust permitting increased mobility of the assimilating basaltic magma to ascend to shallower depths (i.e. dike propagation). During this stage, the accumulated magma further differentiates to basaltic andesite to andesite in composition and is likely filtered through a mafic crystal-mush as the magma is being transported towards the surface. This idea of “filtering", postulated by Kent et al. (2010), may explain the reasoning why the BWA magmas were significantly crystal-poor. The filtering effect would ideally remove the majority of the phenocryst phases from the liquid, leaving behind mafic cumulates at various stages during transport, and thus producing a relatively crystal-free rock. These hot, "crystal-free" liquids 
would further ascend to localized pockets to produce slightly variant crustal signatures before erupting at different vent locations within the MDVF.

Proceeding extension near 20 Ma causes the base of the lithosphere to erode and is eventually replaced by the underlying asthenosphere (McMillan, 1998). This allows plumes of upwelling asthenosphere to migrate to shallower depths, enriching the mantle lithosphere. These asthenosphere-derived partial melts likely mixed with later stage 30-20 Ma magmas to produce the observed transition to more OIB-like signatures (i.e. high-Nb magmas). Davis and Hawkesworth (1993) suggested that the younger 30-20 Ma basalts and basaltic andesites were derived from mixing 5-20\% of a high $\mathrm{Nb}$, average post-5 Ma Basin and Range Province alkali basalt with a low $\mathrm{Nb}$ lithosphere derived basalt end-member. However, it should be noted that even the youngest members of the 30-20 Ma group contain only $15-20 \%$ of the asthenopsheric end-member (Davis and Hawkesworth, 1993). Therefore, it is inferred that the lithospheric mantle is what likely controlled the bulk of the mafic to intermediate magma generation between 30-20 Ma and it isn't till after $20 \mathrm{Ma}$ until true theoliitic and alkali basalts form.

\section{Conclusion}

The BWA, making up a large portion of the 30-20 Ma volcanic rocks from the MDVF, are shown to be made up of alkalic to high-K, calc-alkaline lava flows ranging from basalt to andesite in composition. Petrological and geochemical variations within the BWA are shown to be the result of both crustal assimilation and fractionation processes. AFC modelling argues against Davis and Hawkesworth (1993) fractionation model on the grounds that 37\% fractional crystallization is too large to produce the low-silica andesite to basaltic andesites. With such large fractionation, basaltic liquids would likely produce high-silica andesites to near-dacite 
compositions. Therefore, assimilation must be occurring to drive the fractionation percentage down to maintain the andesite to basaltic andesite rock type. Successful AFC models generated BWA basaltic andesites to andesites from parental basaltic magmas with similar compositions to primitive pre-30 Ma rocks using fractionation of a plagioclase + olivine + clionopyroxene +orthopyroxene+magnetite mineral assemblage. The crystal-poor nature of the BWA suggests that the magma was likely compressed and filtered through a basaltic crystal-mush to remove the majority of the phenocryst phases. In addition, the magma likely rapidly ascended to the surface of the Earth through deep conduits as a result of crustal extension. This would reduce the rate of fractionation and the potential of contamination, allowing less evolved basaltic andesite to andesites to erupt.

Mixing models have been successful in previous studies to explain the petrogenesis of 30-20 Ma andesites on the basis of $\mathrm{MgO}$ and $\mathrm{Ni}$ contents, and the presence of olivine phenocrysts (Davis and Hawkesworth, 1993). However, we argue against such findings due to the lack of petrographic evidence (i.e. no disequilibrium textures) as well as the inability to fit trace-element variations. Furthermore, it is difficult to justify mixing of two end-members from significantly different time periods (i.e. post-30 Ma rocks with post-20 Ma rocks). Therefore, magma mixing is not a dominant processes in the production of the andesite to basaltic andesites, but it may play a role in facilitating partial melts of asthenosphere-derived mantle into the continental lithosphere as a minor processes.

Comparison of previously analyzed datasets of pre-30 Ma, 30-20 Ma, and post-20 Ma rocks with experimentally determined AFC trend lines, it is clearly observed that each time period shows a distinct source, showing the progression in magmatism over time with respect to trace-element compositions. The newly added dataset of BWA rocks extends the previously 
established trend of the 30-20 Ma group, indicating that they evolved from the same source. The pre-30 Ma group typically locates near the initial stages of fractionation, with the 30-20 Ma group extending slightly beyond the older rocks, signifying the early transition in magmatic source to the lithospheric mantle. The post-20 Ma group tends to plot as an isolated group, with less overlap of the 30-20 Ma group than the pre-30 Ma group, signifying a different source and increased contributions from an OIB-like end-member. 


\section{References Cited}

Annen, C., Blundy, J.D., and Sparks, R.S.J., 2006, The genesis of intermediate and silicic magmas in deep crustal hot zones: Journal of Petrology, v. 47, no. 3, p. 505-539, doi: 10.1093/petrology/egi084.

Arth, J.G., 1976, Behavior of trace elements during magmatic processes - a summary of theoretical models and their applications: Journal of Research of the U. S. Geological Survey, v. 4, p. 41-47.

Baldridge, W.S., Damon, P.E., Shafiqullah, M., and Bridwell, R.J., 1980, Evolution of the central Rio Grande rift, New Mexico - New potassium-argon ages: Earth and Planetary Science Letters, v. 51, p. 309-321.

Best, M.G., Christiansen, E.H., de Silva, S., and Lipman, P.W., 2016, Slab-rollback ignimbrite flareups in the southern Great Basin and other Cenozoic American arcs: A distinct style of arc volcanism: Geosphere, v. 12, no. 4, p. 1097-1135, doi:10 .1130/GES01285.1.

Bikerman, M., Bell, K., and Card, J.W., 1990, Strontium and neodymium isotopic study of the western Mogollon-Datil volcanic region, New Mexico, USA: Contributions to Mineralogy and Petrology, v. 109, no. 4, p. 459-470, doi:10.1007/bf00306549.

Blundy, J.D., and Wood, B.J., 1991, Crystal-Chemical controls on the partitioning of $\mathrm{Sr}$ and Ba between plagioclase feldspar, silicate melts, and hydrothermal solutions: Geochimica Et Cosmochimica Acta, v. 55, no. 1, p. 193-209.

Bryan, W.B., Finger, L.W., and Chayes, F., 1969, Estimating proportions in petrographic mixing equations by least-squares approximation: Science, v. 163, p. 926-927.

Cather, S.M., 1990, Stress and volcanism in the northern Mogollon-Datil volcanic field, New Mexico: Effects of the post-Laramide tectonic transition: Geological Society of America Bulletin, v. 102, p. 1447-1458.

Chamberlin, R.M., McIntosh, W.C., Eggleston, T.L., 2004, ${ }^{40} \mathrm{Ar} /{ }^{39} \mathrm{Ar}$ geochronology and eruptive history of the eastern sector of the Oligocene Socorro caldera, central Rio Grande rift, New Mexico: New Mexico Bureau of Geology and Mineral Resources, Bulletin, v. 160, p. 251-280.

Chapin, C.E., Seager, R.W., 1975, Evolution of the Rio Grande Rift in the Socorro and Las Cruces areas: New Mexico Geological Society: Guidebook, $26^{\text {th }}$ Field Conference, $p$. 297-321.

Clemons, R.E., ed., 1983, New Mexico highway geologic map: New Mexico Geological Society, $1: 1,000,000$.

Davis, J., 1991, The geochemical evolution of basic and intermediate volcanism of the Mogollon-Datil volcanic field, southwestern New Mexico, USA: PhD thesis, Open University, Milton Keynes, England. 
Davis, J.M., Elston, W.E., and Hawkesworth, C. J., 1993, Basic and intermediate volcanism of the Mogollon-Datil volcanic field: implications for mid-Tertiary tectonic transitions in southwestern New Mexico, USA: Geological Society, London, Special Publications, v. 76, no. 1, p. 469-488, doi:10.1144/gsl.sp.1993.076.01.25.

Davis, J.M., and Hawkesworth, C.J., 1993, The petrogenesis of 30-20 Ma basic and intermediate volcanics from the Mogollon-Datil volcanic field, New Mexico, USA: Contributions to Mineralogy and Petrology, v. 115, no. 2, p. 165-183, doi: 10.1007/BF00321218.

Davis, J.M., and Hawkesworth, C.J., 1994, Early calc-alkaline magmatism in the Mogollon-Datil volcanic field, New Mexico, USA: Journal of the Geological Society, London, v. 151, no. 5, p. 825-843, doi: 10.1144/gsjgs.151.5.0825.

Davis, J.M., and Hawkesworth, C.J., 1995, Geochemical and tectonic transitions in the evolution of the Mogollon-Datil volcanic field, New Mexico, U.S.A: Chemical Geology, v. 119, no. 1-4, p. 31-53, doi:10.1016/0009-2541(94)00094-0.

DePaolo, D.J., 1981, Trace element and isotopic effects of combined wallrock assimilation and fractional crystallization: Earth Planet Science Letters, v. 53, p. 189-202.

Elston, W.E., 1984, Subduction of young oceanic lithosphere and extensional orogeny in southwestern North America during mid-Tertiary time: Tectonics, v. 3, p. 229-250.

Elston, W.E., Damon, P.E., Coney, P.J., Rhodes, R.C., and Bikerman, M., 1973, Tertiary volcanic rocks, Mogollon-Datil province, New Mexico, and surrounding regions: Geological Society of America Bulletin, v. 84, p.2259-2274.

Elston, W.E., Seager, W.R., and Clemons, R.E., 1975, Emory cauldron, Black Range, New Mexico: Source of the Kneeling Nun Tuff: New Mexico Geological Society Guidebook 26, p. 283-292.

Farmer, L.G., Bailley, T., Elkins-Tanton, L.T., 2007, Mantle source volumes and the origin of the mid-Tertiary ignimbrite flare-up in the southern Rocky Mountains, western U.S.: Lithos, v. 102, p. 279-294.

Fujimaki, H., Tatsumoto, M., and Aoki, K., 1984, Partition coefficients of Hf, Zr and REE between phenocrysts and groundmass: Proceedings of the fourteenth lunar and planetary science conference, Part 2: Journal of Geophysical Research, p. 89.

Jarvis, K.E., 1988, Inductively coupled plasma mass spectrometry; a new technique for the rapid or ultra-trace level determination of the rare-earth elements in geological materials: Chemical Geology, v. 68, p. 31-39.

Jicha, H.L., Jr., 1954, Geology and mineral deposits of Lake Valley quadrangle, Grant, Luna, and Sierra Counties, New Mexico: New Mexico Bureau of Mines and Mineral Resources Bulletin, no. 37, p. 93, (incl. geologic map, scale 1:48,000). 
Johnson, D.M., Hooper, P.R., and Conrey, R.M., 1999, XRF analysis of rock and minerals for major and trace elements on a single low dilution Li-tetraborate fused bead: Advances in X-ray analysis, v. 41, p. 843-867.

Kent, A.J.R., Darr, C., Koleszar A.M., et al., 2010, Preferential eruption of andesitic magmas through recharge filtering: Nature Geoscience, v. 3, p. 631-636, doi: 10.1038/ngeo924.

Kent, A. J., 2016, Preferential eruption of andesitic magmas: Implications for volcanic magma fluxes at convergent margins: Geological Society, London, Special Publications, v. 385, no. 1 , p. 257-280, doi:10.1144/sp385.10.

Kuellmer, F.J., 1954, Geologic section of the Black Range at Kingston, New Mexico: New Mexico Bureau of Geology and Mineral Resources, v. 33, p. 100.

Le Bas, M., Le Maitre, R., Streckeisen, A., Zanettin, B., 1986, A chemical classification of volcanic rocks based on the total alkali-silica diagram: Journal of Petrology, v. 27, p. $745-750$.

Lipman, P.W., Prostka, H.J., and Christiansen, R.L., 1972, Cenozoic volcanism and plate tectonic evolution of western United States: Part 1. Early and middle Cenozoic: Philosophical Transactions of the Royal Society of London, v. 271, p. 217-248, doi:10.1098/rsta.1972.0008.

Lipman, P.W., 2007, Incremental assembly and prolonged consolidation of Cordilleran magma chambers: Evidence from the Southern Rocky Mountain volcanic field: Geosphere, v. 3, p. 42-70, doi: $10.1130 /$ GES00061 .1.

MacDonald, G.A., and Katsura T., 1964, Chemical composition of Hawaiian lavas: Journal of Petrology, 5:82-133.

Macpherson, C.G., Dreher, S.T. and Thirlwall, M.F., 2006, Adakites without slab melting: High pressure differentiation of island arc magma, Mindanao, the Philippines: Earth and Planetary Science Letters, v. 243, p. 581-593.

McIntosh, W.C., Chapin, C.E., Ratté, J.C., and Sutter, J.F., 1992, Time-stratigraphic framework for the Eocene-Oligocene Mogollon-Datil volcanic field, southwest New Mexico: Geological Society of America Bulletin, v. 104, no. 7, p. 851-871.

McIntosh, W.C., and Bryan, C., 2000, Chronology and geochemistry of the Boot Heel volcanic field, New Mexico: New Mexico Geological Society, 51st Field Conference Guidebook, p.167-174.

McMillan, N.J., 1998, Temporal and spatial magmatic evolution of the Rio Grande rift, in Mack, G.H., Austin, G.S., and Barker, J.M., eds., Las Cruces Country II: New Mexico Geological Society 49th Annual Fall Field Conference Guidebook, p. 107-116. 
McMillan, N.J., Dickin, A.P., and Haag, D., 2000, Evolution of magma source regions in the Rio Grande rift, southern New Mexico: Geological Society of America Bulletin, v. 112, p. 1582-1593.

Miyashiro, A., 1974, Volcanic rock series in island arcs and active continental margins: American Journal of Science, v. 274, p. 321-355.

Nieto-Samaniego, A.N.F., Ferrari, L., Alaniz-Alvarez, S.A., Labarthe-Hernández, G., and RosasElguera, J., 1999, Variation of Cenozoic extension and volcanism across the southern Sierra Madre Occidental volcanic province, Mexico: GSA Bulletin, v. 111, no. 3, p. 347363.

Oehring, B., Michelfelder, G.S., 2017, Intermediate volcanic rocks of the western MogollonDatil volcanic field, southern New Mexico: A change in magmatic source after ignimbrite flare-up: Geological Society of America Abstracts with Programs. v. 49, no. 6, doi: 10.1130/abs/2017AM-306916.

Tang, M., Lee, C.A., Chen, K., Erdman, M., Costin, G., and Jiang, H., 2019, Nb/Ta systematics in arc magma differentiation and the role of arclogites in continent formation: Nature Communications, v. 10, no. 1, doi:10.1038/s41467-018-08198-3.

Parlak, O., 2006, Geodynamic significance of granitoid magmatism in the southeast Anatolian orogen: geochemical and geochronogical evidence from Göksun-Afşin (Kahramanmaraş, Turkey) region: International Journal of Earth Sciences, v. 95, p. 605-627.

Peacock, M.A., 1931, Classification of igneous rocks: The Journal of Geology, v. 39, p. 54-67.

Pearce, J.A., 1982, Trace Element Characteristics of Lavas from Destructive Plate Boundaries, in Thorpe, R.S., ed., Andesites: Orogenic Andesites and Related Rocks, John Wiley and Sons, p. 252-548.

Pearce, J.A. and Cann, J.R., 1973, Tectonic setting of basic volcanic rocks determined using trace element analyses: Earth and Planetary Science Letters, v. 19, p. 290-300.

Perugini, D., and Poli, G., 2012, The mixing of magmas in plutonic and volcanic environments: Analogies and differences: Lithos, v. 153, p. 261-277, doi:10.1016/j.lithos.2012.02.002.

Ratté, J.C., Marvin, R.F., and Naeser, C.W., 1984, Calderas and ash flow tuffs of the Mogollon Mountains, southwestern New Mexico: Journal of Geophysical Research, v. 89, no. B10, p. 8713-8732, doi: 10.1029/JB089iB10p08713.

Rollinson, H.R., 1993, Using geochemical data: Evaluation, presentation, interpretation. Abingdon: Routledge.

Schneider, R.V., and Keller, G.R., 1994, Crustal structure of the western margin of the Rio Grande rift and Mogollon-Datil volcanic field, southwestern New Mexico and southeastern Arizona, in Keller G.R., and Cather S.M., eds., Basins of the Rio Grande 
Rift: Structure, Stratigraphy, and Tectonic Setting: Boulder, Colorado, Geological Society of America Special Paper 291, p. 207-226.

Sisson, T.W., Grove TL, 1993, Temperatures and $\mathrm{H}_{2} 0$ contents of low-MgO high-alumina basalts: Contributions to Mineralogy and Petrology, v. 113, p.167-184.

Straub, S.M., Gómez-Tuena, A., Bindeman, I.N., Bolge, L.L., Brandl, P.A., Espinasa-Pereña, R., ... Zellmer, G. F., 2015, Corrigendum to "Crustal recycling by subduction erosion in the central Mexican Volcanic Belt" [Geochim. Cosmochim. Acta 166, 2015, p. 29-52]: Geochimica Et Cosmochimica Acta, 171, p. 374-375, doi:10.1016/j.gca.2015.09.028.

Sun and McDonough, 1989, Chemical and isotopic systematics of oceanic basalts: implication for mantle composition and processes, in Saunder, A.D., Norry, M.J., (Eds.), Magmatism in the ocean basins: Geological Society, London, Special Publications, v. 42, p. 313-345.

Tonking, W.H., 1957, Geology of Puertecito quadrangle, Socorro County, New Mexico: New Mexico Institute of Mining and Technology, State Bureau of Mines and Mineral Resources, Bull. 42.

Weaver, B. and Tarney J., 1984, Empirical approach to estimating the composition of the continental crust: Nature, v. 310, p. 575-57. 
Table 1. Major- and trace-element compositions of the BWA measured by XRF.

\begin{tabular}{|c|c|c|c|c|c|c|}
\hline $\begin{array}{l}\text { Sample } \\
\text { Locality }\end{array}$ & $\begin{array}{l}\text { BWA-02 } \\
\text { Willow Springs } \\
\text { Canyon }\end{array}$ & $\begin{array}{l}\text { BWA-05 } \\
\text { Telephone } \\
\text { Canyon }\end{array}$ & $\begin{array}{l}\text { BWA-12 } \\
\text { O-Bar-O } \\
\text { Mtn }\end{array}$ & $\begin{array}{l}\text { BWA-13 } \\
\text { O-Bar-O } \\
\text { Mtn }\end{array}$ & $\begin{array}{l}\text { BWA-14 } \\
\text { O-Bar-O } \\
\text { Mtn }\end{array}$ & $\begin{array}{l}\text { BWA-15 } \\
\text { O-Bar-O } \\
\text { Mtn }\end{array}$ \\
\hline Latitude & 33.571 & 33.546 & 33.603 & 33.608 & 33.608 & 33.607 \\
\hline Longitude & -108.727 & -108.615 & -108.320 & -108.322 & -108.321 & -108.320 \\
\hline $\mathrm{SiO}_{2}$ & 57.84 & 61.23 & 55.69 & 59.74 & 60.01 & 58.49 \\
\hline $\mathrm{TiO}_{2}$ & 1.36 & 0.74 & 1.26 & 1.02 & 1.02 & 1.01 \\
\hline $\mathrm{Al}_{2} \mathrm{O}_{3}$ & 15.79 & 16.34 & 17.03 & 16.05 & 16.09 & 16.19 \\
\hline $\mathrm{FeO}^{*}$ & 7.32 & 5.05 & 7.60 & 6.25 & 6.21 & 6.15 \\
\hline $\mathrm{MnO}$ & 0.11 & 0.07 & 0.12 & 0.10 & 0.10 & 0.10 \\
\hline $\mathrm{MgO}$ & 3.12 & 2.02 & 3.14 & 2.92 & 2.86 & 3.04 \\
\hline $\mathrm{CaO}$ & 5.46 & 5.01 & 5.78 & 5.45 & 5.44 & 5.58 \\
\hline $\mathrm{Na}_{2} \mathrm{O}$ & 3.85 & 3.94 & 3.24 & 3.37 & 3.51 & 3.25 \\
\hline $\mathrm{K}_{2} \mathrm{O}$ & 3.03 & 2.71 & 2.28 & 2.96 & 2.96 & 3.02 \\
\hline $\mathrm{P}_{2} \mathrm{O}_{5}$ & 0.70 & 0.19 & 0.71 & 0.41 & 0.43 & 0.44 \\
\hline Sum & 98.59 & 97.30 & 96.85 & 98.27 & 98.64 & 97.26 \\
\hline LOI \% & 0.48 & 1.88 & 2.13 & 1.06 & 0.78 & 1.86 \\
\hline Mg\# & 43.20 & 41.70 & 42.40 & 45.40 & 45.10 & 46.80 \\
\hline $\mathrm{Ni}$ & 44.12 & 25.96 & 67.17 & 44.92 & 44.04 & 40.80 \\
\hline $\mathrm{Cr}$ & 66.73 & 37.88 & 98.88 & 63.52 & 62.62 & 69.00 \\
\hline $\mathrm{Sc}$ & 14.17 & 10.91 & 17.78 & 14.07 & 14.34 & 12.60 \\
\hline $\mathrm{V}$ & 125.6 & 108.0 & 119.2 & 116.0 & 116.4 & 114.8 \\
\hline $\mathrm{Ba}$ & 1341 & 850 & 1428 & 1149 & 1152 & 1166 \\
\hline $\mathrm{Rb}$ & 72.40 & 73.16 & 39.11 & 80.18 & 75.93 & 72.72 \\
\hline $\mathrm{Sr}$ & 733.2 & 519.5 & 632.7 & 583.5 & 583.3 & 579.0 \\
\hline $\mathrm{Zr}$ & 352.0 & 198.8 & 340.7 & 313.9 & 314.9 & 306.1 \\
\hline $\mathrm{Y}$ & 35.18 & 19.29 & 36.46 & 35.48 & 38.28 & 34.40 \\
\hline $\mathrm{Nb}$ & 18.19 & 6.97 & 14.34 & 13.17 & 13.53 & 12.80 \\
\hline $\mathrm{Ga}$ & 19.80 & 17.68 & 21.31 & 19.40 & 19.90 & 19.30 \\
\hline $\mathrm{Cu}$ & 32.96 & 35.86 & 44.54 & 39.30 & 39.79 & 40.20 \\
\hline $\mathrm{Zn}$ & 99.09 & 68.58 & 97.06 & 83.11 & 84.64 & 83.10 \\
\hline $\mathrm{Pb}$ & 14.67 & 12.63 & 14.85 & 15.18 & 13.84 & 15.40 \\
\hline $\mathrm{La}$ & 62.41 & 29.29 & 55.85 & 50.75 & 52.32 & 53.60 \\
\hline $\mathrm{Ce}$ & 133.1 & 60.70 & 117.6 & 109.1 & 112.0 & 112.5 \\
\hline $\mathrm{Th}$ & 8.14 & 7.17 & 8.38 & 9.45 & 8.59 & 9.80 \\
\hline $\mathrm{Nd}$ & 56.78 & 26.97 & 55.55 & 48.14 & 50.30 & 50.70 \\
\hline $\mathrm{U}$ & 2.11 & 2.12 & 3.03 & 3.32 & 0.71 & 2.60 \\
\hline
\end{tabular}


Table 1 (continued). Major- and trace-element compositions of the BWA measured by XRF.

\begin{tabular}{|c|c|c|c|c|c|c|}
\hline BWA-16 & BWA-17 & BWA-18 & BWA-19 & BWA-20 & BWA-21 & BWA-22 \\
\hline O-Bar-O & O-Bar-O & Telephone & Telephone & Telephone & Telephone & Telephone \\
\hline Mtn & Mtn & Canyon & Canyon & Canyon & Canyon & Canyon \\
\hline 33.606 & 33.605 & 33.531 & 33.531 & 33.531 & 33.531 & 33.530 \\
\hline-108.320 & -108.320 & -108.583 & -108.583 & -108.583 & -108.584 & -108.584 \\
\hline 59.59 & 59.47 & 56.51 & 56.10 & 56.15 & 54.04 & 52.09 \\
\hline 1.01 & 1.00 & 1.27 & 1.27 & 1.31 & 1.49 & 1.81 \\
\hline 15.89 & 15.84 & 16.21 & 16.06 & 16.41 & 16.26 & 16.18 \\
\hline 6.26 & 6.16 & 7.29 & 7.28 & 7.47 & 8.21 & 9.89 \\
\hline 0.10 & 0.10 & 0.11 & 0.12 & 0.12 & 0.12 & 0.15 \\
\hline 2.56 & 3.02 & 3.91 & 3.42 & 3.88 & 4.34 & 4.74 \\
\hline 5.37 & 5.41 & 5.89 & 5.73 & 6.09 & 6.57 & 7.38 \\
\hline 3.72 & 3.42 & 3.54 & 3.69 & 3.55 & 3.59 & 3.35 \\
\hline 2.99 & 3.00 & 2.89 & 3.04 & 2.73 & 2.57 & 1.93 \\
\hline 0.40 & 0.40 & 0.50 & 0.51 & 0.54 & 0.64 & 0.56 \\
\hline 97.89 & 97.82 & 98.14 & 97.21 & 98.24 & 97.83 & 98.07 \\
\hline 1.27 & 1.20 & 0.93 & 1.82 & 1.17 & 1.34 & 1.42 \\
\hline 42.20 & 46.70 & 48.80 & 45.60 & 48.10 & 48.50 & 46.10 \\
\hline 45.10 & 43.70 & 73.70 & 74.00 & 74.37 & 103.70 & 80.90 \\
\hline 62.50 & 73.90 & 110.1 & 108.1 & 113.7 & 148.9 & 137.3 \\
\hline 13.60 & 14.90 & 15.80 & 15.00 & 16.38 & 17.70 & 20.60 \\
\hline 117.1 & 115.9 & 129.6 & 139.3 & 140.9 & 156.9 & 173.1 \\
\hline 1125 & 1175 & 1166 & 1157 & 1210 & 1183 & 857 \\
\hline 84.77 & 80.95 & 64.97 & 72.13 & 59.40 & 55.27 & 39.50 \\
\hline 569.5 & 576.2 & 671.8 & 647.4 & 692.4 & 735.3 & 651.2 \\
\hline 310.9 & 307.6 & 291.3 & 290.9 & 297.6 & 276.9 & 276.3 \\
\hline 42.30 & 34.80 & 31.70 & 33.70 & 33.06 & 31.60 & 38.78 \\
\hline 12.80 & 12.40 & 15.10 & 14.80 & 15.28 & 17.00 & 19.29 \\
\hline 19.90 & 19.90 & 18.90 & 19.00 & 19.10 & 19.40 & 19.70 \\
\hline 38.20 & 39.50 & 45.00 & 40.20 & 42.91 & 49.00 & 35.86 \\
\hline 82.00 & 80.90 & 89.00 & 94.60 & 91.05 & 96.00 & 102.0 \\
\hline 14.30 & 14.70 & 13.00 & 13.10 & 12.36 & 11.60 & 8.89 \\
\hline 55.80 & 48.50 & 49.90 & 52.50 & 52.56 & 48.00 & 45.45 \\
\hline 108.6 & 109.8 & 99.00 & 99.90 & 106.1 & 107.5 & 90.60 \\
\hline 8.80 & 10.20 & 7.50 & 6.10 & 7.34 & 6.50 & 3.84 \\
\hline 48.60 & 48.20 & 47.20 & 47.90 & 47.74 & 50.00 & 45.85 \\
\hline 1.70 & 1.10 & 2.70 & 1.50 & 1.71 & 2.30 & 3.33 \\
\hline
\end{tabular}


Table 1 (continued). Major- and trace-element compositions of the BWA measured by XRF.

\begin{tabular}{|c|c|c|c|c|c|c|}
\hline $\begin{array}{l}\text { BWA-23 } \\
\text { Telephone } \\
\text { Canyon }\end{array}$ & $\begin{array}{l}\text { BWA-24 } \\
\text { Telephone } \\
\text { Canyon }\end{array}$ & $\begin{array}{l}\text { BWA-25 } \\
\text { Telephone } \\
\text { Canyon }\end{array}$ & $\begin{array}{l}\text { BWA-26 } \\
\text { John Kerr } \\
\text { Peak }\end{array}$ & $\begin{array}{l}\text { BWA-28 } \\
\text { John Kerr } \\
\text { Peak }\end{array}$ & $\begin{array}{l}\text { BWA-29 } \\
\text { John Kerr } \\
\text { Peak }\end{array}$ & $\begin{array}{l}\text { BWA-30 } \\
\text { Francisco } \\
\text { Mountains }\end{array}$ \\
\hline 33.530 & 33.530 & 33.530 & 33.749 & 33.762 & 33.774 & 33.780 \\
\hline-108.585 & -108.585 & -108.584 & -108.481 & -108.460 & -108.449 & -108.932 \\
\hline 52.22 & 51.81 & 51.33 & 55.03 & 54.59 & 51.92 & 47.17 \\
\hline 1.88 & 1.26 & 1.38 & 1.54 & 1.52 & 1.96 & 1.71 \\
\hline 16.14 & 16.00 & 17.67 & 16.51 & 16.32 & 15.69 & 17.80 \\
\hline 9.66 & 9.27 & 9.82 & 8.70 & 8.33 & 10.16 & 10.29 \\
\hline 0.14 & 0.15 & 0.17 & 0.13 & 0.13 & 0.15 & 0.16 \\
\hline 4.59 & 4.53 & 2.33 & 3.15 & 3.28 & 3.83 & 6.73 \\
\hline 7.29 & 7.90 & 7.19 & 6.42 & 6.40 & 7.06 & 9.97 \\
\hline 3.51 & 3.23 & 3.35 & 3.90 & 3.71 & 3.54 & 3.18 \\
\hline 1.96 & 2.31 & 2.77 & 2.68 & 2.67 & 2.21 & 0.73 \\
\hline 0.57 & 0.49 & 0.54 & 0.82 & 0.81 & 1.32 & 0.26 \\
\hline 97.96 & 96.95 & 96.55 & 98.88 & 97.77 & 97.84 & 98.01 \\
\hline 1.40 & 2.17 & 2.88 & 0.55 & 1.44 & 1.59 & 1.58 \\
\hline 45.80 & 46.60 & 29.80 & 39.20 & 41.30 & 40.20 & 53.80 \\
\hline 74.57 & 100.8 & 108.5 & 54.77 & 55.20 & 46.73 & 87.64 \\
\hline 132.2 & 198.2 & 188.2 & 82.1 & 79.80 & 60.20 & 113.5 \\
\hline 20.70 & 22.61 & 23.53 & 18.79 & 16.30 & 17.99 & 24.42 \\
\hline 184.5 & 187.6 & 170.0 & 165.8 & 154.7 & 180.1 & 213.4 \\
\hline 809 & 810 & 939 & 1283 & 1287 & 1322 & 287 \\
\hline 34.08 & 48.56 & 49.90 & 63.93 & 50.47 & 53.58 & 14.97 \\
\hline 625.4 & 624.8 & 676.7 & 745.0 & 742.6 & 878.2 & 547.4 \\
\hline 280.1 & 206.9 & 226.2 & 347.6 & 339.6 & 324.2 & 118.0 \\
\hline 37.59 & 31.86 & 32.42 & 40.90 & 38.60 & 40.60 & 20.60 \\
\hline 19.80 & 10.55 & 12.22 & 19.20 & 18.90 & 20.60 & 22.61 \\
\hline 18.49 & 18.39 & 19.59 & 19.40 & 19.20 & 19.30 & 16.78 \\
\hline 37.79 & 55.38 & 66.76 & 45.02 & 43.20 & 39.80 & 51.56 \\
\hline 101.3 & 90.85 & 91.00 & 109.6 & 103.1 & 122.0 & 79.70 \\
\hline 8.24 & 9.65 & 10.71 & 10.85 & 11.00 & 10.15 & 1.61 \\
\hline 40.90 & 38.79 & 39.90 & 61.41 & 59.50 & 63.11 & 20.10 \\
\hline 82.71 & 76.08 & 86.56 & 126.8 & 127.9 & 132.7 & 37.08 \\
\hline 5.13 & 6.93 & 5.66 & 7.54 & 6.10 & 4.62 & 2.81 \\
\hline 46.73 & 36.98 & 43.43 & 56.88 & 60.00 & 65.02 & 18.69 \\
\hline 2.51 & 1.71 & 2.53 & 2.31 & 3.00 & 2.41 & 1.41 \\
\hline
\end{tabular}


Table 2. Trace-element compositions of the BWA measured by ICP-MS.

\begin{tabular}{|c|c|c|c|c|c|c|c|}
\hline Sample & BWA-02 & BWA-05 & BWA-12 & BWA-13 & BWA-14 & BWA-15 & BWA-16 \\
\hline $\mathrm{La}$ & 64.97 & 28.97 & 59.06 & 53.76 & 57.62 & 55.83 & 56.03 \\
\hline $\mathrm{Ce}$ & 132.5 & 59.88 & 119.8 & 109.5 & 111.1 & 109.5 & 108.8 \\
\hline $\operatorname{Pr}$ & 15.66 & 7.01 & 14.73 & 12.95 & 13.23 & 13.40 & 13.17 \\
\hline $\mathrm{Nd}$ & 60.15 & 27.40 & 56.68 & 49.39 & 51.57 & 51.15 & 50.53 \\
\hline $\mathrm{Sm}$ & 11.38 & 5.34 & 10.87 & 9.46 & 9.91 & 9.85 & 9.85 \\
\hline $\mathrm{Eu}$ & 2.77 & 1.34 & 2.56 & 2.17 & 2.25 & 2.25 & 2.23 \\
\hline Gd & 9.12 & 4.46 & 9.05 & 8.13 & 8.38 & 8.20 & 8.38 \\
\hline $\mathrm{Tb}$ & 1.35 & 0.67 & 1.37 & 1.27 & 1.29 & 1.26 & 1.31 \\
\hline Dy & 7.59 & 3.90 & 7.73 & 7.10 & 7.49 & 7.26 & 7.62 \\
\hline Ho & 1.47 & 0.76 & 1.48 & 1.39 & 1.48 & 1.40 & 1.53 \\
\hline $\mathrm{Er}$ & 3.70 & 1.97 & 3.81 & 3.70 & 3.87 & 3.65 & 4.15 \\
\hline $\mathrm{Tm}$ & 0.53 & 0.28 & 0.54 & 0.52 & 0.56 & 0.52 & 0.57 \\
\hline $\mathrm{Yb}$ & 3.12 & 1.74 & 3.29 & 3.16 & 3.34 & 3.08 & 3.47 \\
\hline $\mathrm{Lu}$ & 0.49 & 0.27 & 0.49 & 0.49 & 0.52 & 0.47 & 0.55 \\
\hline $\mathrm{Ba}$ & 1358 & 860.0 & 1438 & 1170 & 1157 & 1184 & 1144 \\
\hline Th & 7.47 & 7.03 & 8.44 & 8.84 & 8.91 & 8.97 & 8.89 \\
\hline $\mathrm{Nb}$ & 17.78 & 7.00 & 14.56 & 13.36 & 13.25 & 13.29 & 12.95 \\
\hline $\mathrm{Y}$ & 37.57 & 19.33 & 38.27 & 36.51 & 39.87 & 36.30 & 42.80 \\
\hline $\mathrm{Hf}$ & 8.41 & 5.33 & 8.31 & 7.79 & 7.77 & 7.85 & 7.68 \\
\hline $\mathrm{Ta}$ & 0.97 & 0.47 & 0.82 & 0.78 & 0.77 & 0.77 & 0.78 \\
\hline $\mathrm{U}$ & 1.26 & 1.71 & 1.42 & 1.56 & 1.57 & 1.50 & 1.58 \\
\hline $\mathrm{Pb}$ & 14.95 & 12.82 & 15.36 & 14.49 & 14.13 & 14.70 & 13.45 \\
\hline $\mathrm{Rb}$ & 71.54 & 72.60 & 37.94 & 78.89 & 77.11 & 74.10 & 84.04 \\
\hline $\mathrm{Cs}$ & 0.76 & 1.78 & 0.61 & 0.98 & 0.80 & 0.85 & 0.57 \\
\hline $\mathrm{Sr}$ & 738.0 & 514.2 & 638.3 & 582.9 & 581.4 & 595.6 & 566.1 \\
\hline $\mathrm{Sc}$ & 14.75 & 10.60 & 17.43 & 14.59 & 14.31 & 14.54 & 14.31 \\
\hline $\mathrm{Zr}$ & 356.8 & 198.2 & 347.7 & 318.4 & 316.5 & 321.4 & 313.7 \\
\hline
\end{tabular}


Table 2 (continued). Trace-element compositions of the BWA measured by ICP-MS.

\begin{tabular}{|c|c|c|c|c|c|c|c|}
\hline BWA-17 & BWA-18 & BWA-19 & BWA-20 & BWA-21 & BWA-22 & BWA-23 & BWA-24 \\
\hline 54.29 & 52.12 & 53.24 & 52.66 & 52.08 & 42.88 & 42.16 & 37.15 \\
\hline 108.6 & 104.3 & 106.9 & 106.4 & 103.6 & 87.47 & 86.95 & 75.37 \\
\hline 13.19 & 12.53 & 12.80 & 12.71 & 12.64 & 11.38 & 11.42 & 9.58 \\
\hline 49.86 & 47.84 & 49.76 & 48.49 & 49.17 & 46.47 & 46.38 & 38.42 \\
\hline 9.64 & 9.20 & 9.44 & 9.40 & 9.45 & 9.52 & 9.92 & 7.80 \\
\hline 2.18 & 2.31 & 2.36 & 2.32 & 2.43 & 2.64 & 2.62 & 2.09 \\
\hline 7.99 & 7.68 & 7.88 & 7.81 & 7.82 & 8.67 & 8.78 & 6.85 \\
\hline 1.23 & 1.17 & 1.19 & 1.17 & 1.17 & 1.33 & 1.35 & 1.04 \\
\hline 7.13 & 6.55 & 6.84 & 6.69 & 6.59 & 7.73 & 7.94 & 6.22 \\
\hline 1.36 & 1.28 & 1.32 & 1.29 & 1.27 & 1.53 & 1.57 & 1.23 \\
\hline 3.68 & 3.37 & 3.47 & 3.34 & 3.28 & 4.00 & 4.17 & 3.23 \\
\hline 0.51 & 0.48 & 0.48 & 0.48 & 0.45 & 0.57 & 0.57 & 0.47 \\
\hline 3.14 & 2.87 & 2.96 & 2.87 & 2.77 & 3.46 & 3.41 & 2.73 \\
\hline 0.49 & 0.43 & 0.45 & 0.44 & 0.42 & 0.52 & 0.53 & 0.45 \\
\hline 1194 & 1182 & 1174 & 1209 & 1188 & 859.9 & 815.0 & 821.1 \\
\hline 8.86 & 7.09 & 7.13 & 7.05 & 6.17 & 3.90 & 3.98 & 5.59 \\
\hline 13.07 & 14.96 & 14.91 & 15.17 & 17.20 & 18.60 & 19.64 & 11.02 \\
\hline 35.71 & 33.20 & 33.93 & 33.55 & 32.97 & 39.62 & 39.69 & 31.60 \\
\hline 7.71 & 7.25 & 7.22 & 7.25 & 6.82 & 6.58 & 6.79 & 5.26 \\
\hline 0.75 & 0.84 & 0.84 & 0.86 & 0.96 & 1.08 & 1.16 & 0.62 \\
\hline 1.54 & 1.16 & 1.23 & 1.15 & 1.07 & 0.85 & 0.86 & 1.19 \\
\hline 14.89 & 13.07 & 13.05 & 12.57 & 12.04 & 8.12 & 8.02 & 9.75 \\
\hline 82.40 & 64.98 & 72.14 & 58.21 & 54.22 & 37.33 & 33.09 & 48.01 \\
\hline 0.99 & 0.66 & 0.88 & 0.52 & 0.48 & 0.44 & 0.21 & 0.60 \\
\hline 586.2 & 681.2 & 651.3 & 689.0 & 748.3 & 650.4 & 640.2 & 629.5 \\
\hline 14.22 & 15.32 & 15.17 & 15.86 & 17.23 & 20.38 & 20.88 & 23.51 \\
\hline 316.0 & 297.6 & 295.6 & 302.0 & 286.0 & 276.5 & 289.7 & 209.7 \\
\hline
\end{tabular}


Table 2 (continued). Trace-element compositions of the BWA measured by ICP-MS.

\begin{tabular}{|c|c|c|c|c|}
\hline BWA-25 & BWA-26 & BWA-28 & BWA-29 & BWA-30 \\
\hline 40.93 & 63.09 & 61.61 & 65.74 & 17.61 \\
\hline 83.95 & 129.9 & 128.7 & 139.5 & 35.94 \\
\hline 10.65 & 15.83 & 15.79 & 17.37 & 4.48 \\
\hline 42.59 & 62.49 & 61.60 & 69.70 & 18.55 \\
\hline 8.62 & 12.09 & 11.87 & 13.47 & 4.43 \\
\hline 2.28 & 3.14 & 3.11 & 3.78 & 1.56 \\
\hline 7.60 & 9.92 & 9.75 & 11.00 & 4.30 \\
\hline 1.14 & 1.48 & 1.45 & 1.60 & 0.70 \\
\hline 6.73 & 8.31 & 8.02 & 8.92 & 4.16 \\
\hline 1.33 & 1.59 & 1.57 & 1.67 & 0.79 \\
\hline 3.52 & 4.10 & 3.97 & 4.19 & 2.09 \\
\hline 0.49 & 0.58 & 0.55 & 0.56 & 0.29 \\
\hline 2.95 & 3.41 & 3.28 & 3.29 & 1.77 \\
\hline 0.46 & 0.54 & 0.51 & 0.51 & 0.27 \\
\hline 939.4 & 1284 & 1305 & 1334 & 281.3 \\
\hline 6.19 & 5.74 & 5.73 & 4.07 & 2.22 \\
\hline 12.34 & 18.86 & 18.67 & 20.36 & 21.83 \\
\hline 33.59 & 41.89 & 39.81 & 42.23 & 19.92 \\
\hline 5.86 & 8.21 & 8.11 & 7.53 & 2.82 \\
\hline 0.68 & 1.04 & 1.02 & 1.08 & 1.38 \\
\hline 1.29 & 1.01 & 1.08 & 0.86 & 0.62 \\
\hline 10.87 & 11.66 & 11.57 & 10.44 & 1.55 \\
\hline 50.07 & 62.85 & 50.14 & 50.77 & 13.60 \\
\hline 0.78 & 0.61 & 0.43 & 0.42 & 0.17 \\
\hline 700.5 & 750.5 & 756.5 & 889.8 & 550.8 \\
\hline 25.52 & 17.37 & 17.06 & 19.00 & 24.40 \\
\hline 232.9 & 351.2 & 345.6 & 334.1 & 115.6 \\
\hline
\end{tabular}




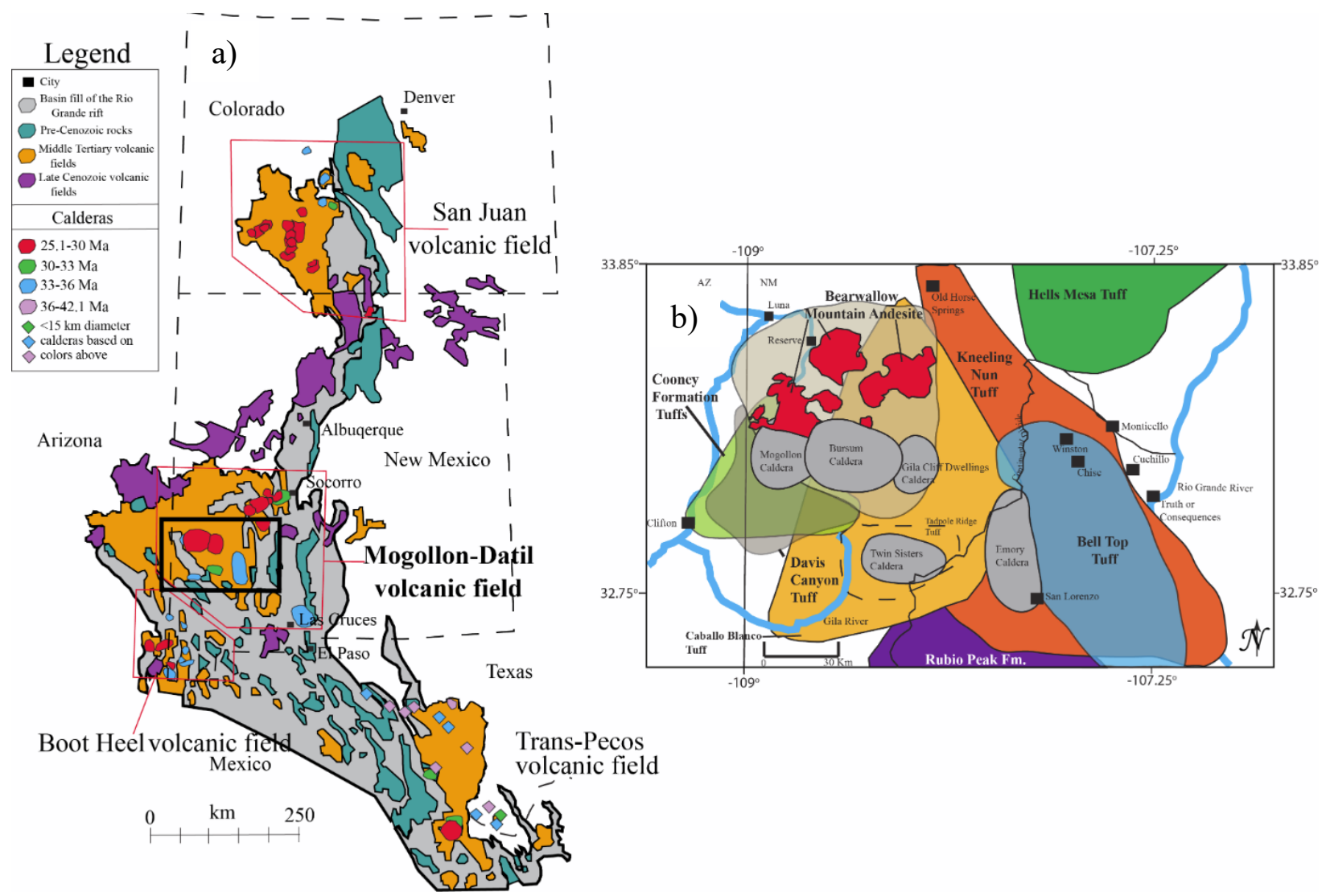

Figure 1. a) Regional map of the Mogollon-Datil volcanic field (MDVF) and Rio Grande rift volcanic area and b) north-central extent of the MDVF outlining caldera locations, major ignimbrite ash-flow tuffs, and the Bearwallow Mountain Andesite lava flows. 

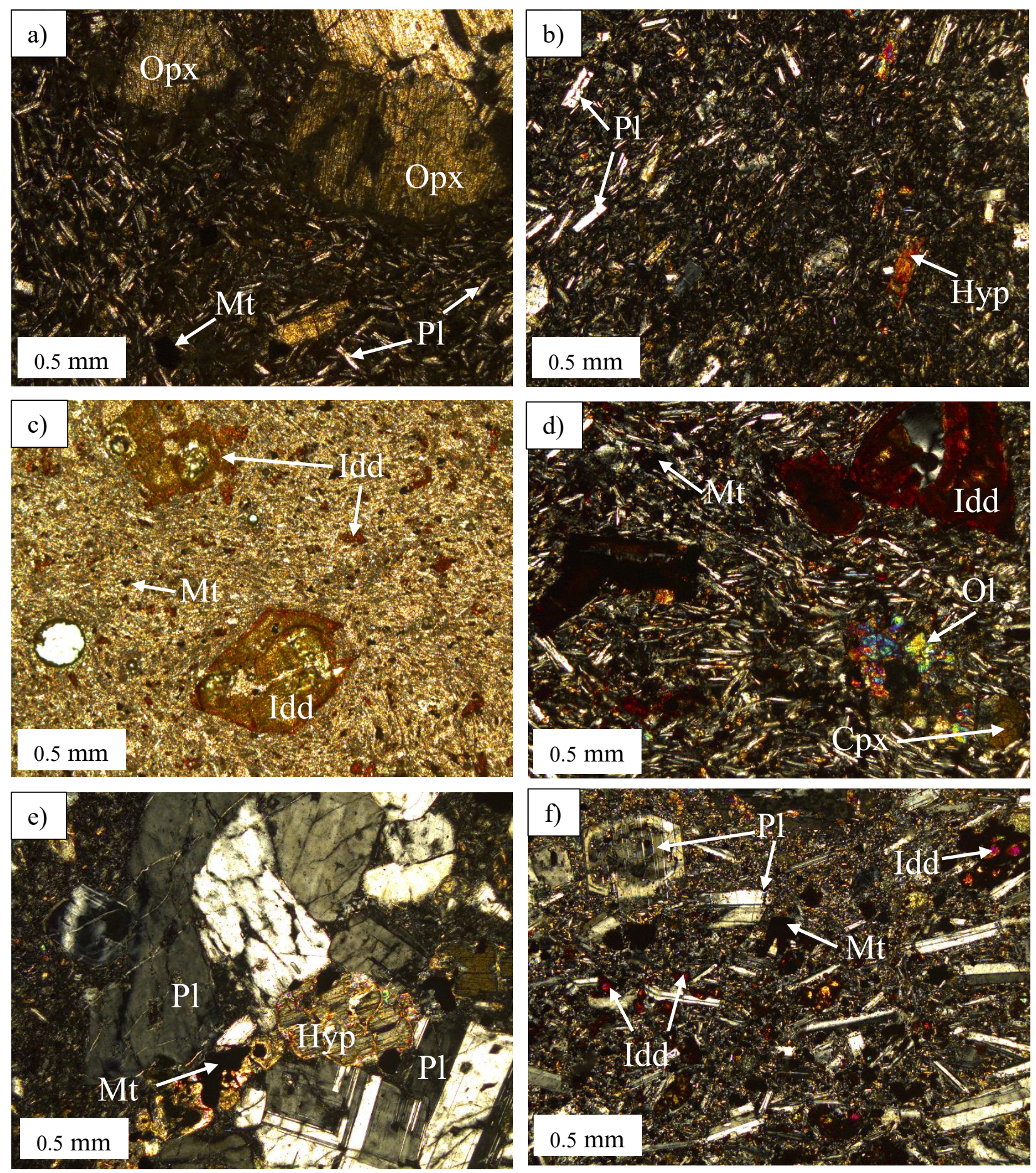

Figure 2. Photomicrographs of the Bearwallow Mountain Andesite. a) Andesite from Pelona Peak (XPL); b) Andesite from O-Bar-O Mountain (XPL); c) Basaltic andesite from Telephone Canyon (PPL); d) Basaltic Andesite from John Kerr Peak (XPL); e) Andesite from Telephone Canyon, likely from the Bear Springs Formation (BWA 5; XPL); f) Basalt from northern area of the Francisco Mountains (BWA 30; XPL). Pl: plagioclase; Opx: orthopyroxene; Cpx: clinopyroxene; Hyp: hypersthene; Ol: olivine; Idd: iddingsite; Mt: magnetite. 


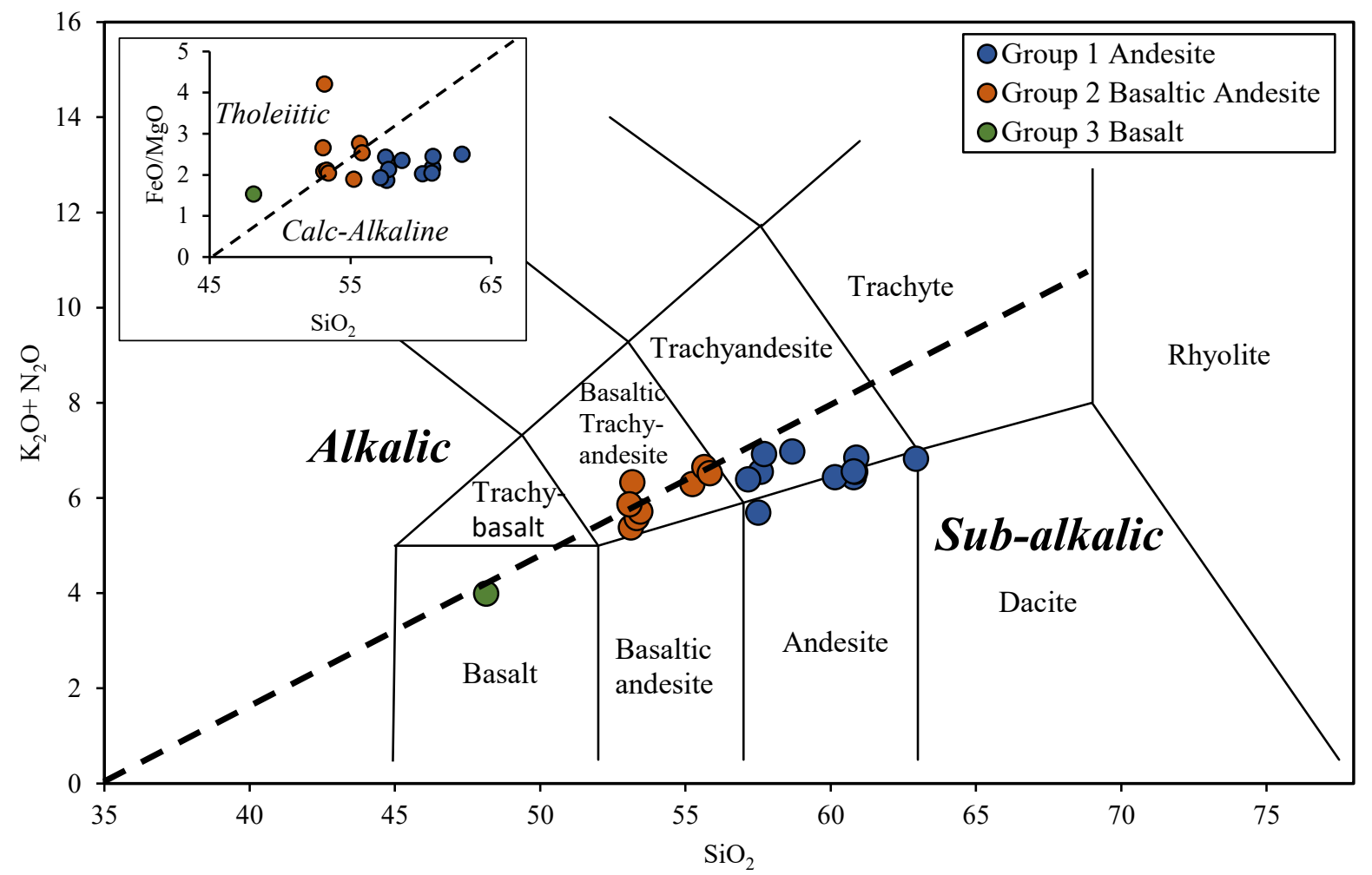

Figure 3. Total alkali vs. silica diagram for the BWA series, using the IUGS classification defined by Le Bas et al. (1986). Also shown is the alkali/subalkalic division of MacDonald and Katsura (1964). The inset diagram shows the BWA series plotted on $\mathrm{FeO}$ (Fe total)/MgO vs. $\mathrm{SiO}_{2}$, with the tholeiitic-calcalkaline boundary taken from Miyashiro (1974). 

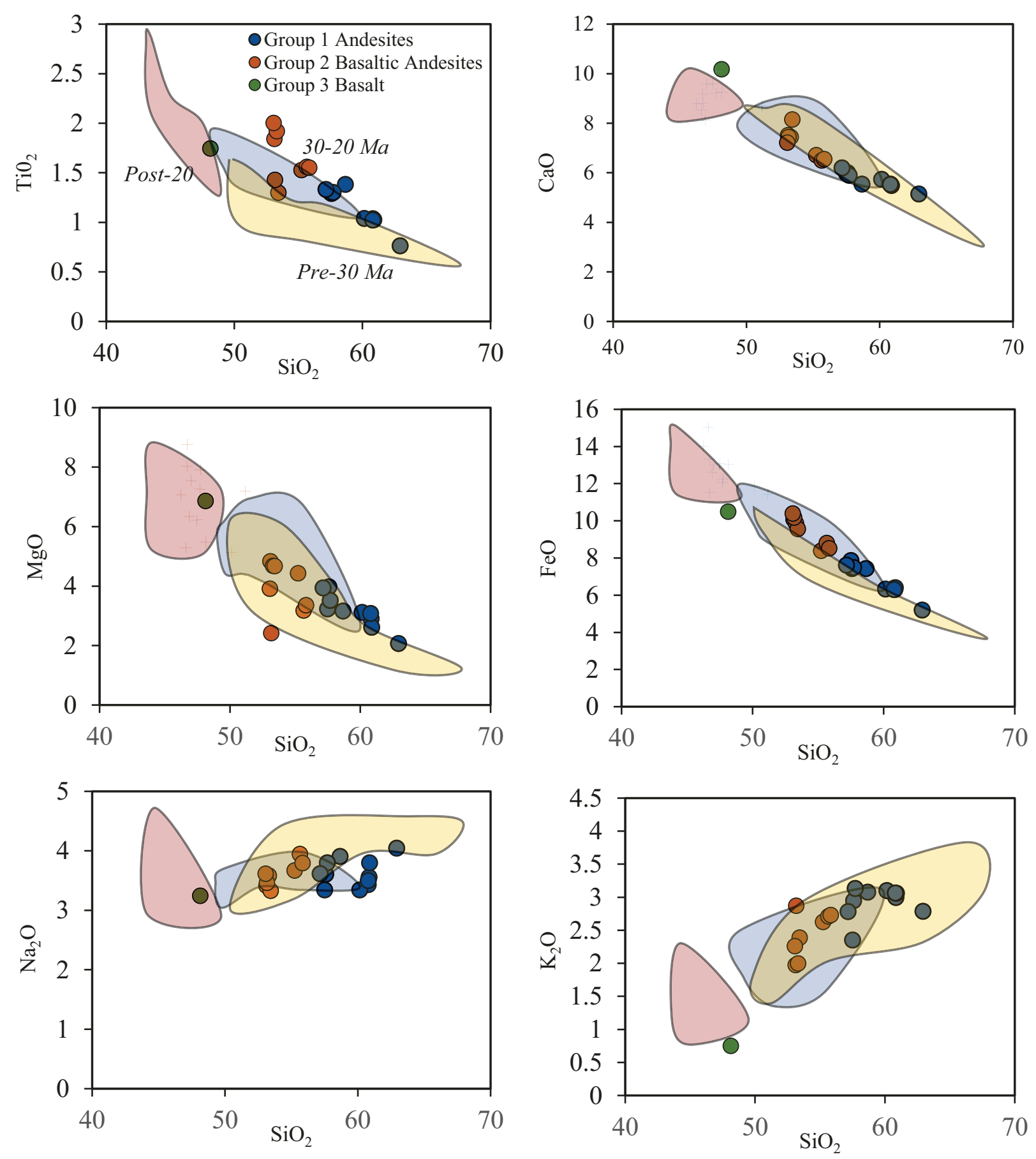

Figure 4. Selected major-element Harker diagrams for the BWA series overlaid on top of pre$30 \mathrm{Ma}$ (yellow), 30-20 Ma (blue), and post-20 Ma (red) volcanic rocks analyzed by Davis and Hawkesworth (1994, 1995). 
a)

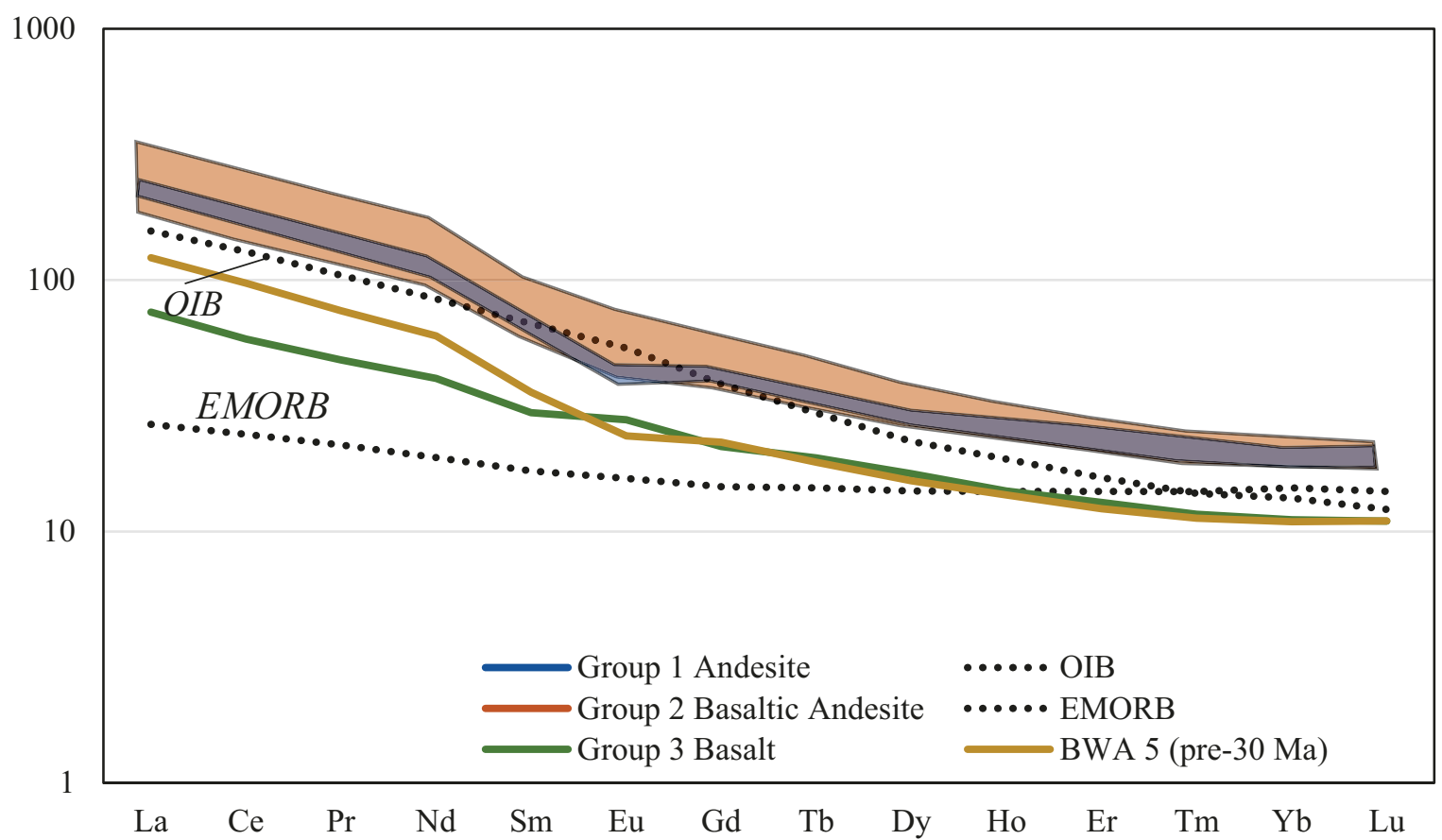

b) 1000

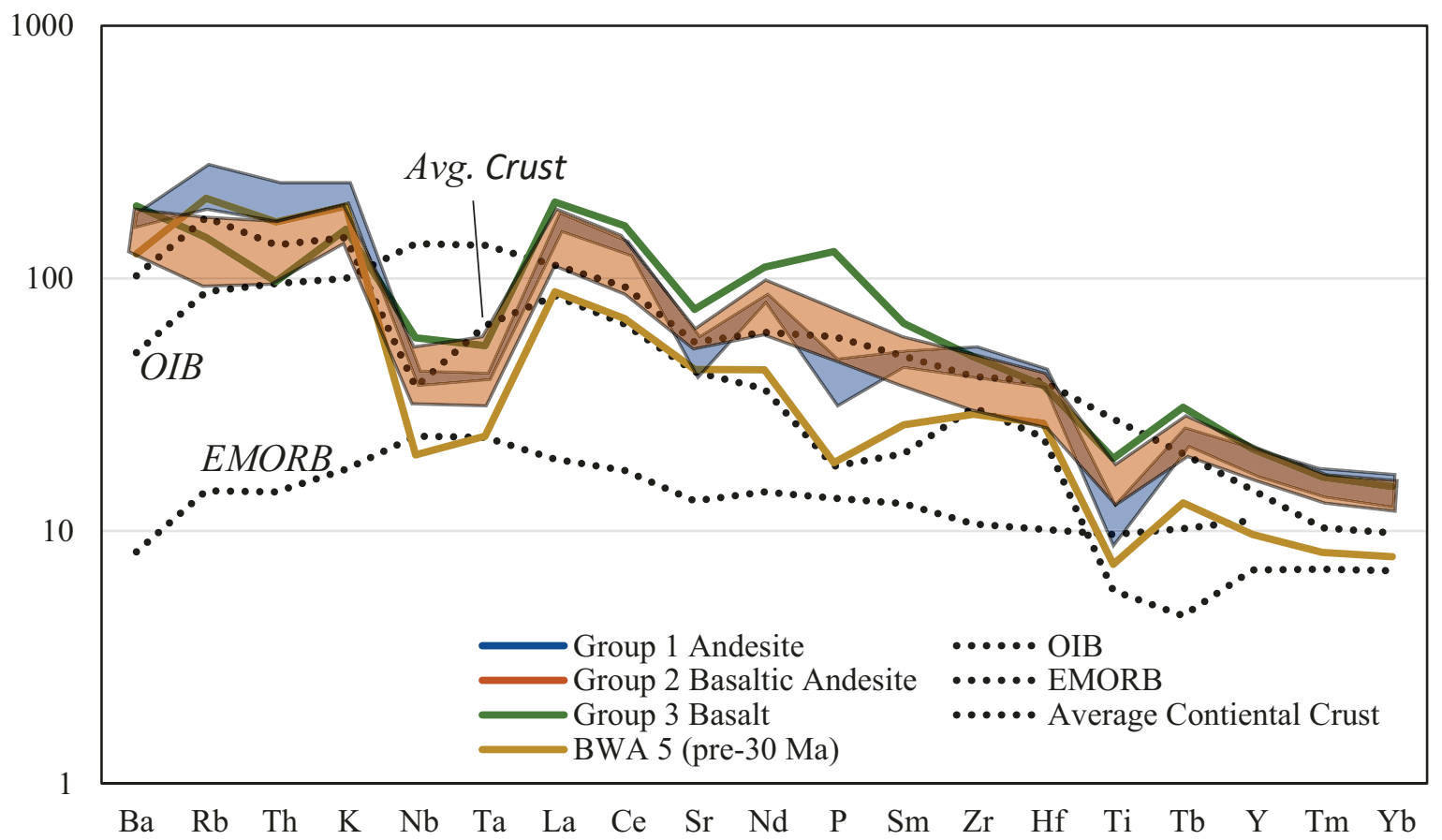

Figure 5. a) Chondrite-normalized rare-earth element (REE) patterns of the BWA series. b) Primitive mantle normalized multi-element diagram of the BWA series. EMORB and OIB compositions are taken from Sun and McDonough (1989). Average continental crust was taken from Rollinson (1993). The blue fields indicate group 1 andesites; the orange fields indicate group 2 basaltic andesites; the green lines indicates group 3 basalt; the yellow lines indicate BWA 5, likely to be from the pre-30 Ma Bear springs formation. 


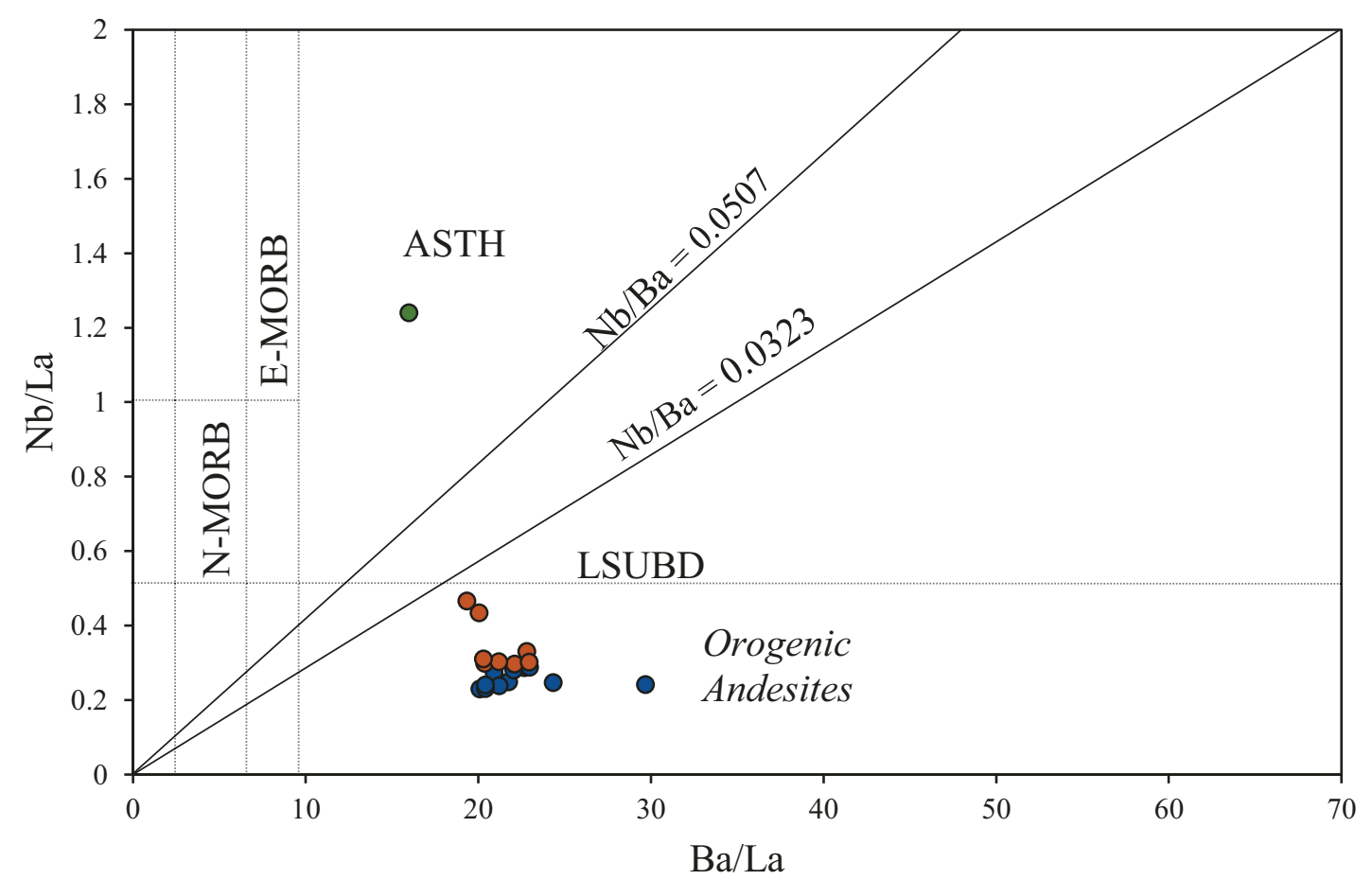

Figure 6. Trace-element diagnostic diagrams for the BWA series. ASTH: asthenosphere source; LSUBD: subduction-modified lithospheric source. $\mathrm{Nb} / \mathrm{Ba}$ boundaries taken from McMillan (1998). 
a)

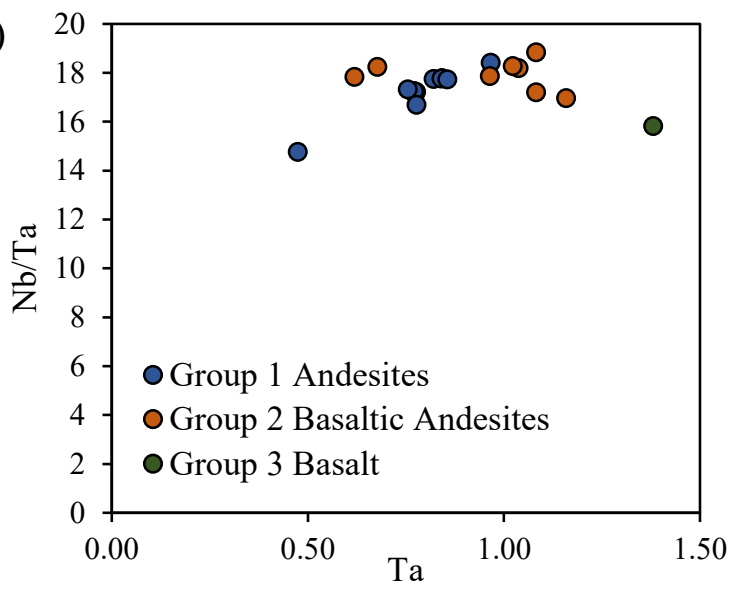

c)

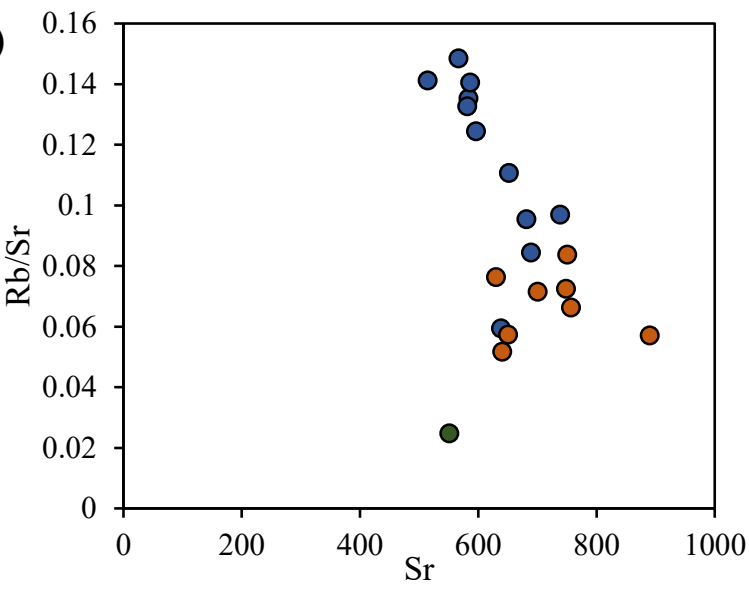

b)

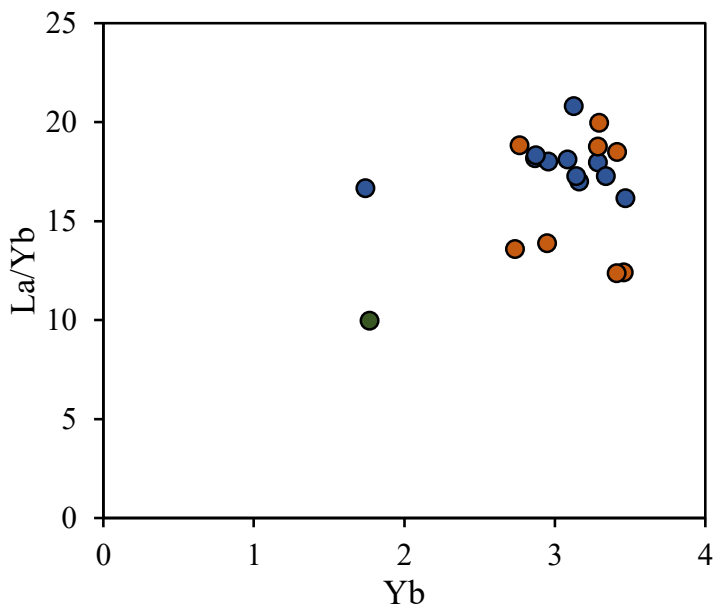

d)

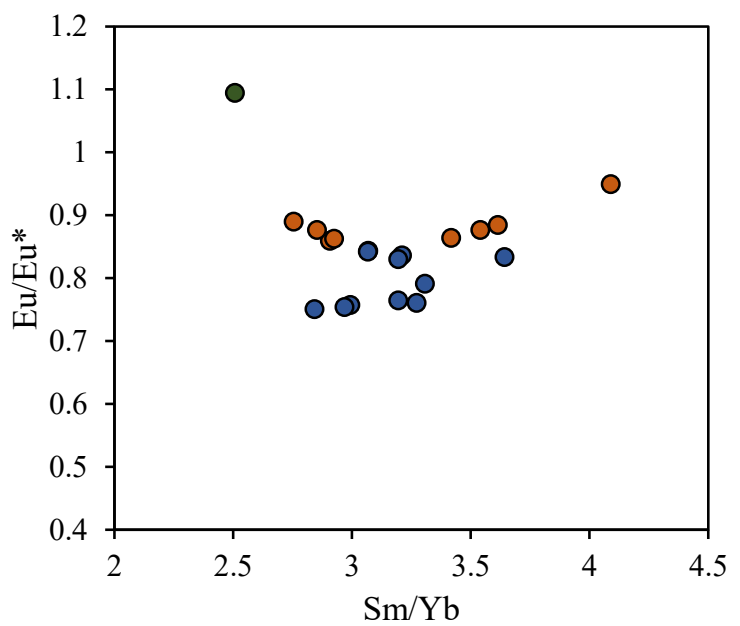

Figure 7. Bivariate trace-element plots: (a) $\mathrm{Nb} / \mathrm{Ta}$ versus $\mathrm{Ta}$; (b) $\mathrm{La} / \mathrm{Yb}$ versus $\mathrm{Yb}$; (c) $\mathrm{Rb} / \mathrm{Sr}$ versus $\mathrm{Sr} ;$ (d) $\mathrm{Eu} / \mathrm{Eu}^{*}$ versus $\mathrm{Sm} / \mathrm{Yb}$. 

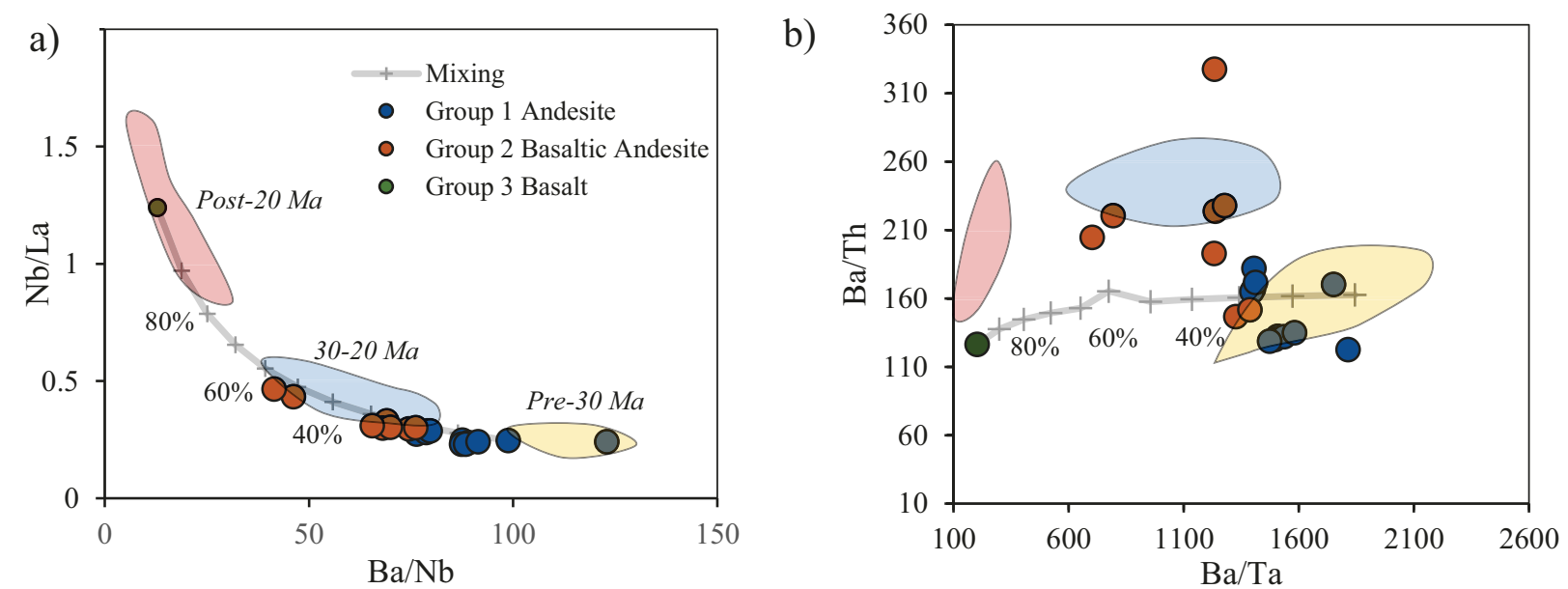

Figure 8. Calculated mixing models for the more evolved andesite, BWA 12, with the true basalt similar in composition to post-20 Ma rocks, BWA 30. a) The $\mathrm{Nb} / \mathrm{La}$ vs. Ba/ $\mathrm{Nb}$ mixing array shows that $30-55 \%$ of the basaltic magma is needed to reproduce the variation in the incompatible elements. b) The $\mathrm{Ba} / \mathrm{Th}$ vs. $\mathrm{Ba} / \mathrm{Ta}$ mixing array does not reproduce the trend within the BWA series and lies below the data points. 

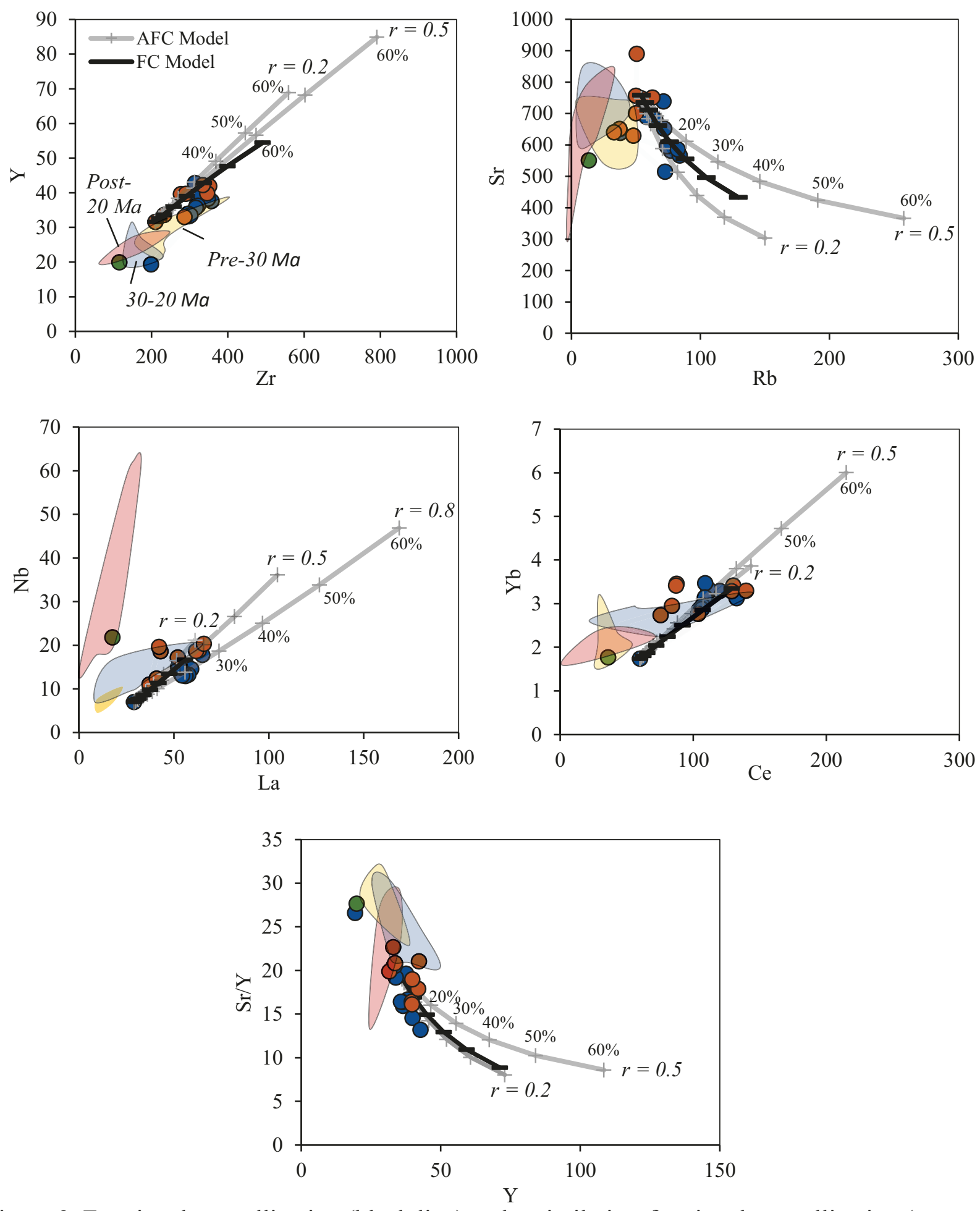

Figure 9. Fractional crystallization (black line) and assimilation-fractional crystallization (gray line) models of the BWA series. The starting compositions used are similar to pre-30 Ma rock (BWA 5) and were contaminated with average crustal material taken from Rollinson (1993). Fractionation was done at intervals of $10 \%$ with a range of $r$ values from 0.2 to 0.8 . Previously analyzed samples taken from Davis and Hawkesworth $(1994,1995)$ show pre-30 Ma (yellow), 30-20 Ma (blue), and post-20 Ma (red) rocks. 
a) $45-36.2$

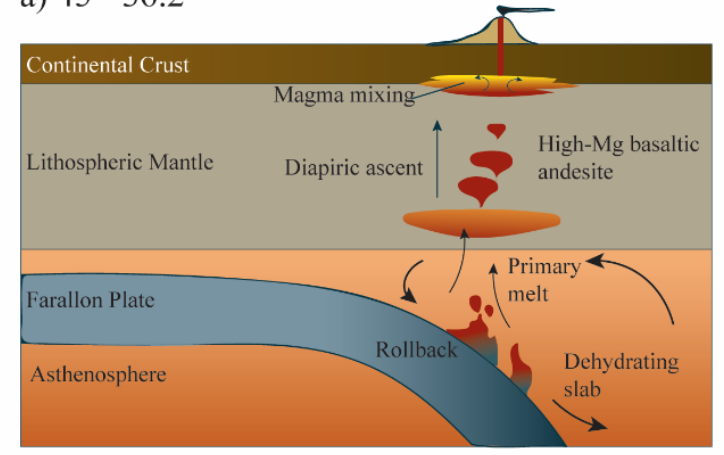

c) $26.6-23.1$

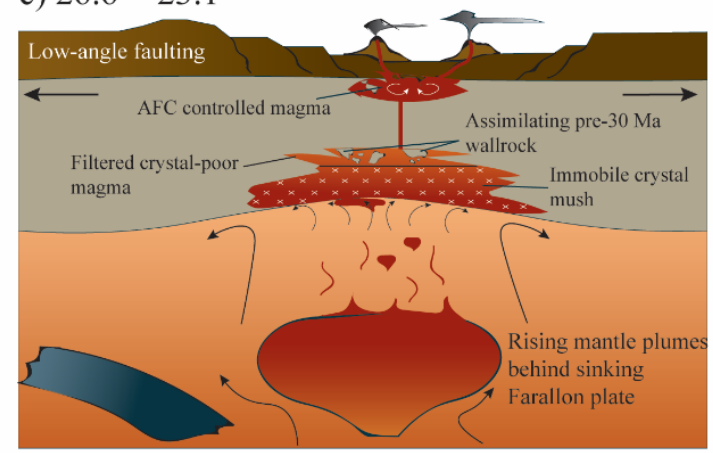

e) $20-10 \mathrm{Ma}$

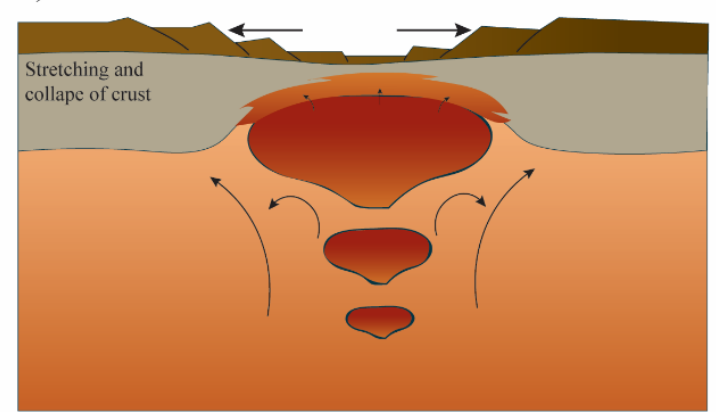

b) $36.2-28.5$

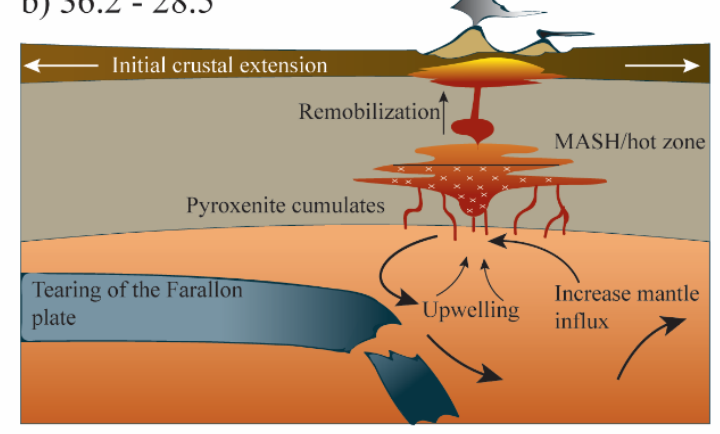

d) $23.1-21.4$

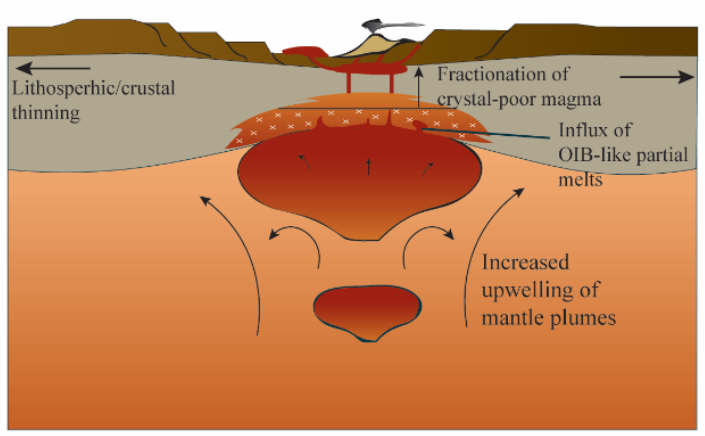

f) 10 - $0 \mathrm{Ma}$

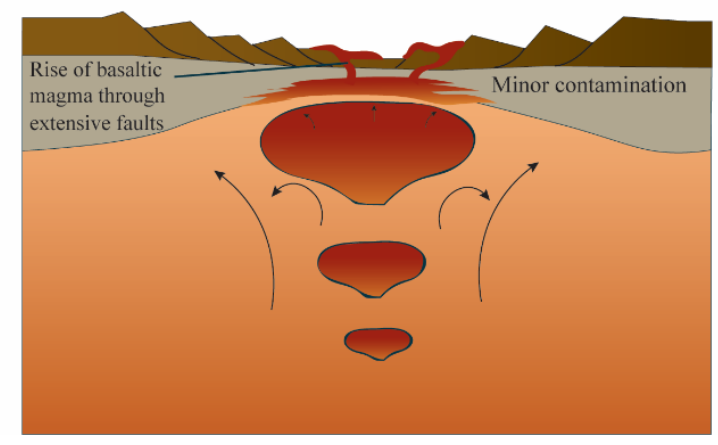

Figure 10. Suggested evolutionary stages in the development of magmatism within the MDVF (not to scale). a) Rollback and subsequent dehydration of the Farallon plate provides an influx of basaltic magma that underplates the lithospheric mantle. High-Mg basaltic andesite composition magma rise via diapirism to the lower crust $(\sim 5 \mathrm{kbar})$ and mixes with crustal melts. Eruption of fractionation controlled pyroxene andesites and hornblende dacites that make up the Rubio Peak Formation. b) The tectonic regime transitions from crustal shortening to ductile extension as the Farallon plate breaks apart and sinks into the mantle resulting in the upwelling of asthenosphere to form a large MASH/hot zone. Diapiric transport of basaltic magma rises to the lower crust and coalesces to produce a crystal mush that fuels caldera-forming eruptions of the ignimbrite flare-up and early erupted andesites of the Bear springs formation. c) Crustal extension continues after peak rifting at 28.5 Ma resulting in the thinning of the crust and decompression melting of the lithospheric mantle as mantle plumes drive deep magmatic processes. Accumulation of magma incorporates deep crustal signatures similar to pre-30 Ma 
rock through assimilation and fractional crystallization (AFC) as well as incorporating partial melts from residual rutile-bearing pyroxenites. The basaltic magma is likely in contact with an amphibole stable source and moves to a plagioclase stable source. During transportation to the lower crust, the extracted melt is compressed and filtered through a basaltic crystal-rich mush. The crystal-poor magma continues to evolve by AFC processes before ascending to the surface through deep conduits, producing the BWA. d) Thinning of the lithospheric mantle allows partial melts of the rising asthenosphere to mix with assimilating and fractionally crystallizing basaltic magma in the lower crust. These partial melts contribute a more OIB-like signature and transitions volcanism to more basaltic compositions. e) A hiatus in magmatism occurs between 20-10 Ma. (f) Extensional stress continues as the lithosphere cools. Upper crustal fractures transition into listric Basin and Range fault blocks. Basaltic magma rises through deep fractures from pockets of magmatic intrusions in the lithospheric mantle, imparting a strong OIB-like signature. 


\section{CONCLUSIONS}

During the mid- to late-Tertiary, the development of episodic large-scale caldera-forming eruptions with associated intermediate to mafic lava flows have significantly shaped the landscape of western North America. Understanding what initiated this event, the timeline of what was erupted, and the transition in the magmatic source has been deemed challenging and remains an ongoing effort to resolve. The multitude of factors that play a crucial role in the petrogenesis of these eruptions add to the complexity of this regional event and have been proven exceedingly difficult to explain through simple models.

The manuscripts presented here examine the magmatic evolution of western North America and its relation to the transition in tectonic regimes from crustal shortening to extension. With several contemporaneous volcanic fields erupting in western North America, this study focused on the Mogollon-Datil volcanic field (MDVF), located in southwestern New Mexico, to address the transition in volcanic activity from crystal-rich ignimbrite eruptions to basaltic lava flows, and to integrate the petrogenesis of the poorly recognized basaltic andesite to andesite lava flows that make up a large volume of the MDVF. Analysis of the Bearwallow Mountain Andesite (BWA) was used to reveal the gradual change in magma composition and the style of volcanism during the change in tectonic regimes (30-20 Ma) by attempting to answer two questions: 1) What is the geochemical diversity of the BWA? 2) What petrogenetic process(es) and magmatic source produced the crystal-poor intermediate composition lava flows of the BWA? Petrography, whole-rock major- and trace-element concentrations, and petrologic modeling methods provide evidence that the BWA was erupted from a subduction-modified

lithospheric mantle source that was contaminated by pre-30 Ma material through assimilation 
and fractional crystallization (AFC) processes and rapidly ascended to the Earth's surface via deep conduits/fractures.

The following conclusions can be made from this study:

1. The known cause of the ignimbrite flare-up is difficult to prove with explicit certainty, as demonstrated by the numerous tecto-magmatic models that exist to explain the genesis of magmatism. However, evidence concludes that the initiation of the ignimbrite flare-up was likely triggered after a prolonged period of flat slab subduction, in which the Farallon plate later rolled back to a steeper dip beneath the lithosphere, resulting in volcanism far inland from the western margin of North America. During what was likely considered a passive continental margin during the end of the Laramide orogeny, tearing of the subducting slab would produce the variations in the rate of rollback and the location of magma production. With the aid of early ductile extension, large amounts of basaltic magma would have been generated by dehydration of the sinking oceanic plate and thus lowering the solidus of the overlying lithospheric mantle to allow large-scale partial melts to develop (Best et al., 2016). Large accumulations of basaltic magma would have then further intruded into the overlying crust generating MASH/hot zones. Farmer et al. (2007) confirmed that sufficient magma would have been produced during the removal of the Farallon plate based on mantle source volume calculations. The subsequent ignimbrite eruptions would have been controlled by the variations in thickness, temperature, and composition of the crust as the tectonic regimes transition to intercontinental extension.

2. Using $\mathrm{Sr} / \mathrm{Y}$ and $(\mathrm{La} / \mathrm{Yb})_{\mathrm{N}}$ coupled with $\mathrm{Nb} / \mathrm{Ta}$ and $(\mathrm{Dy} / \mathrm{Yb})_{\mathrm{N}}$ ratios to model changes in crustal thicknesses in southwestern New Mexico, it appears reasonable to conclude that the continental crust was thickest at $\sim 36 \mathrm{Ma}$, coinciding with the initiation of the ignimbrite flare-up, and later underwent a dramatic thinning event between 32 and 28 Ma. This change in crustal thickness may provide a realistic model for the transition in magmatism from intermediate compositions (50-36 Ma) to bimodal compositions (36-28 Ma), followed by a progressive change to basaltic magmatism (28-0 Ma).

3. The Bearwallow Mountain Andesite (BWA) is crystal-poor relative to earlier erupted andesites and dacites and consists primarily of pyroxene, and olivine phenocrysts within a plagioclase-rich groundmass. The absence of plagioclase phenocrysts in the basaltic andesite lavas suggests that differentiation occurred at depths greater than 30 $\mathrm{km}$. Texturally, the majority of the BWA shows no signs of disequilibrium or inclusions of foreign material (i.e. xenocrysts, xenoliths, glomerocrysts), indicating no petrographic evidence for magma mixing.

4. Based on major- and trace-element compositions, the BWA can be classified into three groups: (1) andesite-trachyandesite $\left(57-63 \mathrm{wt} \% \mathrm{SiO}_{2}\right) ;(2)$ basaltic andesitebasaltic trachyandesite $\left(52-57 \mathrm{wt} \% \mathrm{SiO}_{2}\right)$; (3) basalt ( $\left.48 \mathrm{wt} \% \mathrm{SiO}_{2}\right)$. Group 1 shows an "arc-like" trace-element signature and has the highest enrichment of incompatible 
elements with respect to HFSE along with strong negative anomalies of $\mathrm{Nb}-\mathrm{Ta}$ and $\mathrm{Ti}$ contents. Group 2 is similar to group 1 and shows a similar "arc-like" trace-element signature but has relatively higher concentrations of compatible elements $(\mathrm{Ni}=\sim 78)$. Group 3 shows an OIB-like trace-element signature indicated by enrichment in more compatible elements $(\mathrm{Ni}=88 \mathrm{ppm}, \mathrm{V}=213 \mathrm{ppm})$, thus producing low LILE/HFSE $(\mathrm{Ba} / \mathrm{Nb})$ and LREE/HFSE $(\mathrm{La} / \mathrm{Nb})$ ratios.

5. Using tectonic discriminatory diagrams, both groups 1 and 2 BWA lavas are classified as calc-alkaline "orogenic" and source from a subduction-modified lithosphere (McMillan, 1998). Group 3 is classified as "within-plate basalt" derived from the asthenosphere and is consistent with EM-type OIB trace-element ratios (Pearce and Cann, 1973; Pearce, 1982; Sun and McDonough, 1989).

6. Trace-element compositions (REEs, Dy/Yb, Dy/Dy*) suggest an amphibole stable source, remnant from pre-30 Ma andesites and dacites, during initial stages of differentiation, imparting "cryptic" signatures in the groundmass of BWA lavas. $\mathrm{La} / \mathrm{Yb}$ and $\mathrm{Hf} / \mathrm{Sm}$ ratios support garnet instability at the source, thus favoring fractionation of amphibole and plagioclase at depth. Unusually high $\mathrm{Nb} / \mathrm{Ta}$ ratios also suggest that partial melting of deep-seated pyroxenites (arclogites) may have played a role in the genesis of BWA magmas during crustal thinning and mantle upwelling.

7. Petrologic modeling and petrography concludes that the BWA was formed from AFC processes rather than magma mixing. Mixing between parental BWA magma, similar to pre-30 Ma rock compositions (BWA 5), with compositions similar to post-20 Ma rocks (BWA 30), produced mixing trends that did not fit the BWA dataset (Fig. 8b). Fractional crystallization alone, without contamination, fit the BWA data set relatively well, however, it required a significant amount of fractionation to reproduce the andesite compositions. Therefore, the AFC model produced the best fit and proved to be the most realistic scenario to explain the petrogenesis of the BWA magmas. The rate of crustal contamination was shown to be low to moderate, with the r-values ranging between 0.2-0.5. The BWA magmas were suggested to have gone through several stages of assimilation, both in the lithospheric mantle to acquire trace-element compositions similar to pre-30 Ma material, and in the lower crust to further differentiate the BWA magmas to basaltic andesite to andesite compositions.

8. The crystal-poor nature of the BWA is suggested to have evolved from filtering of the magma through an immobile crystal-rich mush. This would have removed the majority of the phenocryst phases of the melt before eruption, and thus producing aphyric textured rocks with minor crystalline phases of plagioclase, pyroxene, and olivine. The progressive extension of the continental crust would have allowed this crystal-poor melt to rapidly rise to the surface through deep conduits and fractures within the crust, minimizing the time for crystallization.

9. Integrating the genesis of the large-volume intermediate to mafic rocks into the volcanic history of the MDVF, they appear fit more of a subduction-related heritage and later progress to an OIB-modified source triggered by continued extension. The 
"arc-like" signatures within these basaltic andesites to andesites may not have derived from the flat-subduction of the Farallon plate, but an earlier subduction event (Davis et al., 1993). Further investigation is needed to determine the exact source of the arc signature. The petrogenesis of the BWA andesites are atypical of intermediate magma generation where magma mixing and hybridization predominate. Instead, fractional crystallization controls magma generation with progressive contamination of wall rock material through assimilation. Magma mixing only becomes apparent during the later stages of basaltic andesite genesis, in which partial melts of OIBmodified lithospheric mantle mix with the assimilating BWA magmas. 


\section{FULL REFERENCES CITED LIST}

Best, M.G., Christiansen, E.H., de Silva, S., and Lipman, P.W., 2016, Slab-rollback ignimbrite flareups in the southern Great Basin and other Cenozoic American arcs: A distinct style of arc volcanism: Geosphere, v. 12, no. 4, p. 1097-1135, doi:10 .1130/GES01285.1.

Davis, J.M., Elston, W.E., and Hawkesworth, C.J., 1993, Basic and intermediate volcanism of the Mogollon-Datil volcanic field: implications for mid-Tertiary tectonic transitions in southwestern New Mexico, USA: Geological Society, London, Special Publications, v. 76, no. 1, p. 469-488, doi:10.1144/gsl.sp.1993.076.01.25.

Davis, J.M., and Hawkesworth, C.J., 1995, Geochemical and tectonic transitions in the evolution of the Mogollon-Datil volcanic field, New Mexico, U.S.A.: Chemical Geology, v. 119, p. $31-53$.

de Silva, S.L., Zandt, G., Trumbull, R., Viramonte, J.G., Salas, G., and Jimenez, N., 2006, Large ignimbrite eruptions and volcano-tectonic depressions in the Central Andes: A thermomechanical perspective, in Troise, C., de Natale, G., and Kilburn, C.R.J., eds., Mechanisms of Activity and Unrest at Large Calderas: Geological Society of London Special Publication 269, p. 47-63, doi:10.1144/GSL.SP.2006.269.01.04.

Farmer, L.G., Bailley, T., Elkins-Tanton, L.T., 2007, Mantle source volumes and the origin of the mid-tertiary ignimbrite flare-up in the southern Rocky Mountains, western U.S.: Lithos, v. 102, p. 279-294.

Johnson, C.M., 1991, Large-scale crust formation and lithosphere modification beneath middle to late Cenozoic calderas and volcanic fields, western North America: Journal of Geophysical Research, v. 96, p. 13,485-13,507, doi:10.1029/91JB00304.

Lipman, P.W., Prostka, H.J., and Christiansen, R.L., 1972, Cenozoic volcanism and plate tectonic evolution of western United States: Part 1. Early and middle Cenozoic: Philosophical Transactions of the Royal Society of London, v. 271, p. 217-248, doi:10.1098/rsta.1972.0008.

McIntosh, W.C., Chapin, C. E., Ratté, J.C., and Sutter, J. F., 1992, Time-stratigraphic framework for the Eocene-Oligocene Mogollon-Datil volcanic field, southwest New Mexico: Geological Society of America Bulletin, v. 104, no. 7, p. 851-871.

McMillan, N.J., 1998, Temporal and spatial magmatic evolution of the Rio Grande rift, in Mack, G.H., Austin, G.S., and Barker, J.M., eds., Las Cruces Country II: New Mexico Geological Society 49th Annual Fall Field Conference Guidebook, p. 107-116.

Pearce, J.A., and Cann, J.R., 1973, Tectonic setting of basic volcanic rocks determined using trace element analyses: Earth and Planetary Science Letters, v. 19, p. 290-300. 
Pearce, J.A., 1982, Trace element characteristics of lavas from destructive plate boundaries, in Thorpe, R.S., ed., Andesites: Orogenic Andesites and Related Rocks, John Wiley and Sons, p. 252-548.

Sun and McDonough, 1989, Chemical and isotopic systematics of oceanic basalts: implication for mantle composition and processes, in Saunder, A.D., Norry, M.J., ed., Magmatism in the ocean basins: Geological Society, London, Special Publications, v. 42, p. 313-345. 